Prepared in cooperation with the U.S. Army Corps of Engineers

\title{
A Multi-Year Analysis of Spillway Survival for Juvenile Salmonids as a Function of Spill Bay Operations at McNary Dam, Washington and Oregon, 2004-09
}

Open-File Report 2012-1125 



\section{A Multi-Year Analysis of Spillway Survival for Juvenile Salmonids as a Function of Spill Bay Operations at McNary Dam, Washington and Oregon, 2004-09}

By Noah S. Adams, Hal C. Hansel, Russell W. Perry, and Scott D. Evans

Prepared in cooperation with the U.S. Army Corps of Engineers

Open-File Report 2012-1125

U.S. Department of the Interior

U.S. Geological Survey 


\section{U.S. Department of the Interior \\ KEN SALAZAR, Secretary}

\section{U.S. Geological Survey \\ Marcia K. McNutt, Director}

U.S. Geological Survey, Reston, Virginia: 2012

For more information on the USGS-the Federal source for science about the Earth, its natural and living resources, natural hazards, and the environment, visit http://www.usgs.gov or call 1-888-ASK-USGS.

For an overview of USGS information products, including maps, imagery, and publications, visit http://www.usgs.gov/pubprod

To order this and other USGS information products, visit http://store.usgs.gov

Any use of trade, product, or firm names is for descriptive purposes only and does not imply endorsement by the U.S. Government.

Although this report is in the public domain, permission must be secured from the individual copyright owners to reproduce any copyrighted material contained within this report.

Suggested citation:

Adams, N.S., Hansel, H.C., Perry, R.W., and Evans, S.D., 2012, A multi-year analysis of spillway survival for juvenile salmonids as a function of spill bay operations at McNary Dam, Washington and Oregon, 2004-09: U.S. Geological Survey Open-File Report 2012-1125, 68 p. 


\section{Contents}

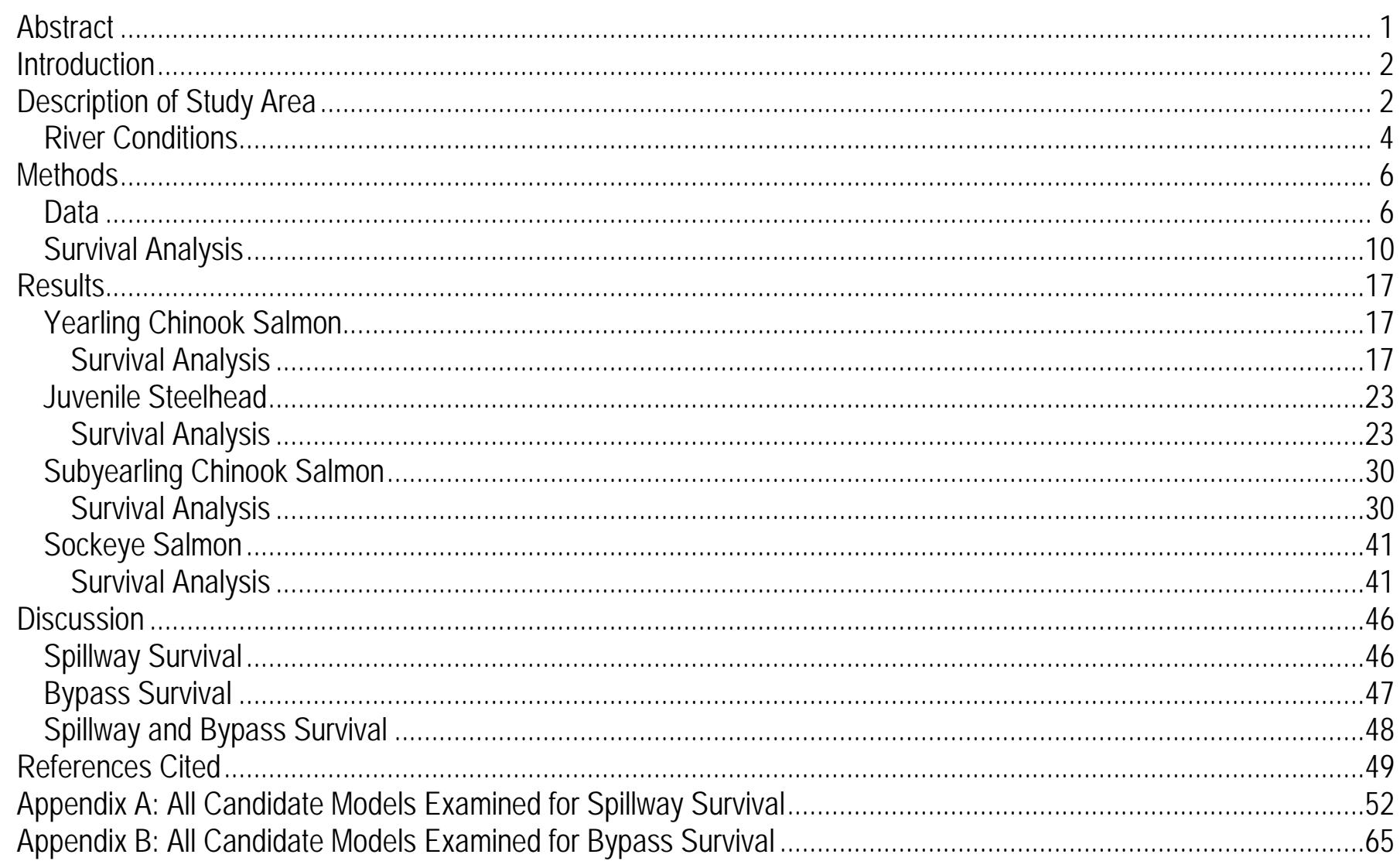

\section{Figures}

Figure 1. Map showing location of McNary Dam andother major hydroelectric projects on the Columbia and Snake Rivers, Washington and Oregon.

Figure 2. Hydrograph of mean daily project outflow during radio and acoustic telemetry study dates at McNary Dam, 2004-09, and the 10-year average, 2000-09.

Figure 3. Hydrograph of mean daily project spill during radio and acoustic telemetry study dates at McNary Dam, 2004-09, and the ten year average, 2000-09

Figure 4. Hydrograph of mean daily water temperature of the Columbia River at McNary Dam during radio and acoustic telemetry study dates, 2004-09, and the 10-year average, 2000-2009.

Figure 5. Percentage of spill discharge for each spill pattern during spring (a) and summer (b) study periods at McNary Dam, 2004-09.

Figure 6. Schematic of the mark-recapture model used to estimate survival (ø) and detection probabilities $(p)$ of juvenile salmonids passing through McNary Dam for releases during 2004-09.....

Figure 7. Survival of yearling Chinook salmon that passed through conventional spill bays (black plot) and the TSWs (gray plot) at McNary Dam in relation to spill bay discharge, 2004-09 .

Figure 8. Spillway survival of yearling Chinook salmon in relation to total discharge for each spill pattern at McNary Dam, 2004-09.

Figure 9. Spillway survival of juvenile steelhead in relation to spillway discharge at McNary Dam, 2004-09 
Figure 10. Spillway survival of juvenile steelhead in relation to total discharge for each spill pattern at McNary Dam, 2004-09.

Figure 11. Spillway survival of subyearling Chinook salmon in relation to percent spill for each spill pattern at McNary Dam, 2004-09

Figure 12. Spillway survival of subyearling Chinook salmon in relation to total discharge for each spill pattern at McNary Dam, 2004-09

Figure 13. Spillway survival of subyearling Chinook salmon in relation to total discharge for each spill pattern at McNary Dam, 2004-09

Figure 14. Bypass survival of subyearling Chinook salmon in relation to total discharge, with an interaction between spill pattern and total discharge, for each spill pattern at McNary Dam, 2004-09....

Figure 15. Bypass survival of subyearling Chinook salmon in relation to water temperature at McNary Dam, 2004-09

Figure 16. Spillway survival of sockeye salmon in relation to spillway discharge for each spillway passage location at McNary Dam, 2004-09... 44

Figure 17. Spillway survival of sockeye salmon in relation to total discharge for each spillway passage location at McNary Dam, 2004-09.

\section{Tables}

Table 1. Sample sizes of fish used in this analysis that passed through theMcNary Damspillway or bypass, 2004-09.

Table 2. Specifications of transmitters surgically implanted in juvenile salmonids, 2006-09.....

Table 3. Summary statistics of fork length and weight of acoustic-tagged juvenile salmonids released in the Columbia River, by release site, 2006-09.

Table 4. Number of acoustic-tagged juvenile salmonids released in the Columbia River, number (and percentage of those released) that passed McNary Dam through any route, range of passage dates, and corresponding percentage spill of total project discharge over dates of passage at McNary Dam, by species, 2006-09.

Table 5. List of variables used in survival analyses of fish passing the McNary Dam spillway and bypass, 2004-09.

Table 6. Yearly resolution of spill bay passage location, Temporary Spillway Weir placement (T), and lateral division.

Table 7. Model selection results based on varying $\lambda$ and $p$ with respect to year for yearling Chinook salmon, 2004-09.

Table 8. Model selection for fish that passed through the spillway at McNary Dam relating survival $(\varnothing)$ as a function of individual and group covariates using the fixed structure of the best model for $p$ and $\lambda$ parameters for yearling Chinook salmon, 2004-09.....

Table 9. Slope (Beta) coefficients, standard error, and 95-percent confidence limits of model parameters for yearling Chinook salmon passing McNary Dam, 2004-09.

Table 10. Model selection for fish that passed through the juvenile bypass system outfall at McNary Dam relating survival $(\varnothing)$ as a function of individual and group covariates using the fixed structure of the best model for $p$ and $\lambda$ parameters for yearling Chinook salmon, 2004-09.

Table 11. Model selection results based on varying $\lambda$ and $p$ with respect to year for juvenile steelhead at McNary Dam, 2004-09. 
Table 12. Model selection for fish that passed through the spillway at McNary Dam relating survival $(\varnothing)$ as a function of individual and group covariates using the fixed structure of the best model for $p$ and $\lambda$ parameters for juvenile steelhead, 2004-09.

Table 13. Slope (Beta) coefficients, standard error, and 95-percent confidence limits of model parameters for juvenile steelhead passing McNary Dam, 2004-09.

Table 14. Model selection for fish that passed through the juvenile bypass system outfall at McNary Dam relating survival ( $\varnothing)$ as a function of individual and group covariates using the fixed structure of the best model for $p$ and $\lambda$ parameters for juvenile steelhead, 2004-09

Table 15. Model selection results based on varying $\lambda$ and $p$ with respect to year for subyearling Chinook salmon, 2004-09.....

Table 16. Model selection for fish that passed through the spillway at McNary Dam relating survival ( $\varnothing$ ) as a function of individual and group covariates using the fixed structure of the best model for $p$ and $\lambda$ parameters for subyearling Chinook salmon, 2004-09

Table 17. Slope $(\beta)$ coefficients, standard error, and 95-percent confidence limits of model parameters for subyearling Chinook salmon passing McNary Dam, 2004-09

Table 18. Model selection for fish that passed through the juvenile bypass system outfall at McNary Dam relating survival $(\varnothing)$ as a function of individual and group covariates using the fixed structure of the best model for $p$ and $\lambda$ parameters for subyearling Chinook salmon, 2004-09.

Table 19. Model selection results for sockeye salmon passing through the spillway based on varying $\lambda$ and $p$ with respect to year, 2004-09.

Table 20. Model selection for fish that passed through the spillway at McNary Dam relating survival (ø) as a function of individual and group covariates using the fixed structure of the best model for $p$ and $\lambda$ parameters for sockeye salmon, 2004-09

Table 21. Slope $(\beta)$ coefficients, standard error, and 95-percent confidence limits of model parameters for sockeye salmon passing through the spillway at McNary Dam, 2004-09 


\section{Conversion Factors, Datums, Abbreviations, and Acronyms}

\section{Conversion Factors}

Inch/Pound to SI

\begin{tabular}{llll}
\hline \multicolumn{1}{c}{ Multiply } & By & To obtain \\
\hline cubic foot per second $\left(\mathrm{ft}^{3} / \mathrm{s}\right)$ & Flow rate & \\
\hline Multiply & 0.02832 & cubic meter per second $\left(\mathrm{m}^{3} / \mathrm{s}\right)$ \\
\hline SI to Inch/Pound & By & To obtain \\
\hline Length & & \\
\hline kilometer $(\mathrm{km})$ & 3.281 & foot (ft) & \\
\hline & 0.6214 & mile (mi) & \\
\hline gram $(\mathrm{g})$ & Mass & & \\
\hline
\end{tabular}

Temperature in degrees Celsius $\left({ }^{\circ} \mathrm{C}\right)$ may be converted to degrees Fahrenheit $\left({ }^{\circ} \mathrm{F}\right)$ as follows:

${ }^{\circ} \mathrm{F}=\left(1.8 \times{ }^{\circ} \mathrm{C}\right)+32$.

\section{Datums}

Horizontal coordinate information is referenced to the World Geodetic System of 1984 (WGS 84).

Vertical coordinate information is referenced to the National Geodetic Vertical Datum of 1929 (NGVD 29).

\section{Abbreviations and Acronyms}

$\begin{array}{ll}\text { AIC } & \text { Akaike's Information Criterion } \\ \text { CJS } & \text { Cormack-Jolly-Seber models } \\ \text { Kcfs } & 1,000 \mathrm{ft}^{3} / \mathrm{s} \\ \text { PIT } & \text { passive integrated transponder } \\ \text { rkm } & \text { river kilometer } \\ \text { TSW } & \text { temporary spillway weir }\end{array}$




\title{
A Multi-Year Analysis of Spillway Survival for Juvenile Salmonids as a Function of Spill Bay Operations at McNary Dam, Washington and Oregon, 2004-09
}

\author{
By Noah S. Adams, Hal C. Hansel, Russell W. Perry, and Scott D. Evans
}

\begin{abstract}
We analyzed 6 years (2004-09) of passage and survival data collected at McNary Dam to examine how spill bay operations affect survival of juvenile salmonids passing through the spillway at McNary Dam. We also examined the relations between spill bay operations and survival through the juvenile fish bypass in an attempt to determine if survival through the bypass is influenced by spill bay operations. We used a Cormack-Jolly-Seber release-recapture model (CJS model) to determine how the survival of juvenile salmonids passing through McNary Dam relates to spill bay operations.

Results of these analyses, while not designed to yield predictive models, can be used to help develop dam-operation strategies that optimize juvenile salmonid survival. For example, increasing total discharge typically had a positive effect on both spillway and bypass survival for all species except sockeye salmon (Oncorhynchus nerka). Likewise, an increase in spill bay discharge improved spillway survival for yearling Chinook salmon (Oncorhynchus tshawytscha), and an increase in spillway discharge positively affected spillway survival for juvenile steelhead (Oncorhynchus mykiss). The strong linear relation between increased spill and increased survival indicates that increasing the amount of water through the spillway is one strategy that could be used to improve spillway survival for yearling Chinook salmon and juvenile steelhead. However, increased spill did not improve spillway survival for subyearling Chinook salmon and sockeye salmon. Our results indicate that a uniform spill pattern would provide the highest spillway survival and bypass survival for subyearling Chinook salmon. Conversely, a predominantly south spill pattern provided the highest spillway survival for yearling Chinook salmon and juvenile steelhead. Although spill pattern was not a factor for spillway survival of sockeye salmon, spill bay operations that optimize passage through the north and south spill bays maximized spillway survival for this species. Bypass survival of yearling Chinook salmon could be improved by optimizing conditions to facilitate bypass passage at night, but the method to do so is not apparent from this analysis because photoperiod was the only factor affecting bypass survival based on the best and only supported model. Bypass survival of juvenile steelhead would benefit from lower water temperatures and increased total and spillway discharge. Likewise, subyearling Chinook salmon bypass survival would improve with lower water temperatures, increased total discharge, and a uniform spill pattern.
\end{abstract}




\section{Introduction}

As juvenile salmon Oncorhynchus spp. and steelhead O. mykiss migrate downriver to the ocean, they are subject to natural and human-induced mortality. Predators contribute to total natural mortality along with other factors (Vigg and others, 1991; Collis and others, 2001). Impoundments caused by hydroelectric dams on the Snake and Columbia Rivers may indirectly contribute to mortality by slowing the migration of juvenile salmonids (Raymond, 1968, 1979; Plumb and others, 2006), thereby increasing energy expenditure during migration and allowing greater opportunity for predation. Further, passage through dams can be a major source of direct mortality (Mesa 1994; Whitney and others, 1997) that is cumulative for populations negotiating multiple dams.

Studies monitoring fish movements near McNary Dam were conducted annually from 2004 to 2009 to assess how dam operations or fish passage structures influence passage and survival of juvenile salmonids migrating through the hydroelectric system in a particular year. Although the McNary Dam studies provided valuable information for developing management strategies, some important questions remain unanswered. Managers often are interested in understanding how rates of survival and passage vary with environmental conditions, such as total river discharge or distribution of discharge across possible passage routes. Consistently similar conditions are favorable when the goal is point estimation under a given condition, but understanding how survival or passage varies in response to dam operations requires data for a wide range of conditions. Studies conducted in a single year will only consider a narrow range of environmental conditions, due to natural year-to-year variation in the environment. Multi-year analyses are better suited for the development of quantitative relationships than single-year analyses, because operational and environmental variation typically will be higher over a period of 5-10 years than within any given year. Furthermore, multi-year analyses benefit from the large sample sizes over multiple years, which can reduce statistical uncertainty and help identify relations that otherwise might be statistically undetectable. We analyzed 6 years (2004-09) of passage and survival data collected at McNary Dam to examine how spill bay operations affect survival of juvenile salmonids passing through the spillway at McNary Dam. In addition, we examined relations between spill bay operations and survival through the juvenile fish bypass in an attempt to determine if survival through the bypass is influenced by spill bay operations.

\section{Description of Study Area}

McNary Dam is the fourth dam on the Columbia River (counting upriver from its terminus with the Pacific Ocean) located 470 river kilometers (rkm) upriver from the Pacific Ocean and $52 \mathrm{rkm}$ downriver from the confluence of the Columbia and Snake Rivers (fig. 1). The reservoir formed by McNary Dam (Lake Wallula) extends 98 rkm upriver to the Hanford Reach of the Columbia River, and impounds 16 rkm of the Snake River downstream of Ice Harbor Dam. John Day Dam is located 123 rkm downriver of McNary Dam and creates Lake Umatilla. Our study area extended from Hat Rock State Park, Oregon, 10 rkm upriver of McNary Dam, to Sundale, Washington, 92 rkm downstream of McNary Dam, where our last acoustic telemetry array was located. 
McNary Dam is oriented perpendicular to the river channel and includes a navigation lock, spillway, powerhouse, and earthen dam. The spillway is $399 \mathrm{~m}$ long with 22 vertical lift-type spill gates that regulate discharge through the dam. The spillway discharges water at the ogee crest approximately $14 \mathrm{~m}$ below the water surface. During the sampling seasons in 2007-09, temporary spillway weirs (TSWs) were installed as part of a strategy to improve fish passage at the dam.

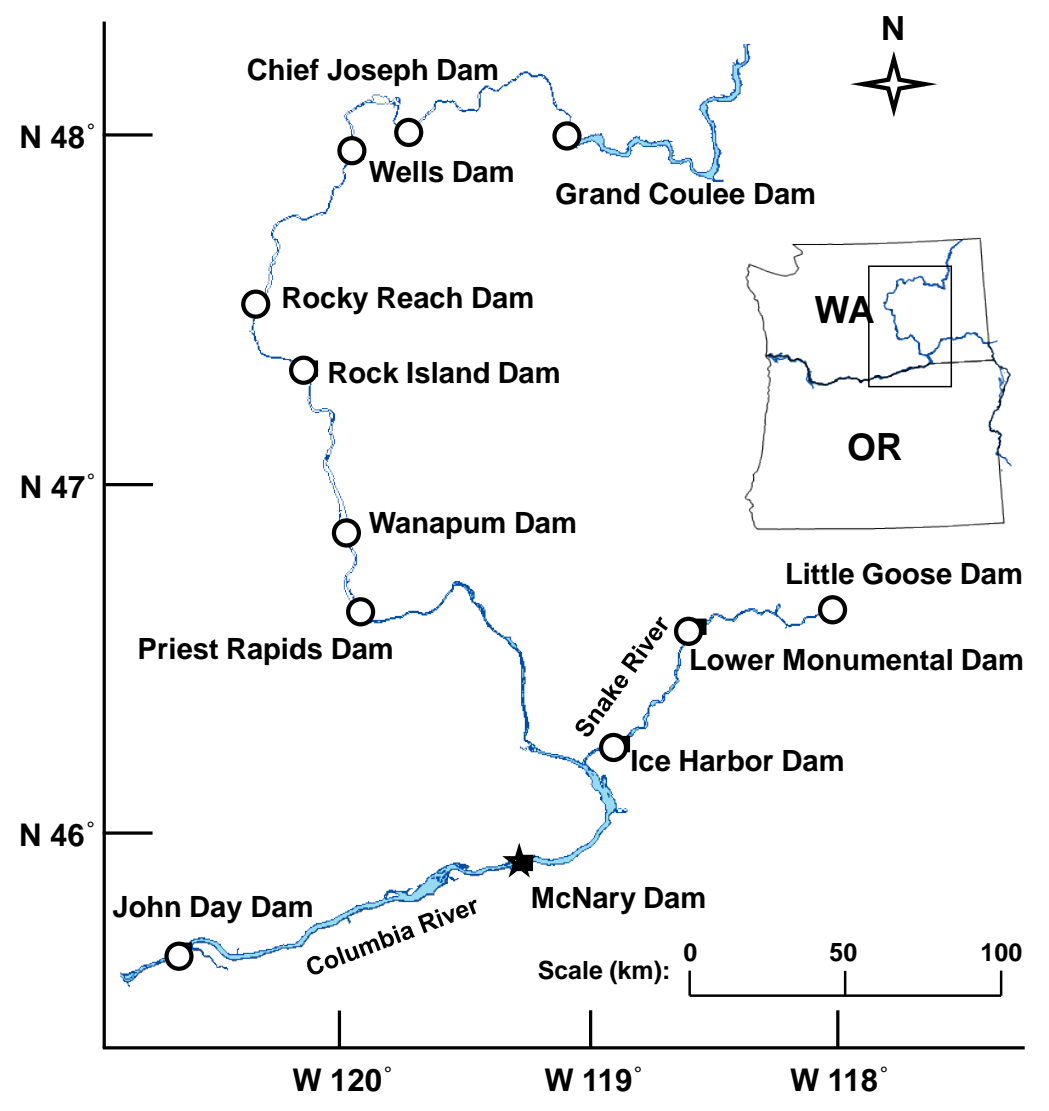

Figure 1. Map showing location of McNary Dam and other major hydroelectric projects on the Columbia and Snake Rivers, Washington and Oregon. 


\section{River Conditions}

Average daily discharge throughout a season was variable depending upon year. The 10-year average (2000-2009) in mid-April was about $210 \mathrm{kcfs}$, with discharge increasing to greater than 250 kcfs by late May (fig. 2). River-flows for the 10-year average decreased through June and July to less than 150 kcfs by August. Average daily spill at McNary Dam from 2000 to 2009 followed a similar trend to mean daily outflow (fig. 3). Mean daily spill in mid-April, at the start of the season, averaged $80 \mathrm{kcfs}$ and peaked in late May or early June at $125 \mathrm{kcfs}$ for the 10-year average. During 2004 and 2005, flow through the dam was low compared to the 10-year average. In 2004, very little flow was discharged through the spillway during the summer season. More detailed information regarding average daily discharge, including how discharge varied during the day and night periods, can be found in the annual reports of research (Perry and others, 2006, 2007; Adams and others, 2008; Adams and Counihan, 2009; Adams and Liedtke, 2009, 2010).

Water temperature steadily increased during the study period, from $9^{\circ} \mathrm{C}$ in April to a peak of about $21^{\circ} \mathrm{C}$ in late July or early August (fig. 4). Water temperatures were slightly lower $\left(1-2^{\circ} \mathrm{C}\right)$ in 2008 than during the other 5 study years. For more detailed information on the environmental conditions and dam operations for individual years included in this analysis, please refer to Adams and Evans (2011).

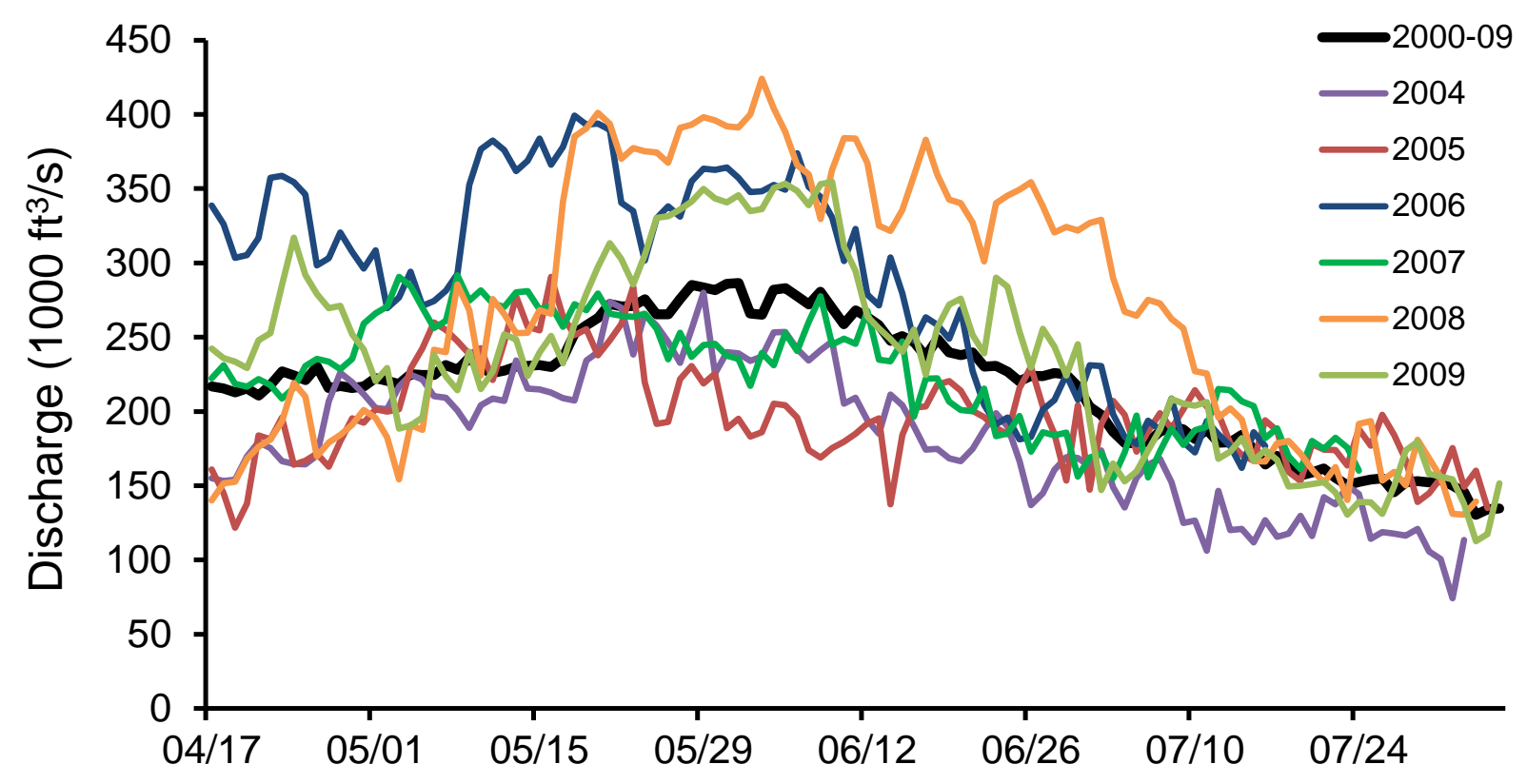

Figure 2. Hydrograph of mean daily project outflow during radio and acoustic telemetry study dates at McNary Dam, 2004-09, and the 10-year average, 2000-09. Data obtained from Columbia River DART website: http://www.cbr.washington.edu/dart/river.html. 


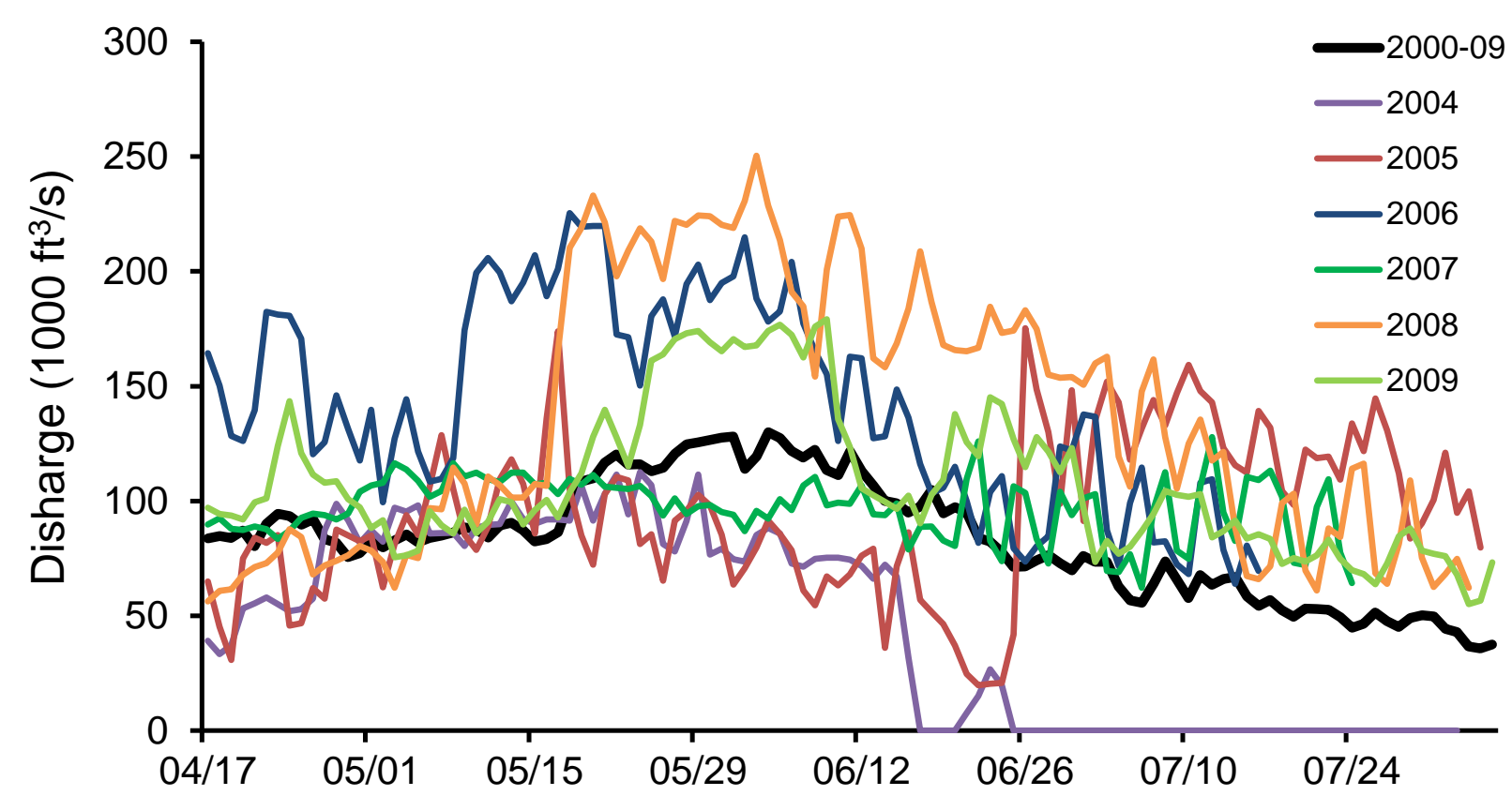

Figure 3. Hydrograph of mean daily project spill during radio and acoustic telemetry study dates at McNary Dam, 2004-09, and the ten year average, 2000-09. Data obtained from Columbia River DART website: http://www.cbr.washington.edu/dart/river.html.

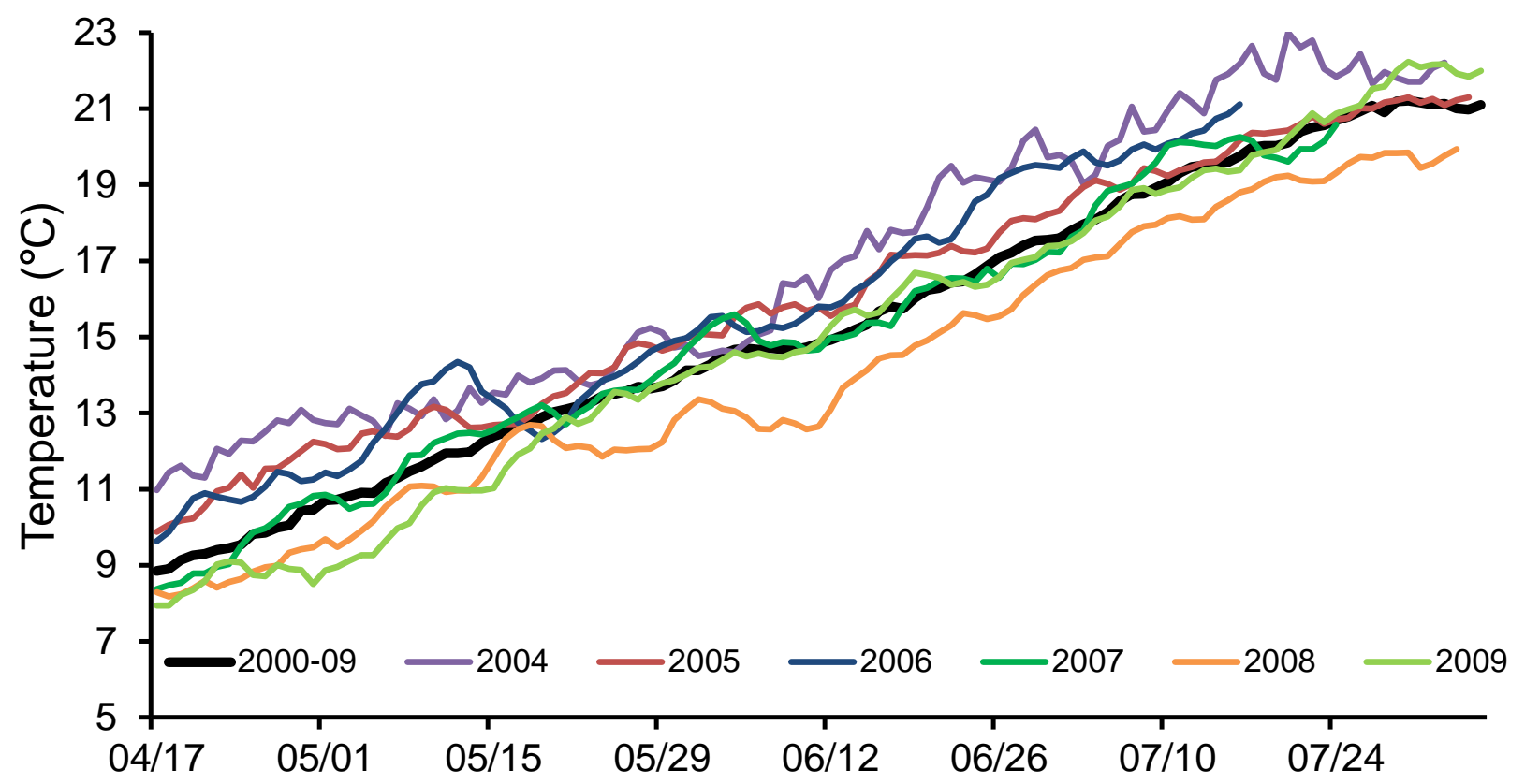

Figure 4. Hydrograph of mean daily water temperature of the Columbia River at McNary Dam during radio and acoustic telemetry study dates, 2004-09, and the 10-year average, 2000-2009. Data obtained from Columbia River DART website: $h$ ttp://www.cbr.washington.edu/dart/river.html. 


\section{Methods}

\section{Data}

We analyzed radio and acoustic telemetry data collected during the spring and summer of 200409 to examine how spill bay operations affected survival of juvenile salmonids passing through the spillway and the juvenile fish facility bypass. Telemetry equipment was deployed upstream, at, and downstream of McNary Dam to monitor fish movements. During the years included in our analyses, more than 21,000 acoustic-tagged yearling Chinook salmon (Oncorhynchus tshawytscha), juvenile steelhead (Oncorhynchus mykiss), subyearling Chinook salmon (Oncorhynchus tshawytscha), and sockeye salmon (Oncorhynchus nerka) were detected passing through the McNary Dam spillway or juvenile bypass (table 1). Yearling Chinook salmon and juvenile steelhead were hatchery-reared, although subyearling Chinook and sockeye salmon were of unknown origin. U.S. Geological Survey personnel tagged and released all yearling and subyearling Chinook salmon and juvenile steelhead used for this analysis. Treatment fish were released $10 \mathrm{~km}$ upstream of McNary Dam and control fish were released about $0.5 \mathrm{~km}$ downstream of the dam. Sockeye salmon were released in the Mid-Columbia River by personnel from Hydroacoustic Technologies Incorporated, LGL Limited, Chelan County Public Utility District, and Grant County Public Utility District. Specifications for the acoustic transmitters used in the annual studies are provided in table 2. Numbers of each species released, release dates, release sites, passage dates, and percentage of spill during dates of passage are documented in tables 3 and 4. Other details describing tags, tagging, and data-collection methods are given in Adams and others (1998, 2008), Perry and others (2006, 2007), Adams and Counihan (2009), and Adams and Liedtke (2009, 2010).Methods used to tag sockeye salmon are described by Steig and others (2007, 2008, 2009, 2010), Sullivan and others (2009), and Timko and others (2007, 2008, 2010). Survival estimates for all species were assessed from dam passage to a downstream array located from rkm 446 to 448 .

Table 1. Number of fish used in this analysis that passed through the McNary Dam spillway or bypass, 2004-09.

[NA, analysis not possible because sockeye salmon were not PIT tagged]

\begin{tabular}{lcccc}
\hline \multicolumn{1}{c}{ Route } & $\begin{array}{c}\text { Yearling } \\
\text { Chinook salmon }\end{array}$ & $\begin{array}{c}\text { Juvenile } \\
\text { steelhead }\end{array}$ & $\begin{array}{c}\text { Subyearling } \\
\text { Chinook salmon }\end{array}$ & $\begin{array}{c}\text { Sockeye } \\
\text { salmon }\end{array}$ \\
\hline Spillway & 4,405 & 3,794 & 4,213 & 2,870 \\
Bypass & 2,864 & 1,390 & 1,835 & NA \\
\hline
\end{tabular}


Table 2. Specifications of transmitters surgically implanted in juvenile salmonids, 2006-09.

[NA, not applicable]

\begin{tabular}{|c|c|c|c|c|c|c|}
\hline Year & Site & $\begin{array}{c}\text { Acoustic } \\
\text { transmitter model }\end{array}$ & $\begin{array}{l}\text { Average tag } \\
\text { dimensions } \\
\text { (millimeters) }\end{array}$ & $\begin{array}{l}\text { Average tag } \\
\text { weight in air } \\
\text { (grams) }\end{array}$ & $\begin{array}{l}\text { Average tag life } \\
\text { (days) }\end{array}$ & $\begin{array}{l}\text { PIT tag } \\
\text { model }\end{array}$ \\
\hline \multicolumn{7}{|c|}{ Yearling Chinook salmon and juvenile steelhead } \\
\hline 2006 & Columbia & $795-\mathrm{E}$ & $6.8 \times 21.0$ & 1.5 & 21 & TX1411ST \\
\hline 2007 & Columbia & 795-E & $6.8 \times 21.0$ & 1.5 & 21 & TX1411ST \\
\hline 2008 & Columbia & 795-E & $7.1 \times 21.9$ & 1.6 & 18 & TX1411ST \\
\hline 2009 & Columbia & 795-LE & $6.7 \times 21.1$ & 1.4 & 28 & TX1411ST \\
\hline \multicolumn{7}{|c|}{ Subyearling Chinook salmon } \\
\hline 2006 & Columbia & 795-M & $6.8 \times 16.5$ & 0.8 & 17 & TX1411ST \\
\hline 2007 & Columbia & 795-M & $6.8 \times 16.5$ & 0.8 & 17 & TX1411ST \\
\hline 2008 & Columbia & $795-S$ & $6.5 \times 22.2$ & 0.7 & 13 & TX1411ST \\
\hline 2009 & Columbia & 795-LM & $6.5 \times 16.3$ & 0.7 & 24 & TX1411ST \\
\hline \multicolumn{7}{|c|}{ Sockeye salmon } \\
\hline 2006 & Mid-Columbia & 795-M & $6.8 \times 16.5$ & 0.8 & 14 & NA \\
\hline 2007 & Mid-Columbia & 795-M & $6.8 \times 16.5$ & 0.8 & 14 & NA \\
\hline 2008 & Mid-Columbia & 795-M & $6.8 \times 16.5$ & 0.8 & 17 & NA \\
\hline 2009 & Mid-Columbia & 795-Lm & $5.0 \times 17.5$ & 0.7 & 22 & NA \\
\hline
\end{tabular}


Table 3. Summary statistics of fork length and weight of acoustic-tagged juvenile salmonids released in the Columbia River, by release site, 2006-09.

[Species/age class: Y. Chinook, yearling Chinook salmon; Steelhead, juvenile steelhead; S. Chinook, subyearling Chinook salmon. Release site: HAT, near Hat Rock State Park, Oregon, approximately 10 kilometers upstream of McNary Dam; TAIL, 0.5 kilometers downstream of McNary Dam in the tailrace directly out from the downstream tip of the navigation wall; SAC, intentionally sacrificed fish released at the TAIL release site; RC, Rocky Reach Collector; RR, Rocky Reach Dam; RH, Rock Island Hydro Park; RI, Rock Island Dam; WA, Wanapum Dam; WE, Wells Dam. N, number of fish; Min, minimum; Max, maximum]

\begin{tabular}{|c|c|c|c|c|c|c|c|c|c|}
\hline \multirow{2}{*}{$\begin{array}{l}\text { Speciesl } \\
\text { age class }\end{array}$} & \multirow{2}{*}{$\begin{array}{l}\text { Release } \\
\text { site }\end{array}$} & \multirow{2}{*}{$\begin{array}{c}\text { Release } \\
\text { dates }\end{array}$} & \multirow[t]{2}{*}{$\mathrm{N}$} & \multicolumn{3}{|c|}{$\begin{array}{l}\text { Fork length, } \\
\text { in millimeters }\end{array}$} & \multicolumn{3}{|c|}{ Weight, in grams } \\
\hline & & & & Mean & Min & Max & Mean & Min & Max \\
\hline \multicolumn{10}{|c|}{2006} \\
\hline Y. Chinook & HAT & $4 / 27-6 / 4$ & 1,797 & 149 & 125 & 179 & 31.7 & 23.0 & 59.5 \\
\hline Y. Chinook & TAIL & $4 / 27-6 / 4$ & 1,213 & 148 & 133 & 175 & 31.3 & 22.6 & 49.8 \\
\hline Y. Chinook & SAC & 4/30-6/1 & 49 & 148 & 134 & 174 & 31.7 & 23.0 & 48.7 \\
\hline Steelhead & HAT & 4/27-6/1 & 1,005 & 209 & 122 & 290 & 78.6 & 31.0 & 236.5 \\
\hline Steelhead & SAC & $5 / 4-5 / 31$ & 50 & 205 & 158 & 267 & 73.3 & 30.1 & 152.6 \\
\hline S. Chinook & HAT & $6 / 20-7 / 19$ & 1,794 & 120 & 104 & 155 & 17.5 & 12.5 & 44.8 \\
\hline S. Chinook & TAIL & $6 / 20-7 / 19$ & 1,191 & 120 & 108 & 158 & 17.4 & 13.5 & 44.9 \\
\hline S. Chinook & SAC & $6 / 22-7 / 11$ & 50 & 118 & 112 & 133 & 16.7 & 13.6 & 25.1 \\
\hline \multicolumn{10}{|c|}{2007} \\
\hline Y. Chinook & HAT & $4 / 19-6 / 7$ & 1,973 & 151 & 130 & 222 & 33.4 & 23.0 & 108.4 \\
\hline Y. Chinook & TAIL & 4/19-6/7 & 1,310 & 151 & 133 & 206 & 33.5 & 23.0 & 78.8 \\
\hline Y. Chinook & SAC & $4 / 27-6 / 4$ & 53 & 151 & 135 & 179 & 33.2 & 23.7 & 49.9 \\
\hline Steelhead & HAT & $4 / 21-6 / 6$ & 1,118 & 215 & 160 & 292 & 84.6 & 27.4 & 207.7 \\
\hline Steelhead & SAC & $4 / 28-6 / 2$ & 50 & 223 & 178 & 279 & 93.4 & 43.7 & 166.8 \\
\hline S. Chinook & HAT & $6 / 20-7 / 25$ & 1,771 & 118 & 105 & 166 & 17.8 & 13.2 & 55.2 \\
\hline S. Chinook & TAIL & $6 / 20-7 / 25$ & 1,182 & 118 & 105 & 168 & 17.6 & 12.8 & 59.9 \\
\hline S. Chinook & SAC & $6 / 24-7 / 24$ & 50 & 118 & 110 & 136 & 17.8 & 13.5 & 32.5 \\
\hline \multicolumn{10}{|c|}{2008} \\
\hline Y. Chinook & HAT & 4/19-6/3 & 1,424 & 154 & 131 & 206 & 36.0 & 23.0 & 147.6 \\
\hline Y. Chinook & TAIL & 4/20-6/4 & 949 & 153 & 130 & 200 & 35.5 & 23.0 & 76.7 \\
\hline Y. Chinook & SAC & 4/22-5/31 & 50 & 151 & 134 & 189 & 34.2 & 24.1 & 63.6 \\
\hline Steelhead & HAT & 4/19-6/2 & 1,186 & 211 & 136 & 289 & 82.8 & 27.5 & 224.0 \\
\hline Steelhead & TAIL & $4 / 20-6 / 3$ & 785 & 210 & 135 & 294 & 81.7 & 25.0 & 232.7 \\
\hline Steelhead & SAC & $4 / 22-5 / 31$ & 50 & 213 & 171 & 270 & 87.2 & 38.3 & 179.2 \\
\hline S. Chinook & HAT & 6/19-7/28 & 1,752 & 116 & 102 & 158 & 17.1 & 11.8 & 46.8 \\
\hline S. Chinook & TAIL & $6 / 20-7 / 29$ & 1,176 & 117 & 103 & 155 & 17.1 & 11.8 & 40.7 \\
\hline S. Chinook & SAC & $6 / 22-7 / 27$ & 50 & 117 & 107 & 142 & 17.4 & 12.4 & 33.3 \\
\hline \multicolumn{10}{|c|}{2009} \\
\hline Y. Chinook & HAT & $4 / 18-6 / 4$ & 1,411 & 164 & 134 & 240 & 44.4 & 29.0 & 119.0 \\
\hline Y. Chinook & TAIL & 4/18-6/4 & 935 & 164 & 137 & 255 & 44.7 & 29.0 & 174.0 \\
\hline Y. Chinook & SAC & $4 / 20-5 / 29$ & 51 & 161 & 143 & 195 & 41.9 & 30.4 & 75.2 \\
\hline Steelhead & HAT & 4/18-6/4 & 1,176 & 220 & 111 & 280 & 93.8 & 32.6 & 215.4 \\
\hline Steelhead & TAIL & 4/18-6/4 & 785 & 220 & 158 & 283 & 94.7 & 32.4 & 218.0 \\
\hline Steelhead & SAC & $4 / 23-5 / 29$ & 51 & 216 & 156 & 254 & 87.4 & 31.5 & 130.0 \\
\hline S. Chinook & HAT & 6/20-7/30 & 1,784 & 121 & 105 & 158 & 20.2 & 13.5 & 47.0 \\
\hline S. Chinook & TAIL & $6 / 20-7 / 30$ & 1,187 & 122 & 102 & 172 & 20.4 & 13.5 & 57.8 \\
\hline S. Chinook & SAC & $6 / 25-7 / 28$ & 51 & 118 & 109 & 148 & 18.8 & 14.0 & 38.2 \\
\hline
\end{tabular}


Table 4. Number of acoustic-tagged juvenile salmonids released in the Columbia River, number (and percentage of those released) that passed McNary Dam through any route, range of passage dates, and corresponding percentage spill of total project discharge over dates of passage at McNary Dam, by species, 2006-09.

[Species/age class: Y. Chinook, yearling Chinook salmon; Steelhead, juvenile steelhead; S. Chinook, subyearling Chinook salmon. Percentage of spill: Percentage of project discharge spilled includes the water discharged through the temporary spillway weirs]

\begin{tabular}{|c|c|c|c|c|c|}
\hline $\begin{array}{l}\text { Species/age } \\
\text { class }\end{array}$ & $\begin{array}{l}\text { Number } \\
\text { released }\end{array}$ & $\begin{array}{c}\text { Number (\%) } \\
\text { passed }\end{array}$ & $\begin{array}{c}\text { First passage } \\
\text { date }\end{array}$ & $\begin{array}{l}\text { Last passage } \\
\text { date }\end{array}$ & $\begin{array}{c}\text { Percentage of } \\
\text { spill }\end{array}$ \\
\hline \multicolumn{6}{|c|}{2006} \\
\hline Y. Chinook & 1,797 & $1,717(96)$ & $4 / 27 / 2006$ & $6 / 5 / 2006$ & 50 \\
\hline Steelhead & 1,005 & $944(94)$ & $4 / 27 / 2006$ & $6 / 2 / 2006$ & 48 \\
\hline S. Chinook & 1,791 & $1,638(91)$ & 6/20/2006 & 7/30/2006 & 49 \\
\hline Sockeye & 3,493 & 1,339 (38) & 5/10/2006 & $6 / 11 / 2006$ & 52 \\
\hline \multicolumn{6}{|c|}{2007} \\
\hline Y. Chinook & 1,974 & $1,911(97)$ & $4 / 20 / 2007$ & $6 / 9 / 2007$ & 43 \\
\hline Steelhead & 1,118 & $1,086(97)$ & $4 / 22 / 2007$ & 6/9/2007 & 41 \\
\hline S. Chinook & 1,771 & $1,631(92)$ & 6/21/2007 & 8/7/2007 & 52 \\
\hline Sockeye & 2,500 & $1,224(49)$ & 5/11/2007 & $6 / 14 / 2007$ & 41 \\
\hline \multicolumn{6}{|c|}{2008} \\
\hline Y. Chinook & 1,424 & 1,396 (98) & $4 / 19 / 2008$ & 6/8/2008 & 46 \\
\hline Steelhead & 1,186 & $1,186(100)$ & 4/19/2008 & $6 / 3 / 2008$ & 47 \\
\hline S. Chinook & 1,752 & $1,646(94)$ & 6/20/2008 & 8/8/2008 & 51 \\
\hline Sockeye & 2,002 & $1,084(54)$ & 5/18/2008 & $6 / 21 / 2008$ & 57 \\
\hline \multicolumn{6}{|c|}{2009} \\
\hline Y. Chinook & 1,403 & $1,351(96)$ & $4 / 18 / 2009$ & 6/8/2009 & 44 \\
\hline Steelhead & 1,170 & 1,107 (95) & 4/19/2009 & 6/4/2009 & 43 \\
\hline S. Chinook & 1,772 & $1,602(90)$ & 6/20/2009 & 8/7/2009 & 51 \\
\hline Sockeye & 3,974 & $3,578(90)$ & 5/18/2009 & 6/20/2009 & 50 \\
\hline
\end{tabular}




\section{Survival Analysis}

We used release-recapture models developed by Cormack (1964), Jolly (1965), and Seber (1965) (hereafter referred to as CJS) to examine how environmental variables and dam operations affect survival of juvenile salmonids passing through the spillway and juvenile fish bypass at McNary Dam. A logit link was used to relate individual and group covariates of environmental variables assigned at dam passage (table 5) to survival. Models were created and parameters estimated in the program MARK (White and Burnham, 1999).

Group covariates for photoperiod, year, passage location, spill bay type, and spill pattern were based on discrete time periods, passage structures, spillway locations, or spillway operations. For photoperiod, dark and light periods were determined using civil twilight for each day. Group covariates for passage location and spill bay type were defined based on consistencies across years so that fish were assigned as passing through a particular part of the spillway or spillway structure (table 6). Spillway passage location generally was assigned as follows: north, spill bays 1-6; middle, bays 7-15; south, bays 16-22. In 2008 it was necessary to include bay 7 in the group of north bays and bay 16 in the group of middle bays. Spill bay type was defined as either a TSW or a standard vertical lift-type spill gate depending on a fish's passage location.

Spill patterns were defined based on the percentage of total spill discharged through the north, middle, and south portions of the spillway during the spring and summer when the study fish passed the dam. The number of spill patterns and their characteristics were determined by cluster analysis using the FASTCLUS procedure in SAS ${ }^{\circledR}$ software (SAS Institute, 2008). Daily percentages of total spill discharged through each portion of the spillway were calculated for two 12-h intervals (0600-1759 and 1800-0559). Because the percentages of total spill discharged through the north and south portions of the spillway were highly correlated, only the percentage of spill for the north and middle spillway were used to create each cluster (spill pattern). The procedure was run repeatedly, allowing the total number of spill patterns defined in each sequential run to incrementally range from 2 to 10. The optimum number of patterns was determined by graphically examining the Cubic Clustering Criterion statistic for where it peaked, and the Approximate Overall R-Squared statistic for where its rate of increase began to level or taper off. Five spill patterns were used for both spring and summer for fish that passed through the spillway (fig. 5), and an additional no-spill category was added for the bypass survival analysis. Twelve-hour intervals with very little total spill discharge ( $<20 \mathrm{kcfs}$ ) were excluded from the spillway analysis and included in the no-spill category for the bypass analysis.

The individual spill bay discharge covariate for a fish's passage location was determined using the highest resolution of passage location possible given the hydrophone configuration for each year (table 6). When a specific spill bay passage assignment was not possible for a fish passing through one of the standard spill gates, we averaged individual spill bay discharges across two to seven combined spill bays. To minimize measurement error associated with this covariate, we excluded fish if the difference in spill bay discharge among the combined bays was greater than $3 \mathrm{kcfs}$. As a result, we removed 15 percent of the yearling Chinook salmon, 10 percent of the juvenile steelhead, 7 percent of the subyearling Chinook salmon, and 7 percent of the sockeye from the analysis. 
Table 5. List of variables used in survival analyses of fish passing the McNary Dam spillway and bypass, 2004-09.

\begin{tabular}{lll}
\hline Type & Name & Definition \\
\hline Group & Photoperiod & Day, night \\
Group & ${ }^{1}$ Year & yyyy, year of study \\
Group & Passage location & North, middle, or south passage location at spillway \\
Group & Bay type & Type of spill bay (conventional or TSW) \\
Group & Spill pattern & Distribution of spill (north, south, or uniform) \\
Individual & Temperature & Average daily tailrace water temperature \\
Individual & Total discharge & Total river discharge at McNary Dam \\
Individual & Spillway discharge & Discharge through the spillway (all spill bays) \\
Individual & Spill bay discharge & Discharge through individual spill bays \\
Individual & Percent spill & Percentage of discharge through the spillway \\
Individual & Fish weight & Fish weight \\
Individual & ${ }^{2}$ Tag burden & Tag weight/fish weight \\
\hline
\end{tabular}

${ }^{1}$ A secondary variable used to assess whether year could account for additional variation over and above the effect of other covariates.

${ }^{2}$ A secondary variable used in lieu of fish weight after all other variables were evaluated because of high correlation between tag burden and fish weight. 
Table 6. Yearly resolution of spill bay passage location, Temporary Spillway Weir placement (T), and lateral division.

\begin{tabular}{|c|c|c|c|c|c|c|c|c|c|c|c|c|c|c|c|c|c|c|c|c|c|c|}
\hline \multirow[b]{3}{*}{ Year } & \multicolumn{22}{|c|}{ Spill Bay Location } \\
\hline & \multicolumn{6}{|c|}{ South } & \multicolumn{9}{|c|}{ Middle } & \multicolumn{7}{|c|}{ North } \\
\hline & 22 & 21 & 20 & 19 & 18 & 17 & 16 & 15 & 14 & 13 & 12 & 11 & 10 & 9 & 8 & 7 & 6 & 5 & 4 & 3 & 2 & 1 \\
\hline 2009 & & & $T$ & & & & & & & & \multicolumn{3}{|c|}{ Spring } & & & & & & $\bar{T}$ & & & \\
\hline 2009 & & & $\mathrm{~T}$ & $\mathrm{~T}$ & & & & & & & \multicolumn{3}{|c|}{ Summer } & & & & & & & & & \\
\hline 2008 & & & $\mathrm{~T}$ & $\mathrm{~T}$ & & & & & & & & & & & & & & & & & & \\
\hline 2007 & $\mathrm{~T}$ & & $\bar{T}$ & & & & & & & & & & & & & & & & & & & \\
\hline 2006 & & & & & & & & & & & & & & & & & & & & & & \\
\hline 2005 & & & & & & & & & & & & & & & & & & & & & & \\
\hline 2004 & & & & & & & & & & & & & & & & & & & & & & \\
\hline
\end{tabular}




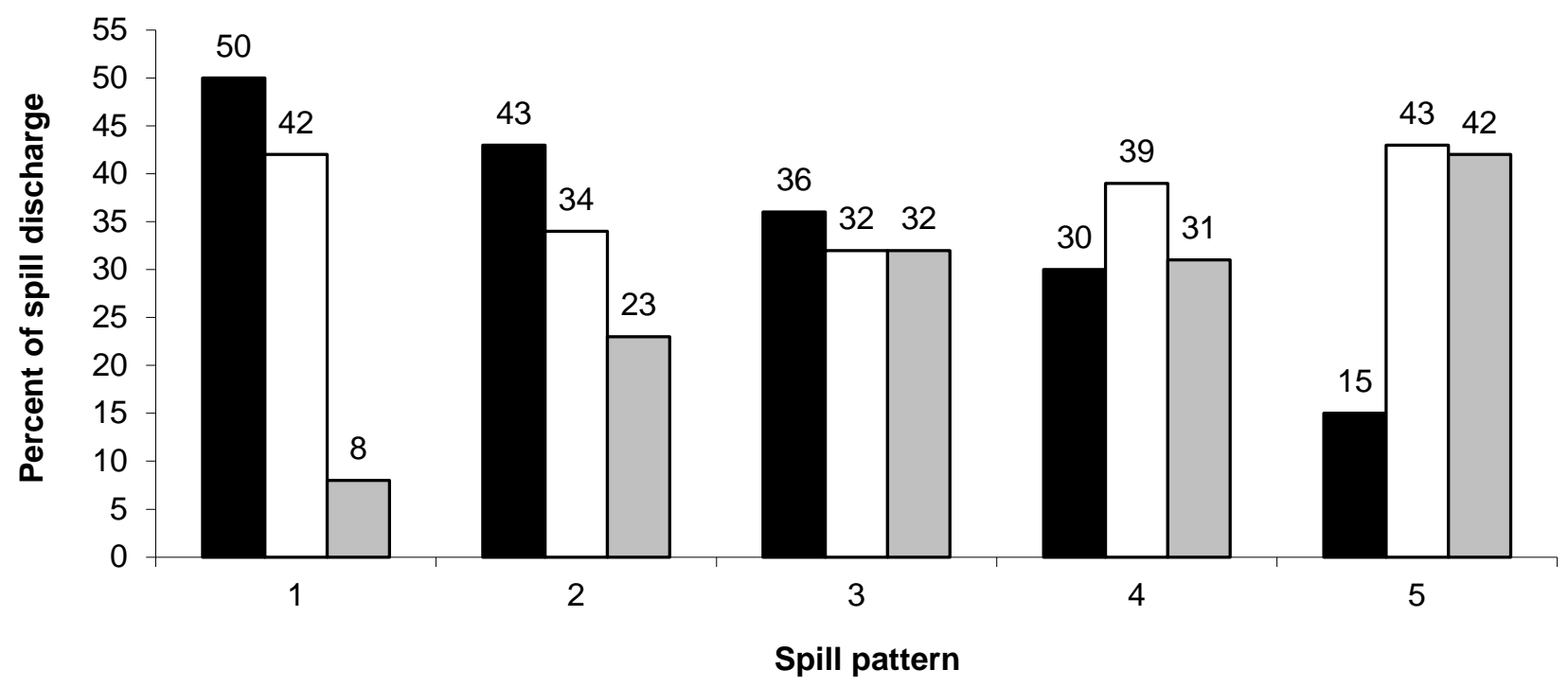

b

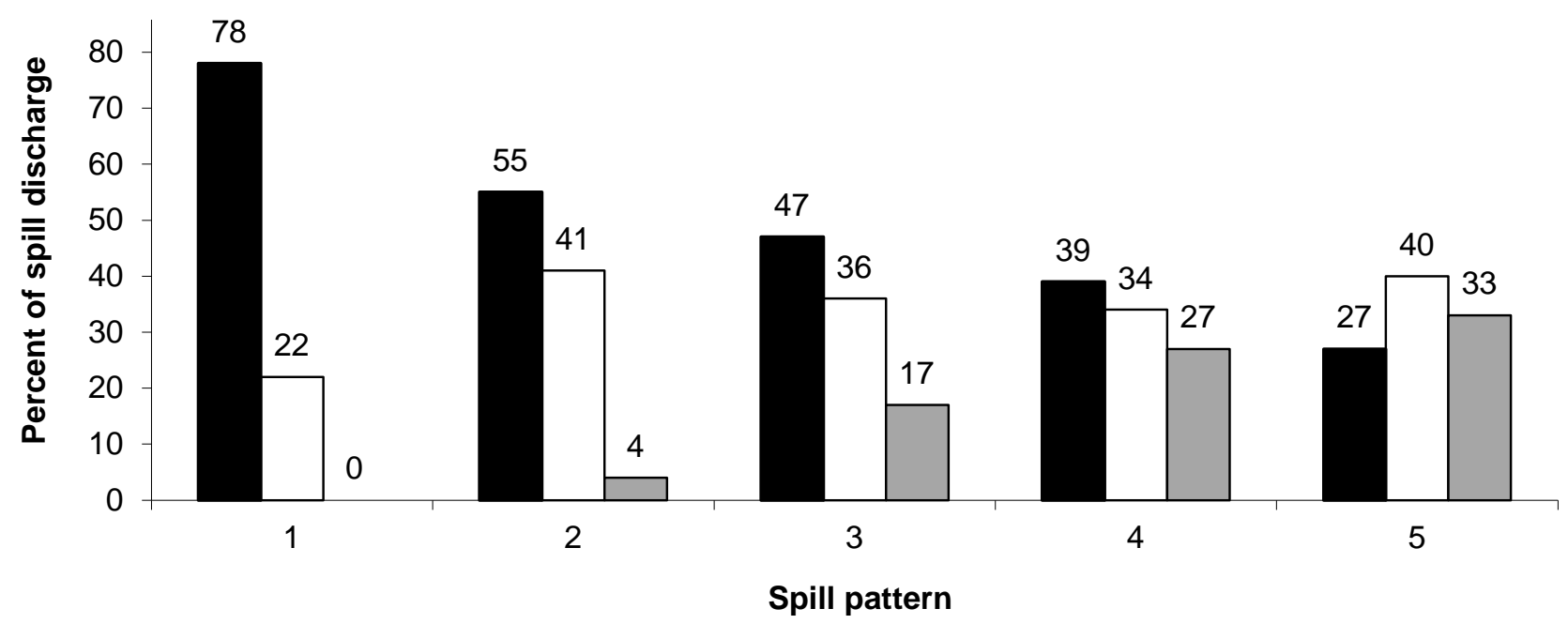

Figure 5. Percentage of spill discharge for each spill pattern during spring (a) and summer (b) study periods at McNary Dam, 2004-09. Black bars represent spill through south spill bays, white bars represent spill through middle spill bays, and gray bars represent spill through north spill bays. Numbers above bars represent percentage of spill discharge. 
An initial step in the modeling process was to assign probabilities to detection histories that represent detections of fish downstream. For example, the possible histories for survival in this study included: $111,101,110$, and 100 , where a 1 represents detection at a telemetry array and a 0 represents nondetection. The first digit represents a fish that was released or that passed through a particular passage route, the second digit represents the first downstream detection array, and the last digit represents detection at the last detection array. The probabilities of these capture histories were then incorporated into a multinomial probability model to estimate model parameters using maximum likelihood methods. The model parameters included: $\varnothing$, the probability of survival from dam passage through the spillway or bypass to the first downstream detection array; $p$, the probability of being detected at the first downstream detection array given the individual survived; and $\lambda$, the joint probability of surviving and being detected from the first downstream array to the next downstream array (fig. 6). The probabilities of the possible detection histories can be expressed as:

$P_{111}: \varnothing p \lambda$

$P_{101}: \varnothing(1-p) \lambda$

$P_{110}: \varnothing p(1-\lambda)$

$P_{100}:(1-\varnothing)+\varnothing(1-p)(1-\lambda),(1)$

To express survival as a function of covariates, we used a logit link function, which models the logit of each parameter as a linear function of covariates. For example, a model of survival as a function of photoperiod and a continuous covariate, $\mathrm{x}$, can be expressed as:

$\varnothing($ photo $+x i)=\exp \left(\beta_{0}+\beta_{\text {photo }}+\beta_{1} x i\right) / 1+\exp \left(\beta_{0}+\beta_{\text {photo }}+\beta_{1} x i\right),(2)$

In this expression, $\beta$ represents the intercept and slope coefficients. The logit link also was used for estimating our detection parameters. The logit link was used to estimate all model parameters because it constrains parameter estimates between 0 and 1 , which is appropriate for probabilities. A quadratic term was included in models where there was potential for a unimodal curvilinear response of fish survival to a particular covariate. We found that adding this term to models never resulted in a significant effect, so we did not present the results.

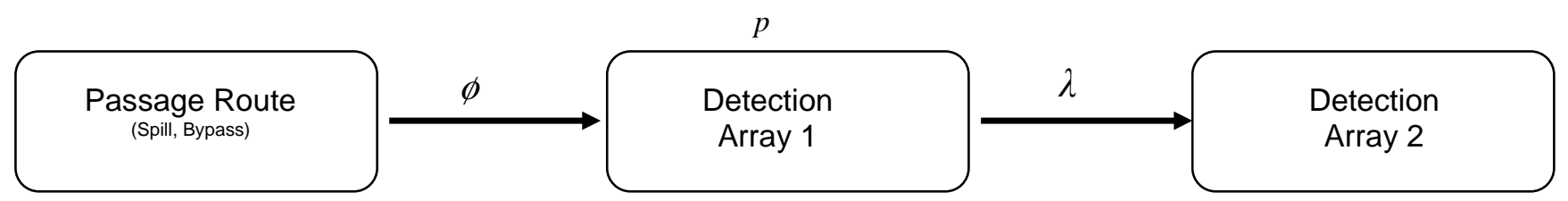

Figure 6. Schematic of the mark-recapture model used to estimate survival ( $\varnothing$ ) and detection probabilities $(p)$ of juvenile salmonids passing through McNary Dam for releases during 2004-09. 
To assess how well the covariates or environmental variables explained model parameters, Akaike's Information Criterion (AIC) (Akaike, 1973; Burnham and Anderson, 1998) was used for comparing models. AIC allowed us to measure how well the model fit relative to the number of parameters used in the model:

$$
A I C=-2 L+2 N,(3)
$$

where $N$ is the number of parameters and $L$ is the log-likelihood. Although our sample sizes were large, we used $\mathrm{AIC}_{c}$

$$
A I C_{C}=-2 L+2 N+(2 N(N+1) /(n-N-1)),(4)
$$

which is a modification for small sample sizes in relation to the number of parameters in a model where $n$ is sample size. When sample sizes are large in relation to the number of parameters in a model, $\mathrm{AIC}_{c}$ is equivalent to $\mathrm{AIC}$, thus $\mathrm{AIC}_{c}$ provides more flexibility when sample size varies over a large range. Further, $\mathrm{AIC}_{c}$ can be used to compare nested and non-nested models, as opposed to strictly using a Likelihood Ratio Test, which is restricted to nested models.

We interpreted $\triangle \mathrm{AIC}_{c}$ values based on the recommendations of Burnham and Anderson (1998), where $\Delta \mathrm{AIC}_{c}<2$ between two models suggests no evidence that one of the models is best; $2<\Delta \mathrm{AIC} c$ 10 suggests some evidence; and $\Delta \mathrm{AIC}_{c}>10$ suggests strong evidence that the model with the smaller $\mathrm{AIC}_{c}$ is the best model. Many of our model runs resulted in nested models having a $\triangle \mathrm{AIC}_{\mathrm{c}}<2$. In these cases, candidate models were determined by examining the deviance or likelihood. If nested models differed by only one parameter and the deviance was nearly equal between models, then this suggested the additional parameter did not improve model fit. Therefore, we eliminated the model with the additional parameter from the candidate set. Model selection tables shown in the results of this report contain only models with $\Delta \mathrm{AIC}_{\mathrm{c}}<10$; however, appendixes $\mathrm{A}$ and $\mathrm{B}$ contain all candidate models for survival of fish passing through the spillway and bypass outfall, respectively, regardless of $\Delta \mathrm{AIC} \mathrm{C}_{\mathrm{c}}$ value.

We took a hierarchical approach to model selection by evaluating detection parameters and determining the best model using $\mathrm{AIC}_{\mathrm{c}}$ similar to the strategy of Lebreton and others (1992). The best model for detection probabilities was used for all other analyses when examining survival. We began our model selection at the farthest downstream parameter, $\lambda$, and worked our way upriver (starting with $\lambda$ and then $p$ ). We tested and incorporated the possibility that $\lambda$ could be related to fish weight or tag burden into the detection probability model where the model fit was improved and then assessed survival of juvenile salmonids as a function of covariates. Various combinations of variables were created for each model to represent potential drivers, or previous hypotheses, as to which factors influence survival of juvenile salmonids as they migrate past McNary Dam. Although hypotheses were developed previously, selection procedures were used conceptually so that important hypotheses were not left out of the model set, which could occur without a systematic approach to hypotheses development (Collett, 2003). The effect of "study year" was then added to the best models to assess additional variation not explained by covariates. Variables that were highly correlated (for example, fish weight and tag burden, total discharge and spill discharge) were substituted into the best models with their correlate to assess which variable was more important or had more influence regarding model fit, but were not kept within the same model if they were highly correlated. 
There are assumptions that are made when using mark-recapture models. For CJS models, these assumptions relate to inferences to the population of interest, error in interpreting acoustic signals, and statistical fit of the data to the structure of the model. The assumptions are:

1. Tagged individuals are representative of the population of interest.

2. Survival probabilities of tagged fish are the same as those of untagged fish. For example, the tagging procedures or detection of fish at downstream telemetry arrays should not influence survival or detection probabilities. If the tag negatively affected survival, then estimates of survival rates will be biased accordingly. In this study, tag burden was examined as a covariate.

3. All sampling events are instantaneous. That is, sampling should take place over a short distance relative to the distance between telemetry arrays so that the chance of mortality at a telemetry array is minimized. This assumption is necessary to attribute mortality correctly to a specific river reach. This assumption usually is satisfied by the location of telemetry arrays.

4. The fate of each tagged fish is independent of the fate of other tagged fish. Therefore, survival or mortality of one fish has no effect on the survival or mortality of the other fish.

5. The prior detection history of a tagged fish has no effect on its subsequent survival. This assumption could be violated if parts of the river are not monitored for tagged fish. For acoustic telemetry, this assumption usually is satisfied by the passive nature of detecting acoustic tags, by monitoring all routes of passage at a dam, and by monitoring the entire cross section of the river channel.

6. All tagged fish alive at a sampling location have the same detection probability. This assumption also could be violated as described in assumption 5, but usually is satisfied with acoustic telemetry by monitoring the entire cross section of the river channel.

7. All tags are identified correctly and the status of tagged fish (that is, alive or dead) is known without error. This assumes that fish do not lose their tags and that the tag is functioning when the fish is in the study area. Additionally, the assumption is that all detections are of live fish and that dead fish are not detected and interpreted as live (that is, false-positive detections). This assumption is addressed by releasing tagged, dead fish and seeing if the fish are detected at the detection arrays used to assess survival of juvenile salmonids. Tag life studies are performed in conjunction with field studies.

There are formal ways proposed by Burnham and others (1987) to test some of these assumptions, such as the independence of fate of individuals, fish in a group having equal survival and detection probabilities, and prior recapture history not influencing survival and detection probabilities downstream. However, these tests require three downstream detection sites that we did not have during all study years. Nonetheless, others have found that survival estimates generated using CJS models are robust to many violations of these assumptions (Skalski and others, 1998). Tag life studies and the release of tagged, dead fish were conducted during field studies (Adams and others, 1998, 2008; Adams and Counihan, 2009; Adams and Liedtke, 2009, 2010; Perry and others, 2006, 2007; Timko and others, 2007, 2008, 2010; Steig and others, 2007, 2008, 2009, 2010; and Sullivan and others, 2009). 


\section{Results}

\section{Yearling Chinook Salmon}

\section{Survival Analysis}

The best supported spillway and bypass models for $p$ and $\lambda$ for yearling Chinook salmon included a year effect for both parameters (table 7). These models of $p$ and $\lambda$ were used for all other spillway and bypass survival analyses.

Table 7. Model selection results based on varying $\lambda$ and $p$ with respect to year for yearling Chinook salmon, 200409.

[The best-fit models are indicated in bold. The Phi $(\varnothing)$ portion of the model was held constant for all models of $\lambda$ and $p$. The best-fit model for $\lambda$ was determined first and then used to assess the best-fit model for $p$. $\varnothing$, the probability of survival from dam passage through a route to the first downstream detection array; $p$, the probability of being detected at the first downstream detection array given the individual survived; $\lambda$, the joint probability of surviving and being detected from the first downstream array to the next downstream array; g, all combinations of the photoperiod, passage location, bay type, spill pattern, and year group covariates; $\mathrm{y}$, year; $\mathrm{AIC}_{c}$, Akaike’s Information Criterion]

\begin{tabular}{|c|c|c|c|c|c|}
\hline No. & Model & $\begin{array}{l}\text { Number of } \\
\text { parameters }\end{array}$ & $\mathrm{AIC}_{c}$ & $\Delta \mathrm{AlC}_{c}$ & Deviance \\
\hline \multicolumn{6}{|c|}{ Spillway } \\
\hline 1 & $\varnothing(\mathrm{g}) p(\mathrm{y}) \lambda(\mathrm{y})$ & 117 & $8,312.50$ & 0.00 & $8,074.82$ \\
\hline 2 & $\varnothing(\mathrm{g}) p(\mathrm{y}) \lambda$ & 112 & 8,709.94 & 397.45 & $8,482.58$ \\
\hline 3 & $\varnothing(\mathrm{g}) p \lambda(\mathrm{y})$ & 112 & $9,047.15$ & 734.65 & $8,819.78$ \\
\hline \multicolumn{6}{|c|}{ Bypass } \\
\hline 1 & $\varnothing(\mathrm{g}) p(\mathrm{y}) \lambda(\mathrm{y})$ & 48 & $5,593.62$ & 0.00 & $5,496.64$ \\
\hline 2 & $\varnothing(\mathrm{g}) p(\mathrm{y}) \lambda$ & 43 & $5,727.26$ & 133.64 & $5,640.47$ \\
\hline 3 & $\varnothing(\mathrm{g}) p \lambda(\mathrm{y})$ & 43 & $6,168.51$ & 574.88 & $6,081.71$ \\
\hline
\end{tabular}


Spillway survival of yearling Chinook salmon was best explained by the model that included tag burden, spill bay discharge, bay type, temperature, and the interaction between spill bay discharge and bay type (table 8). Tag burden and bay type were both negatively related to spillway survival, and the remaining covariates were positively related to spillway survival (table 9). The model that included tag burden, spill bay discharge, bay type, and temperature (but not the interaction between spill bay discharge and bay type) also was well supported with an $\mathrm{AIC}_{\mathrm{c}}$ within 1.38 of the model that included the interaction, indicating no difference between the two models (table 8). Fifteen other models, all of which included tag burden, had $\mathrm{AIC}_{\mathrm{c}}$ values within 10 units of the best model and, therefore, provide some explanation of spillway survival for yearling Chinook salmon (table 8). We found that spillway survival increased as spill bay discharge increased for both bay types, and that survival was higher for fish passing through conventional spill bays compared to TSW bays (fig. 7). Similarly, spillway survival increased as total discharge increased for all spill patterns. Survival was highest (94 percent or higher) for spill patterns that discharged the most spill through the north or south portions of the spillway (patterns 1 and 5), and least for spill patterns that discharged water more uniformly through all portions of the spillway (fig. 8).

The best-fit model for survival of fish passing through the juvenile bypass outfall included only the group covariate for photoperiod and was only slightly better $\left(1.12 \Delta \mathrm{AIC}_{c}\right)$ than the intercept model (table 10). Bypass survival was lower during the day than at night (table 9). The only covariate associated with spill operations that we modeled that provided any support to bypass survival was spill pattern (table 10). The model that included photoperiod and spill pattern had an $\mathrm{AIC}_{\mathrm{c}}$ value 5.51 units lower than the model with photoperiod alone, and the model that included only spill pattern had an $\mathrm{AIC}_{\mathrm{c}}$ value 6.21 units lower than the best model. Based on these $\mathrm{AIC}_{\mathrm{c}}$ values, spill pattern provided little explanation of variation in bypass survival for yearling Chinook salmon. 
Table 8. Model selection for fish that passed through the spillway at McNary Dam relating survival ( $\varnothing$ ) as a function of individual and group covariates using the fixed structure of the best model for $p$ and $\lambda$ parameters for yearling Chinook salmon, 2004-09.

[The best-fit models are indicated in bold. Q, discharge]

\begin{tabular}{lcccc}
\hline \multicolumn{1}{c}{ Model } & $\begin{array}{c}\text { Number of } \\
\text { parameters }\end{array}$ & AlC $_{\boldsymbol{c}}$ & AAIC $_{c}$ & Deviance \\
\hline Tag burden + Spill bay Q + Bay type + Temperature + Spill bay Q*Bay type & $\mathbf{1 8}$ & $\mathbf{8 , 1 9 9 . 6 2}$ & $\mathbf{0 . 0 0}$ & $\mathbf{8 , 1 6 3 . 5 3}$ \\
Tag burden + Spill bay Q + Bay type + Temperature & $\mathbf{1 7}$ & $\mathbf{8 , 2 0 1 . 0 0}$ & $\mathbf{1 . 3 8}$ & $\mathbf{8 , 1 6 6 . 9 2}$ \\
Tag burden + Spill bay Q + Bay type & 16 & $8,201.81$ & 2.18 & $8,169.73$ \\
Tag burden + Total Q + Temperature & 16 & $8,202.53$ & 2.90 & $8,170.46$ \\
Tag burden + Spill bay Q + Temperature & 16 & $8,202.70$ & 3.08 & $8,170.63$ \\
Tag burden + Total Q + Temperature + Passage location & 18 & $8,203.22$ & 3.60 & $8,167.13$ \\
Tag burden + Temperature & 15 & $8,203.45$ & 3.82 & $8,173.38$ \\
Tag burden + Total Q & 15 & $8,203.86$ & 4.24 & $8,173.80$ \\
Tag burden + Total Q + Passage location & 17 & $8,203.99$ & 4.37 & $8,169.91$ \\
Tag burden + Temperature + Passage location & 17 & $8,204.42$ & 4.80 & $8,170.34$ \\
Tag burden + Total Q + Spill pattern & 19 & $8,205.03$ & 5.40 & $8,166.93$ \\
Tag burden + Spill Q & 15 & $8,206.33$ & 6.71 & $8,176.27$ \\
Tag burden + Spill Q + Passage location & 17 & $8,206.71$ & 7.09 & $8,172.63$ \\
Tag burden + Spill pattern + Temperature & 19 & $8,207.03$ & 7.41 & $8,168.93$ \\
Tag burden + Spill pattern & 18 & $8,207.95$ & 8.32 & $8,171.86$ \\
Tag burden + Spill bay Q & 15 & $8,208.43$ & 8.81 & $8,178.37$ \\
Tag burden + Spill bay Q + Passage location & 17 & $8,209.43$ & 9.81 & $8,175.35$ \\
\hline
\end{tabular}


Table 9. Slope (Beta) coefficients, standard error, and 95-percent confidence limits of model parameters for yearling Chinook salmon passing McNary Dam, 2004-09.

[CL, confidence limit]

\begin{tabular}{|c|c|c|c|c|}
\hline Variable & Beta & $\begin{array}{l}\text { Standard } \\
\text { error }\end{array}$ & Lower CL & Upper CL \\
\hline \multicolumn{5}{|c|}{ Spillway } \\
\hline Intercept & 2.338 & 0.677 & 1.011 & 3.666 \\
\hline Tag burden & -0.324 & 0.084 & -0.488 & -0.161 \\
\hline Spill bay discharge & 0.114 & 0.049 & 0.019 & 0.210 \\
\hline Bay type & -0.992 & 0.305 & -1.590 & -0.394 \\
\hline Temperature & 0.111 & 0.059 & -0.004 & 0.227 \\
\hline Bay type*spill bay discharge & 0.074 & 0.038 & -0.001 & 0.149 \\
\hline \multicolumn{5}{|c|}{ Bypass } \\
\hline Intercept & 3.009 & 0.227 & 2.563 & 3.455 \\
\hline Photoperiod (light) & -0.413 & 0.247 & -0.898 & 0.072 \\
\hline
\end{tabular}




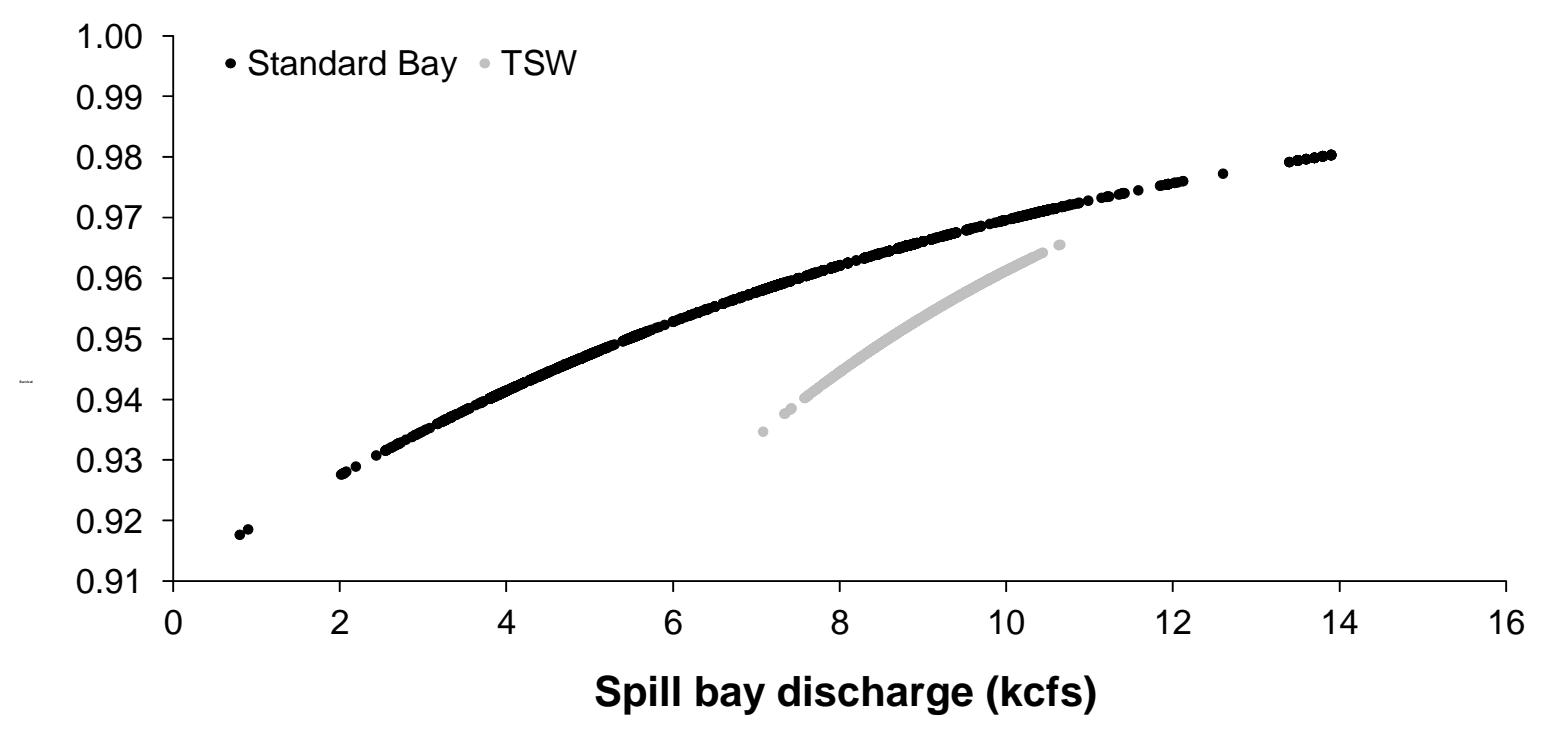

Figure 7. Survival of yearling Chinook salmon that passed through conventional spill bays (black plot) and the TSWs (gray plot) at McNary Dam in relation to spill bay discharge, 2004-09. Other covariates in the model were held constant at their mean value to examine the relationship to the variable of interest. 


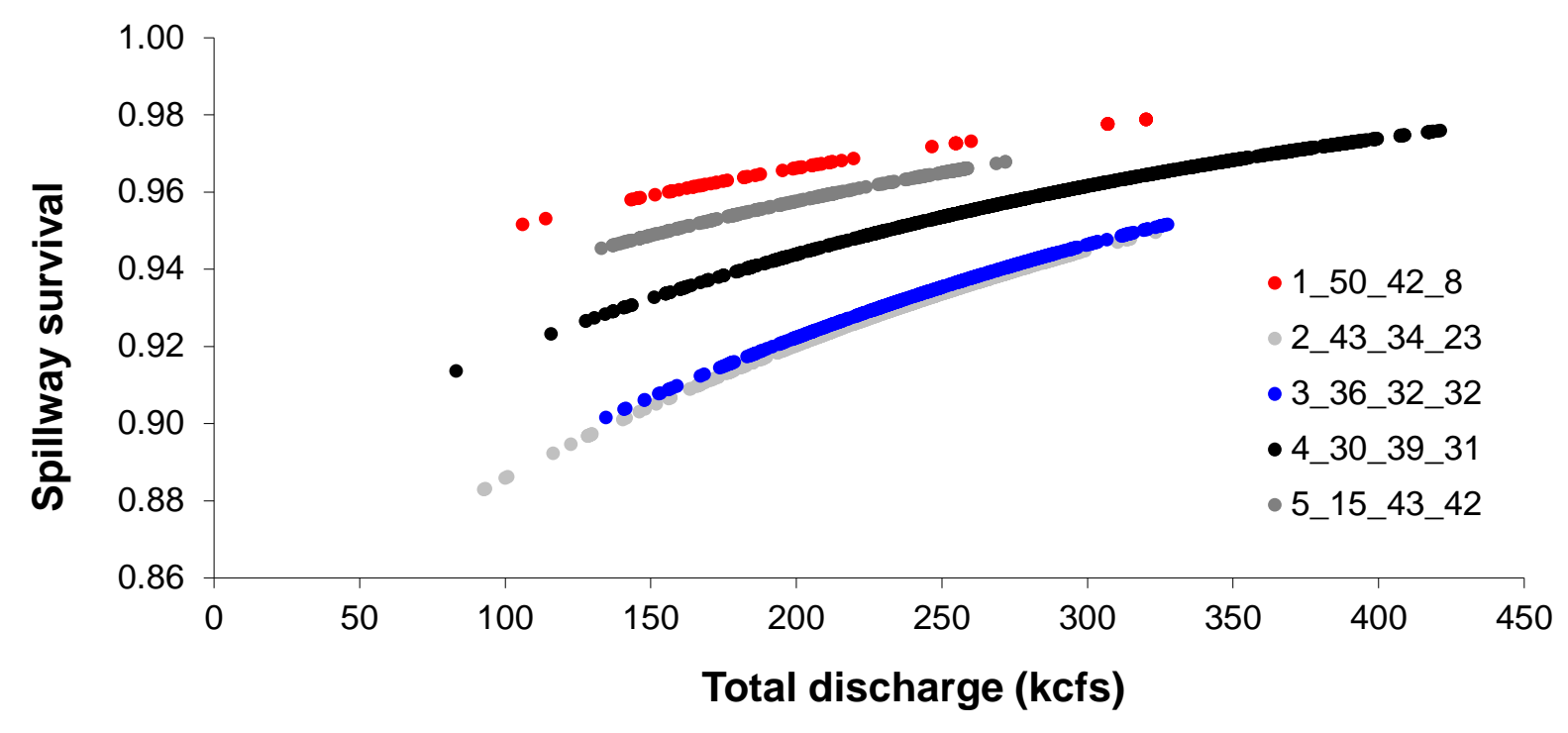

Figure 8. Spillway survival of yearling Chinook salmon in relation to total discharge for each spill pattern at McNary Dam, 2004-09. Other covariates in the model were held constant at their mean value to examine the relationship to the variable of interest. Legend text identifies the spill pattern number followed by the associated percentage of spill discharge through the south, middle, and north portions of the spillway, respectively. 
Table 10. Model selection for fish that passed through the juvenile bypass system outfall at McNary Dam relating survival (ø) as a function of individual and group covariates using the fixed structure of the best model for $p$ and $\lambda$ parameters for yearling Chinook salmon, 2004-09.

[The best-fit models are indicated in bold]

\begin{tabular}{lcccc}
\hline \multicolumn{1}{c}{ Model } & $\begin{array}{c}\text { Number of } \\
\text { parameters }\end{array}$ & AIC $_{c}$ & $\Delta$ AIC $_{c}$ & Deviance \\
\hline Photoperiod & $\mathbf{1 4}$ & $\mathbf{5 , 5 5 3 . 4 8}$ & $\mathbf{0 . 0 0}$ & $\mathbf{5 , 5 2 5 . 3 9}$ \\
Intercept & $\mathbf{1 3}$ & $\mathbf{5 , 5 5 4 . 6 0}$ & $\mathbf{1 . 1 2}$ & $\mathbf{5 , 5 2 8 . 5 2}$ \\
Photoperiod + Spill pattern & 19 & $5,558.99$ & 5.51 & $5,520.84$ \\
Spill pattern & 18 & $5,559.69$ & 6.21 & $5,523.55$ \\
\hline
\end{tabular}

\section{Juvenile Steelhead}

\section{Survival Analysis}

The best supported models for $p$ and $\lambda$ for juvenile steelhead included a year effect for both parameters. The fit of the $\lambda$ models was further improved by the addition of the tag burden covariate for fish that passed through the spillway and the fish weight covariate for fish that passed through the juvenile bypass system (table 11).

The best-fit model for fish passing through the spillway included temperature, spillway discharge, and fish weight (table 12). Survival was negatively related to temperature, but positively related to spillway discharge and fish weight (table 13, fig. 9). The model that replaced spillway discharge with total discharge and spill pattern also was well supported (1.81 $\Delta \mathrm{AIC}_{c}$, table 12). Spillway survival increased as total discharge increased for all spill patterns, and spill patterns one and four provided the highest spillway survival (fig. 10). Four other models, all of which included temperature and fish weight, and three that included at least one covariate related to spillway operations, were within 4.5 $\mathrm{AIC}_{c}$ units, and therefore provided some support to variation in spillway survival. The addition of a year factor to five of the top six models improved the models substantially, decreasing $\Delta \mathrm{AIC}_{c}$ by 5.45 , 6.88, 7.62, 5.64, and 4.40, respectively (table 12).

The model that best explained survival of juvenile steelhead passing McNary Dam through the juvenile bypass system outfall included temperature and total discharge (table 14). Bypass survival was negatively related to increasing water temperature, but positively related to increasing total discharge (table 13). The second best model included temperature and spill discharge and was within 1.21 $\mathrm{AIC}_{\mathrm{c}}$ of the best model (table 14). 
Table 11. Model selection results based on varying $\lambda$ and $p$ with respect to year for juvenile steelhead at McNary Dam, 2004-09.

[The best-fit models are indicated in bold. The Phi $(\varnothing)$ portion of the model was held constant for all models of $\lambda$ and $p$. The best-fit model for $\lambda$ was determined first and then used to assess the best-fit model for $p$. $\varnothing$, the probability of survival from dam passage through a route to the first downstream detection array; $p$, the probability of being detected at the first downstream detection array given the individual survived; $\lambda$, the joint probability of surviving and being detected from the first downstream array to the next downstream array; g, all combinations of the photoperiod, passage location, bay type, spill pattern, and year group covariates; y, year]

\begin{tabular}{|c|c|c|c|c|}
\hline Model & $\begin{array}{l}\text { Number of } \\
\text { parameters }\end{array}$ & $\mathrm{AIC}_{c}$ & $\Delta \mathrm{AlC}_{c}$ & Deviance \\
\hline \multicolumn{5}{|c|}{ Spillway } \\
\hline $1 \quad \sigma\left(\mathrm{g}^{*} \mathrm{t}\right) p(\mathrm{y}) \lambda(\mathrm{y}+$ tag burden $)$ & 114 & $6,579.59$ & 0.00 & $6,347.36$ \\
\hline $2 \quad \varnothing\left(\mathbf{g}^{*} \mathbf{t}\right) p(\mathrm{y}) \lambda(\mathrm{y})$ & 113 & $6,605.77$ & 26.18 & $6,375.61$ \\
\hline $3 \varnothing\left(\mathbf{g}^{*} \mathbf{t}\right) p(\mathrm{y}) \lambda$ & 108 & $6,659.25$ & 79.66 & $6,439.46$ \\
\hline $4 \quad \varnothing\left(\mathbf{g}^{*} \mathbf{t}\right) p \lambda(\mathrm{y})$ & 108 & $7,486.42$ & 906.83 & $7,266.63$ \\
\hline \multicolumn{5}{|c|}{ Bypass } \\
\hline $1 \quad \sigma(\mathrm{g}) p(\mathrm{y}) \lambda(\mathrm{y}+$ fish weight $)$ & 49 & $2,609.71$ & 0.00 & $2,509.61$ \\
\hline $3 \varnothing(\mathbf{g}) p(\mathrm{y}) \lambda$ & 42 & $2,663.70$ & 53.99 & $2,578.16$ \\
\hline $2 \quad \varnothing(\mathbf{g}) p(\mathrm{y}) \lambda(\mathrm{y})$ & 47 & $2,694.79$ & 85.08 & $2,512.35$ \\
\hline $4 \quad \varnothing(\mathbf{g}) p \lambda(\mathrm{y})$ & 42 & $2,865.14$ & 255.43 & $2,779.60$ \\
\hline
\end{tabular}


Table 12. Model selection for fish that passed through the spillway at McNary Dam relating survival (ø) as a function of individual and group covariates using the fixed structure of the best model for $p$ and $\lambda$ parameters for juvenile steelhead, 2004-09.

[The best-fit models are indicated in bold]

\begin{tabular}{|c|c|c|c|c|}
\hline Model & $\begin{array}{l}\text { Number of } \\
\text { parameters }\end{array}$ & $\mathrm{AIC} c$ & $\Delta \mathrm{AIC} c$ & Deviance \\
\hline Temperature + Spill discharge + Fish weight ${ }^{1}$ & 17 & 6,464.37 & 0.00 & $6,430.27$ \\
\hline Temperature + Total discharge + Spill pattern + Fish weight $^{2}$ & 21 & $6,466.18$ & 1.81 & $6,424.04$ \\
\hline Temperature + Total discharge + Percent spill + Fish weight $^{3}$ & 18 & $6,466.72$ & 2.35 & $6,430.61$ \\
\hline Temperature + Total discharge + Spill pattern + Total discharge*Spill pattern + Fish weight ${ }^{4}$ & 25 & $6,467.26$ & 2.89 & $6,417.05$ \\
\hline Temperature + Spill discharge + Spill pattern + Fish weight & 21 & $6,468.25$ & 3.88 & $6,426.10$ \\
\hline Temperature + Total discharge + Fish weight ${ }^{5}$ & 17 & $6,468.82$ & 4.45 & $6,434.73$ \\
\hline Temperature + Spill bay discharge + Spill pattern + Fish weight & 21 & $6,471.93$ & 7.56 & $6,429.79$ \\
\hline Temperature + Spill pattern + Fish weight & 20 & $6,473.18$ & 8.81 & $6,433.05$ \\
\hline Temperature + Spill discharge & 16 & $6,473.82$ & 9.45 & $6,441.73$ \\
\hline
\end{tabular}

${ }^{1}$ Addition of year to this model decreased $\mathrm{AIC}_{\mathrm{c}}$ by 5.45 .

${ }^{2}$ Addition of year to this model decreased $\mathrm{AIC}_{\mathrm{c}}$ by 6.88 .

${ }^{3}$ Addition of year to this model decreased AIC $_{\mathrm{c}}$ by 7.62 .

${ }^{4}$ Addition of year to this model decreased AIC $_{c}$ by 5.64 .

${ }^{5}$ Addition of year to this model decreased $\mathrm{AIC}_{\mathrm{c}}$ by 4.40 . 
Table 13. Slope (Beta) coefficients, standard error, and 95-percent confidence limits of model parameters for juvenile steelhead passing McNary Dam, 2004-09.

[CL, confidence limit. The addition of year improved model fit for spillway survival]

\begin{tabular}{|c|c|c|c|c|}
\hline Variable & Beta & $\begin{array}{l}\text { Standard } \\
\text { error }\end{array}$ & Lower CL & Upper CL \\
\hline \multicolumn{5}{|c|}{ Spillway } \\
\hline Intercept & 4.605 & 0.651 & 3.329 & 5.881 \\
\hline Temperature & -0.313 & 0.053 & -0.417 & -0.209 \\
\hline Fish weight & 0.010 & 0.003 & 0.004 & 0.016 \\
\hline Spill discharge & 0.009 & 0.002 & 0.004 & 0.013 \\
\hline \multicolumn{5}{|c|}{ Bypass } \\
\hline Intercept & 4.877 & 1.113 & 2.696 & 7.059 \\
\hline Temperature & -0.292 & 0.092 & -0.472 & -0.112 \\
\hline Total discharge & 0.006 & 0.002 & 0.002 & 0.010 \\
\hline
\end{tabular}




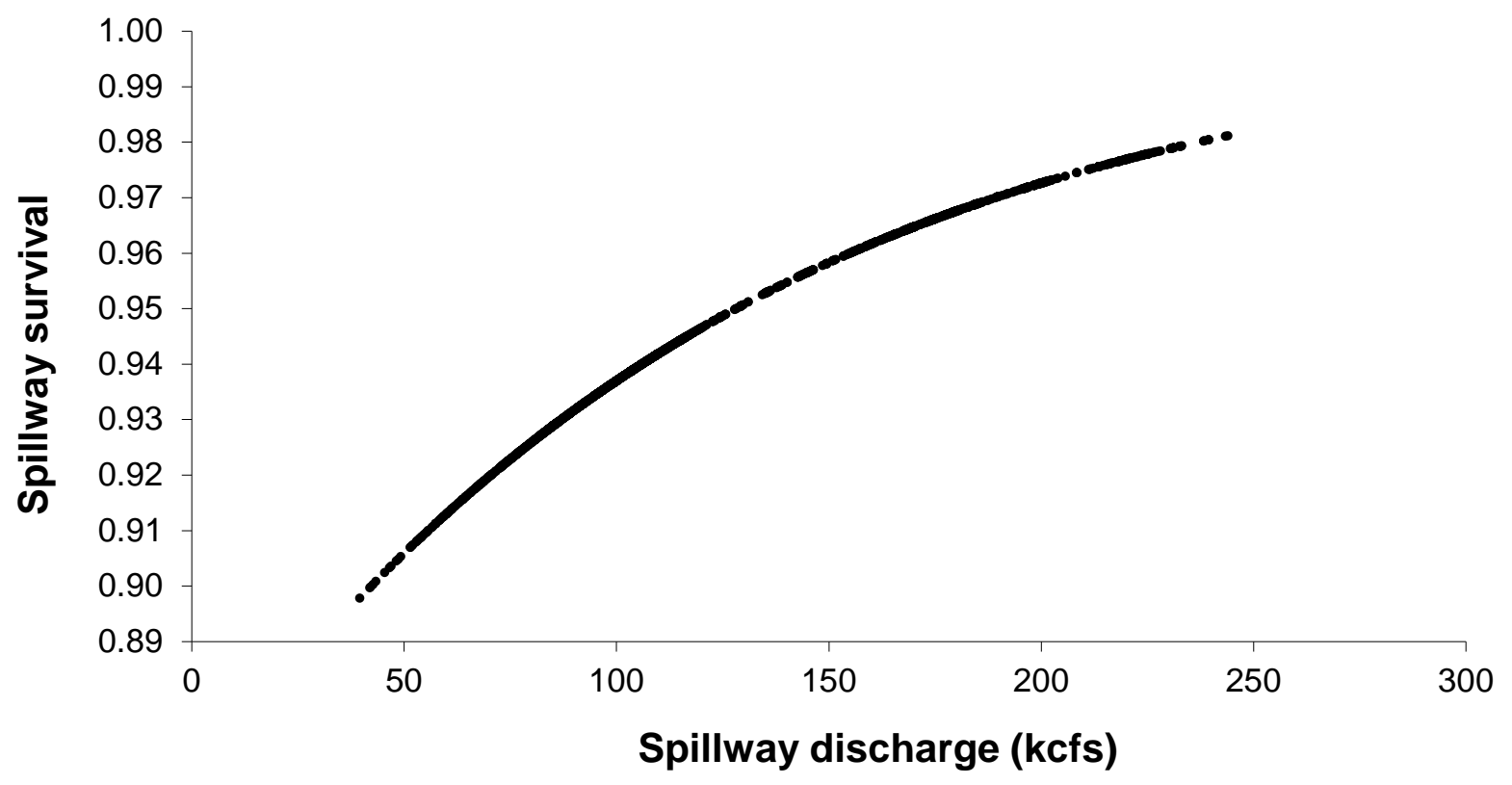

Figure 9. Spillway survival of juvenile steelhead in relation to spillway discharge at McNary Dam, 2004-09. Other covariates in the model were held constant at their mean value to examine the relationship to the variable of interest. 


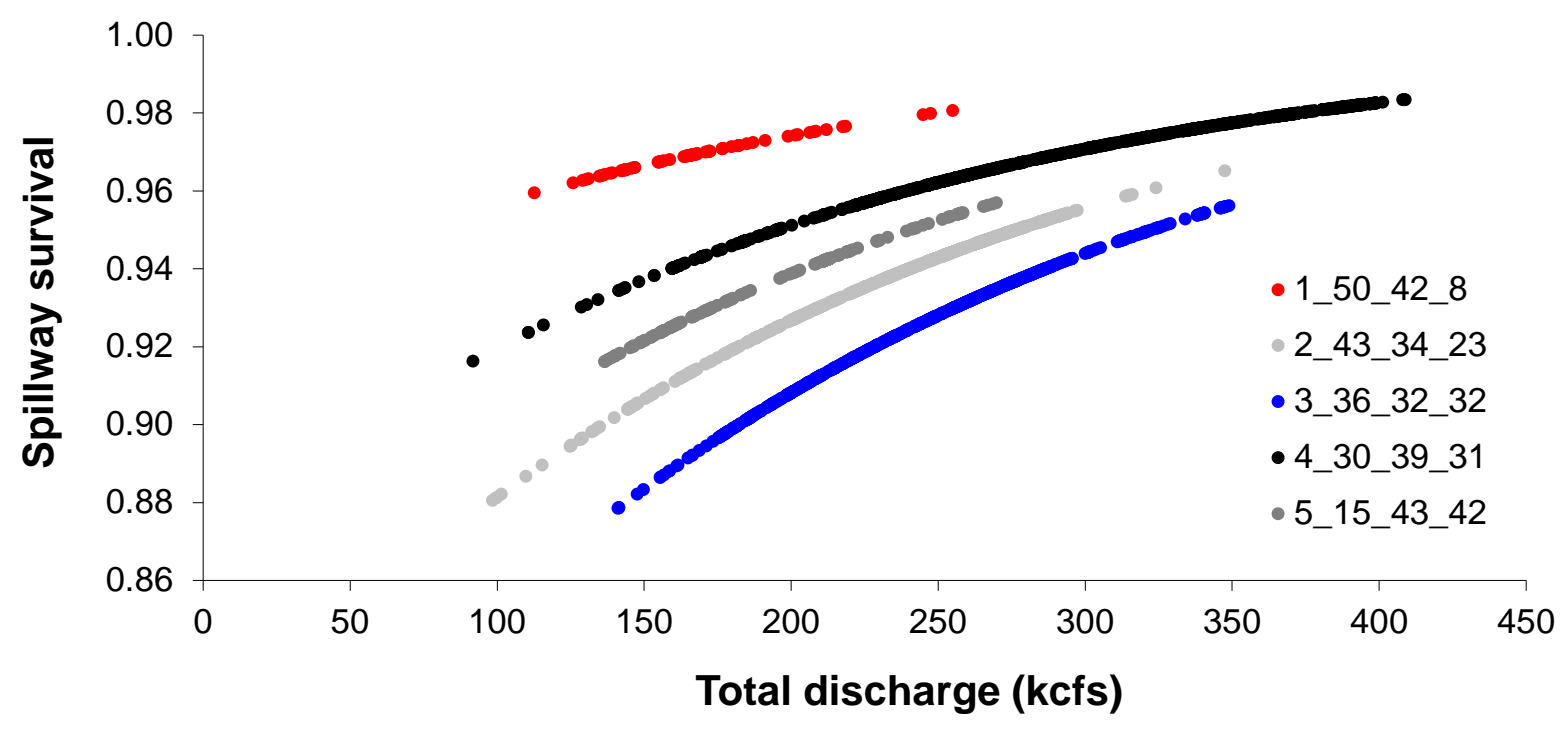

Figure 10. Spillway survival of juvenile steelhead in relation to total discharge for each spill pattern at McNary Dam, 2004-09. Other covariates in the model were held constant at their mean value to examine the relationship to the variable of interest. Legend text identifies the spill pattern number followed by the associated percentage of spill discharge through the south, middle, and north portions of the spillway, respectively. 
Table 14. Model selection for fish that passed through the juvenile bypass system outfall at McNary Dam relating survival ( $\varnothing)$ as a function of individual and group covariates using the fixed structure of the best model for $p$ and $\lambda$ parameters for juvenile steelhead, 2004-09.

[The best-fit models are indicated in bold]

\begin{tabular}{|c|c|c|c|c|}
\hline Model & $\begin{array}{l}\text { Number of } \\
\text { parameters }\end{array}$ & $\mathrm{AIC}_{\mathrm{c}}$ & $\Delta \mathrm{AIC}_{c}$ & Deviance \\
\hline Temperature + Total discharge & 16 & $2,570.27$ & 0.00 & $2,538.04$ \\
\hline Temperature + Spill discharge & 16 & $2,571.48$ & 1.21 & $2,539.25$ \\
\hline Temperature + Spill pattern + Total discharge & 21 & $2,573.29$ & 3.02 & $2,530.90$ \\
\hline Temperature + Spill pattern & 20 & $2,575.11$ & 4.84 & $2,534.75$ \\
\hline Temperature + Percent spill & 16 & $2,576.55$ & 6.28 & $2,544.32$ \\
\hline Temperature & 15 & $2,577.33$ & 7.06 & $2,547.13$ \\
\hline Spill discharge & 15 & $2,577.35$ & 7.08 & $2,547.15$ \\
\hline Spill pattern & 19 & $2,578.16$ & 7.89 & $2,539.84$ \\
\hline Spill pattern + Total discharge & 20 & $2,578.49$ & 8.22 & $2,538.14$ \\
\hline Total discharge & 15 & $2,578.69$ & 8.42 & $2,548.49$ \\
\hline Percent spill & 15 & $2,580.22$ & 9.95 & $2,550.02$ \\
\hline Tag burden & 15 & $2,581.26$ & 10.99 & $2,551.05$ \\
\hline Intercept & 14 & 2,581.33 & 11.06 & $2,553.16$ \\
\hline
\end{tabular}




\section{Subyearling Chinook Salmon}

\section{Survival Analysis}

The best-supported spillway and bypass models for $p$ and $\lambda$ for subyearling Chinook salmon included a year effect for both parameters (table 15). These models of $p$ and $\lambda$ were used for all other spillway and bypass survival analyses.

The best model for describing survival of subyearling Chinook salmon passing through the spillway included spill pattern, tag burden, temperature, spill bay discharge, spillway discharge, and percentage of spill (table 16). Spillway survival was positively related to spill pattern 4 and spillway discharge, but negatively related to all other covariates (table 17). Replacing spillway discharge and percentage of spill in the top model with total discharge resulted in essentially equal support (0.33 $\Delta \mathrm{AIC}_{c}$, table 16). Likewise, replacing tag burden with fish weight or spill bay Q with bay type provided models that fit the data well (1.52 $\Delta \mathrm{AIC}_{c}$ and $0.68 \Delta \mathrm{AIC}_{c}$, respectively, table 16). Spillway survival was highest for spill patterns 4 and 5 , which distributed spill relatively uniformly among the three portions of the spillway, and lowest for spill patterns that discharged more water through the southern spill bays (figs. 11, 12, and 13). Spillway survival decreased for all spill patterns as percentage of spill and spill bay discharge increased (figs. 11 and 13). Conversely, spillway survival increased for all spill patterns as total discharge increased (fig. 12).

Bypass survival of subyearling Chinook salmon was explained best by the model that included temperature, spill pattern, fish weight, total discharge, and the interaction between spill pattern and total discharge (table 18). Bypass survival was negatively related to temperature, and spill patterns 1, 2, and 5, but was positively related to fish weight, total discharge, and spill patterns 3 and 4 (table 17, figs. 14 and 15). The addition of year to the best model decreased $\mathrm{AIC}_{c}$ by 2.39 units. Bypass survival decreased as total discharge increased for the interaction between spill pattern and total discharge for patterns 3 and 4, increased for patterns 1, 2 and 5, and was constant during no-spill conditions (fig. 14). Bypass survival decreased for all spill patterns as temperature increased, and survival was highest for spill patterns 2 and 4 (fig. 15). 
Table 15. Model selection results based on varying $\lambda$ and $p$ with respect to year for subyearling Chinook salmon, 2004-09.

[The best-fit models are indicated in bold. The Phi $(\varnothing)$ portion of the model was held constant for all models of $\lambda$ and $p$. The best-fit model for $\lambda$ was determined first and then used to assess the best-fit model for $p . \varnothing$, the probability of survival from dam passage through a route to the first downstream detection array; $p$, the probability of being detected at the first downstream detection array given the individual survived; $\lambda$, the joint probability of surviving and being detected from the first downstream array to the next downstream array; g, all combinations of the photoperiod, passage location, bay type, spill pattern, and year group covariates; y, year]

\begin{tabular}{|c|c|c|c|c|c|}
\hline & Model & $\begin{array}{l}\text { Number of } \\
\text { parameters }\end{array}$ & $\mathrm{AIC}_{c}$ & $\Delta \mathrm{AlC}_{c}$ & Deviance \\
\hline \multicolumn{6}{|c|}{ Spillway } \\
\hline 1 & $\varnothing(\mathrm{g}) p(\mathrm{y}) \lambda(\mathrm{y})$ & 123 & $8,544.86$ & 0.00 & $8,294.55$ \\
\hline 2 & $\varnothing(\mathrm{g}) p(\mathrm{y}) \lambda$ & 120 & $8,621.33$ & 76.46 & $8,377.23$ \\
\hline 3 & $\varnothing(\mathrm{g}) p \lambda(\mathrm{y})$ & 120 & $9,274.83$ & 729.97 & $9,030.73$ \\
\hline \multicolumn{6}{|c|}{ Bypass } \\
\hline 1 & $\varnothing(\mathrm{g}) p(\mathrm{y}) \lambda(\mathrm{y})$ & 57 & 4,124.33 & 0.00 & $4,008.13$ \\
\hline 2 & $\varnothing(\mathrm{g}) p(\mathrm{y}) \lambda$ & 52 & $4,192.13$ & 67.80 & $4,086.30$ \\
\hline & $\varnothing(\mathrm{g}) p \lambda(\mathrm{y})$ & 52 & 4,391.08 & 266.75 & $4,285.25$ \\
\hline
\end{tabular}


Table 16. Model selection for fish that passed through the spillway at McNary Dam relating survival (ø) as a function of individual and group covariates using the fixed structure of the best model for $p$ and $\lambda$ parameters for subyearling Chinook salmon, 2004-09.

[The best-fit models are indicated in bold. Q, discharge; PassLoc, passage location; Temp, temperature]

\begin{tabular}{|c|c|c|c|c|}
\hline Model & $\begin{array}{l}\text { Number of } \\
\text { parameters }\end{array}$ & $\mathrm{AlC}_{c}$ & $\Delta \mathrm{AlC}_{c}$ & Deviance \\
\hline Spill pattern + Tag burden + Temp + Spill bay Q + Spill $\mathbf{Q}+$ Percent spill & 20 & 8,406.22 & 0.00 & $8,366.10$ \\
\hline Spill pattern + Tag burden + Temp + Spill bay Q + Total $Q$ & 19 & $8,406.55$ & 0.33 & $8,368.45$ \\
\hline Spill pattern + Tag burden + Temp + Spill bay $\mathbf{Q}+$ Spill $\mathbf{Q}+$ Percent spill + PassLoc & 22 & $8,406.59$ & 0.37 & $8,362.45$ \\
\hline Spill pattern + Tag burden + Temp + Bay type + Total Q & 19 & $8,406.90$ & 0.68 & $8,368.80$ \\
\hline Spill pattern + Fish weight + Temp + Spill bay Q + Total Q & 19 & 8,407.74 & 1.52 & 8,369.64 \\
\hline Spill pattern + Tag burden + Temp + Spill bay $\mathbf{Q}+$ Total $\mathbf{Q}+$ Spill pattern*Total $\mathbf{Q}$ & 23 & 8,408.18 & 1.97 & $8,362.03$ \\
\hline Spill pattern + Tag burden + Temp + Total Q & 18 & $8,408.57$ & 2.35 & $8,372.47$ \\
\hline Spill pattern + Tag burden + Temp + Bay type + Total Q + Total Q*spill pattern & 23 & $8,408.65$ & 2.44 & $8,362.50$ \\
\hline Tag burden + Temp + Bay type + Total Q & 15 & $8,410.22$ & 4.00 & $8,380.15$ \\
\hline Spill pattern + Temp + Spill bay Q + Total Q & 18 & $8,410.46$ & 4.25 & $8,374.37$ \\
\hline Spill pattern + Temp + Spill bay Q + Total Q + PassLoc & 20 & $8,410.51$ & 4.29 & $8,370.39$ \\
\hline Spill pattern + Temp + Bay type + Total Q & 18 & $8,410.64$ & 4.42 & $8,374.54$ \\
\hline Spill pattern + Temp + Spill bay Q + Spill Q + Percent spill & 19 & $8,410.67$ & 4.45 & $8,372.56$ \\
\hline Spill pattern + Tag burden + Temp + Spill bay Q + Total Q + Spill pattern*Spill bay Q & 23 & $8,411.15$ & 4.93 & $8,365.00$ \\
\hline
\end{tabular}


Table 16. Model selection for fish that passed through the spillway at McNary Dam relating survival (ø) as a function of individual and group covariates using the fixed structure of the best model for $p$ and $\lambda$ parameters for subyearling Chinook salmon, 2004-09.-Continued

[Q, discharge; PassLoc, passage location; Temp, temperature]

\begin{tabular}{|c|c|c|c|c|}
\hline Model & $\begin{array}{l}\text { Number of } \\
\text { parameters }\end{array}$ & $\mathrm{AlC}_{c}$ & $\Delta \mathrm{AlC}_{c}$ & Deviance \\
\hline Tag burden + Temp + Spill bay Q + Spill Q + Percent spill & 16 & $8,411.27$ & 5.05 & 8,379.19 \\
\hline Spill pattern + Temp + Bay type + Total Q + PassLoc & 20 & $8,411.31$ & 5.10 & $8,371.20$ \\
\hline PassLoc + Temp + Spill bay Q + Spill Q + Percent spill + Tag burden & 18 & $8,411.64$ & 5.42 & $8,375.54$ \\
\hline Tag burden + Temp + Spill Q + Total Q + PassLoc + PassLoc*Spill Q & 19 & $8,411.67$ & 5.45 & 8,373.56 \\
\hline Tag burden + Temp + Spill Q + Total Q & 15 & $8,411.74$ & 5.53 & $8,381.68$ \\
\hline Tag burden + Temp + Spill Q + Total Q + PassLoc & 17 & $8,412.35$ & 6.13 & 8,378.27 \\
\hline Spill pattern + Temp + Total Q & 17 & $8,412.42$ & 6.21 & $8,378.34$ \\
\hline Tag burden + Temp + Spill bay Q + Spill Q + Percent spill + PassLoc + PassLoc*Spill bay Q & 20 & $8,412.64$ & 6.43 & $8,372.53$ \\
\hline Temp + Bay type + Total Q & 14 & $8,414.26$ & 8.04 & 8,386.20 \\
\hline Temp + Spill bay Q + Spill Q + Percent spill & 15 & $8,415.37$ & 9.15 & $8,385.30$ \\
\hline Temp + Bay type + Total Q + PassLoc & 16 & $8,415.58$ & 9.36 & $8,383.50$ \\
\hline Temp + Spill Q + Total Q + PassLoc + PassLoc*Spill Q & 18 & $8,415.63$ & 9.41 & $8,379.53$ \\
\hline Temp + Spill bay Q + Spill Q + Percent spill + PassLoc & 17 & $8,415.65$ & 9.43 & $8,381.56$ \\
\hline
\end{tabular}


Table 17. Slope $(\beta)$ coefficients, standard error, and 95-percent confidence limits of model parameters for subyearling Chinook salmon passing McNary Dam, 2004-09.

[CL, confidence limit. The addition of year improved model fit for bypass survival]

\begin{tabular}{|c|c|c|c|c|}
\hline Variable & $\beta$ & $\begin{array}{l}\text { Standard } \\
\text { Error }\end{array}$ & Lower CL & Upper CL \\
\hline \multicolumn{5}{|c|}{ Spillway } \\
\hline Intercept (spill pattern 2) & 8.054 & 1.212 & 5.679 & 10.429 \\
\hline Spill pattern 4 & 0.313 & 0.173 & -0.026 & 0.651 \\
\hline Spill pattern 5 & -0.372 & 0.172 & -0.710 & -0.035 \\
\hline Spill pattern 1 & -0.480 & 0.220 & -0.912 & -0.048 \\
\hline Spill pattern 3 & -1.212 & 0.592 & -2.372 & -0.052 \\
\hline Temperature & -0.235 & 0.055 & -0.343 & -0.128 \\
\hline Spill discharge & 0.013 & 0.004 & 0.006 & 0.021 \\
\hline Spill bay discharge & -0.048 & 0.024 & -0.095 & 0.000 \\
\hline Percent spill & -0.033 & 0.009 & -0.050 & -0.016 \\
\hline Tag burden & -0.170 & 0.068 & -0.303 & -0.038 \\
\hline \multicolumn{5}{|c|}{ Bypass } \\
\hline Intercept & 9.271 & 1.901 & 5.545 & 12.997 \\
\hline Temperature & -0.434 & 0.082 & -0.595 & -0.274 \\
\hline Fish weight & 0.025 & 0.016 & -0.007 & 0.057 \\
\hline Total discharge & 0.001 & 0.004 & -0.008 & 0.009 \\
\hline Spill pattern 1 & -0.842 & 1.758 & -4.288 & 2.604 \\
\hline Spill pattern 2 & -1.368 & 1.178 & -3.676 & 0.941 \\
\hline Spill pattern 3 & 6.118 & 7.192 & -7.979 & 20.214 \\
\hline Spill pattern 4 & 2.807 & 0.996 & 0.854 & 4.759 \\
\hline Spill pattern 5 & -0.956 & 1.227 & -3.361 & 1.450 \\
\hline Spill pattern $1 *$ total discharge & 0.003 & 0.011 & -0.018 & 0.024 \\
\hline Spill pattern $2 *$ total discharge & 0.009 & 0.007 & -0.005 & 0.022 \\
\hline Spill pattern $3 *$ total discharge & -0.038 & 0.039 & -0.113 & 0.038 \\
\hline Spill pattern $4 *$ total discharge & -0.011 & 0.005 & -0.021 & -0.001 \\
\hline Spill pattern $5 *$ total discharge & 0.006 & 0.007 & -0.009 & 0.020 \\
\hline
\end{tabular}




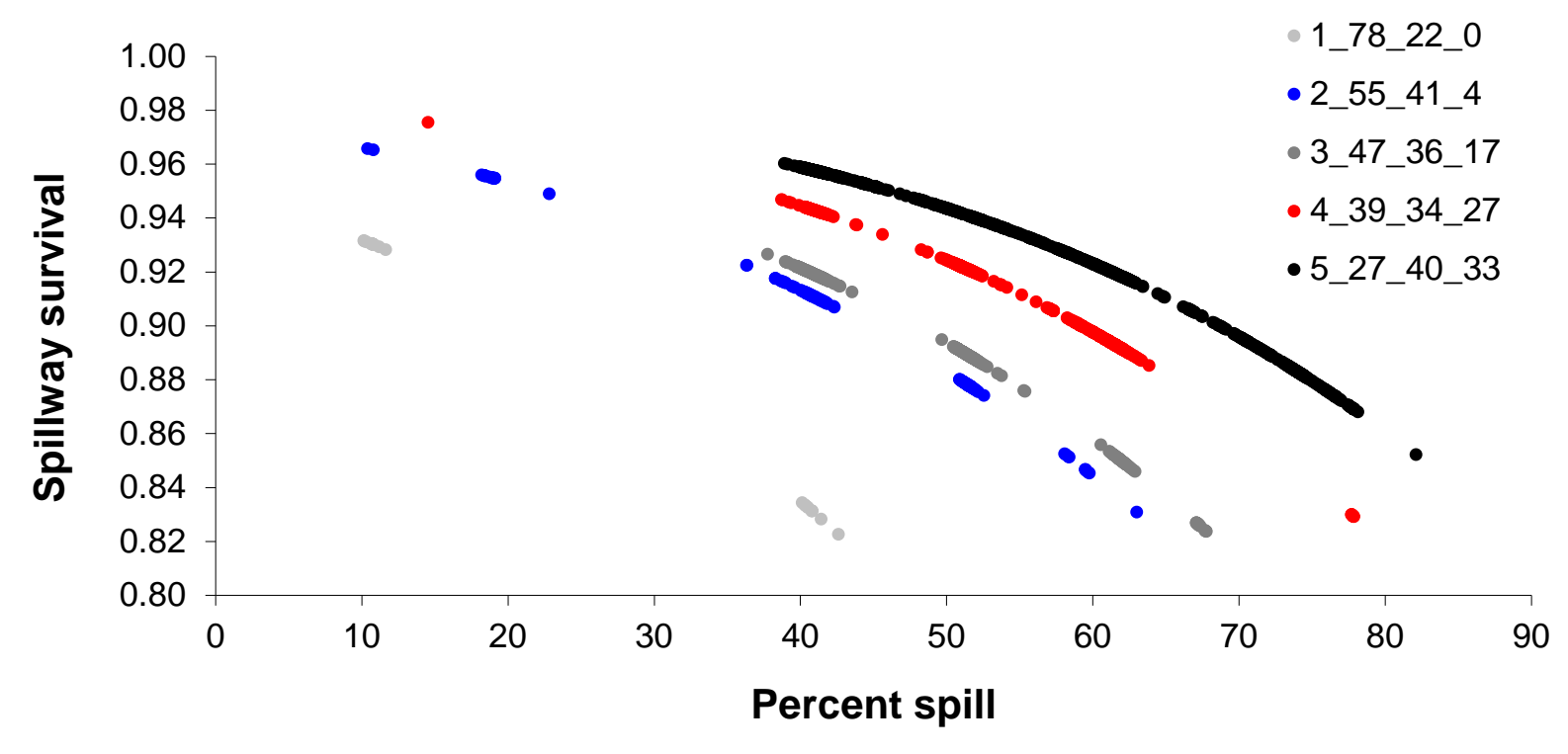

Figure 11. Spillway survival of subyearling Chinook salmon in relation to percent spill for each spill pattern at McNary Dam, 2004-09. Other covariates in the model were held constant at their mean value to examine the relationship to the variable of interest. Legend text identifies the spill pattern number followed by the associated percentage of spill discharge through the south, middle, and north portions of the spillway, respectively. 


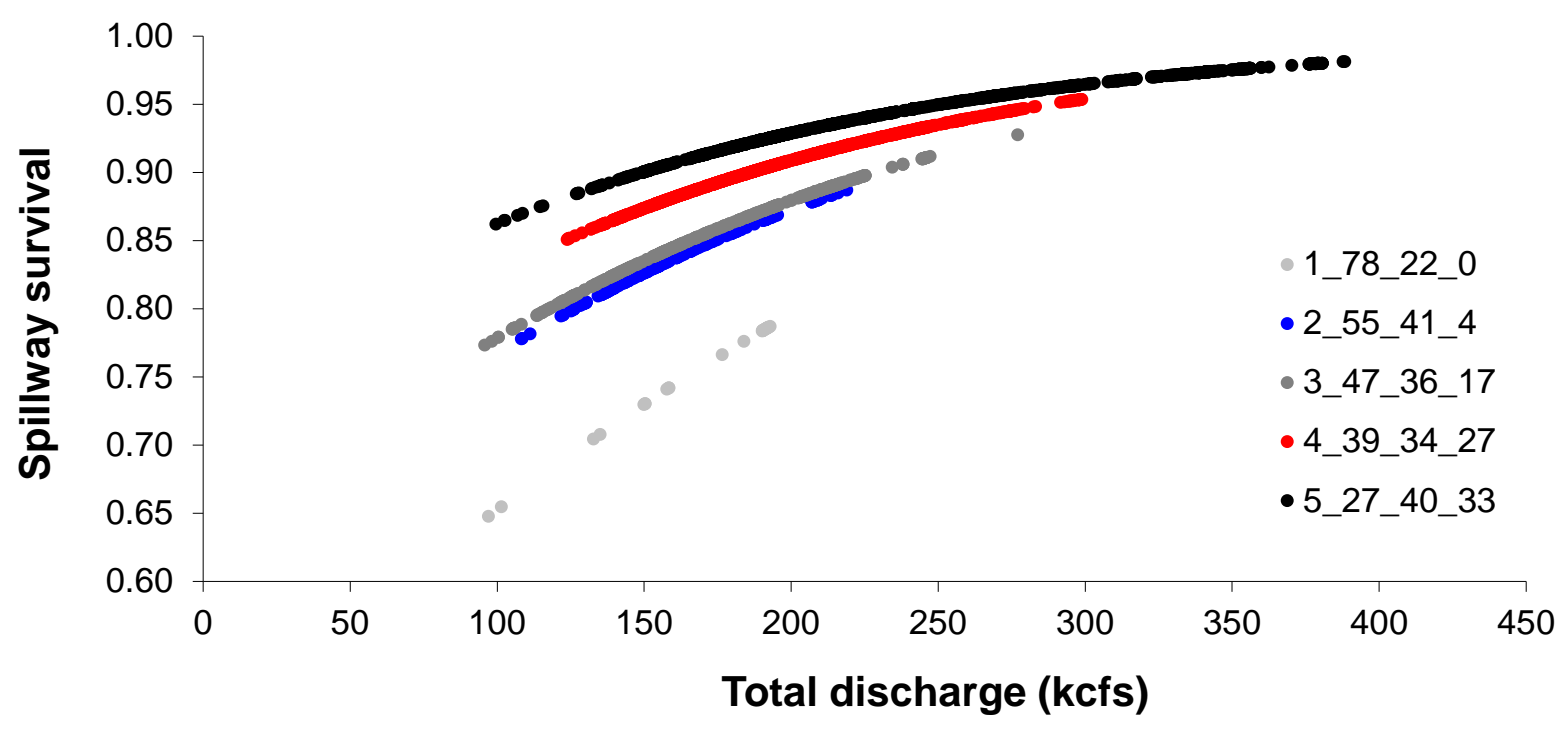

Figure 12. Spillway survival of subyearling Chinook salmon in relation to total discharge for each spill pattern at McNary Dam, 2004-09. Other covariates in the model were held constant at their mean value to examine the relationship to the variable of interest. Legend text identifies the spill pattern number followed by the associated percentage of spill discharge through the south, middle, and north portions of the spillway, respectively. 


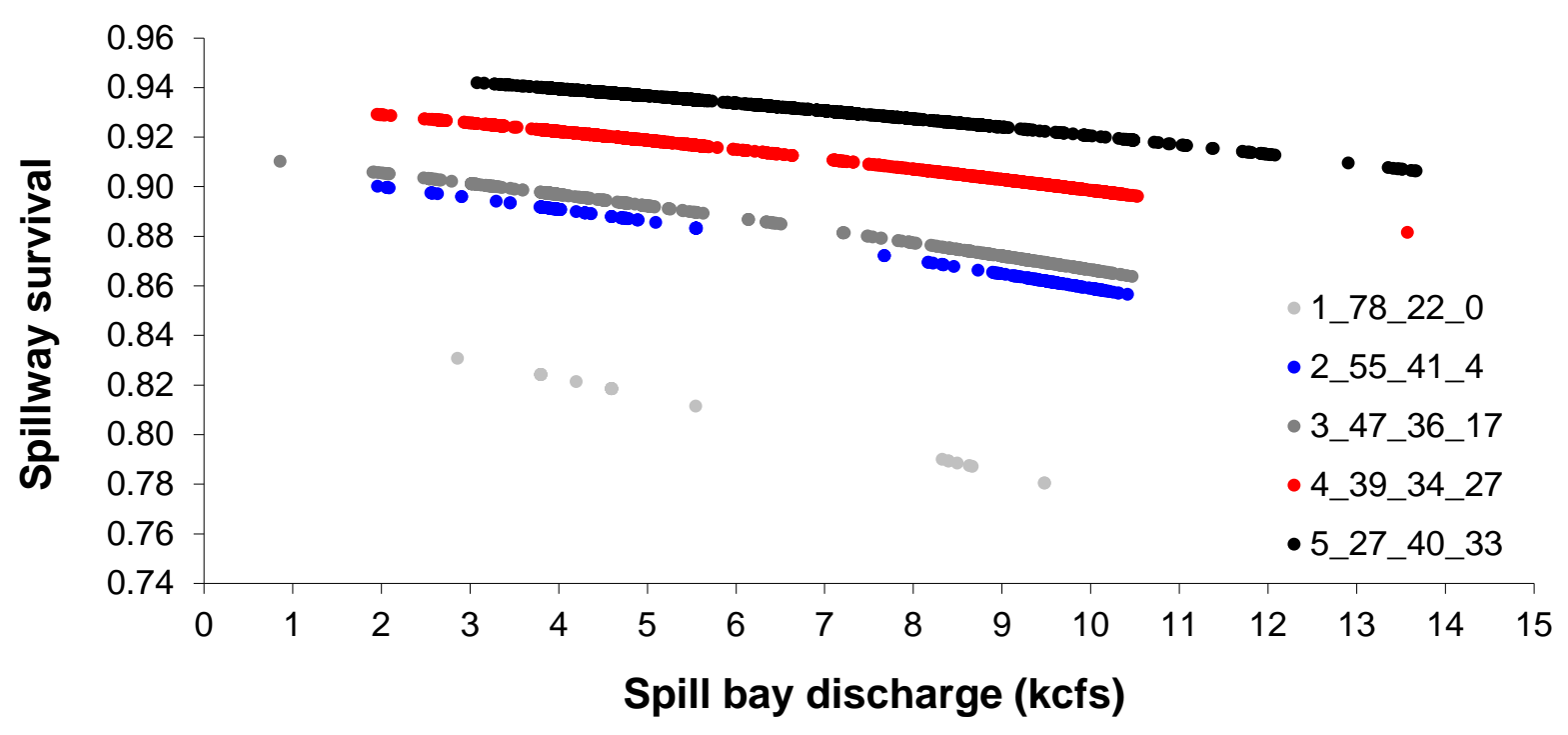

Figure 13. Spillway survival of subyearling Chinook salmon in relation to total discharge for each spill pattern at McNary Dam, 2004-09. Other covariates in the model were held constant at their mean value to examine the relationship to the variable of interest. Legend text identifies the spill pattern number followed by the associated percentage of spill discharge through the south, middle, and north portions of the spillway, respectively. 
Table 18. Model selection for fish that passed through the juvenile bypass system outfall at McNary Dam relating survival (ø) as a function of individual and group covariates using the fixed structure of the best model for $p$ and $\lambda$ parameters for subyearling Chinook salmon, 2004-09.

[The best-fit models are indicated in bold. Q, discharge]

\begin{tabular}{|c|c|c|c|c|}
\hline Model & $\begin{array}{l}\text { Number of } \\
\text { parameters }\end{array}$ & $\mathrm{AIC}_{c}$ & $\Delta \mathrm{AlC}_{c}$ & Deviance \\
\hline Temperature + Spill pattern + Fish weight + Total Q + Spill pattern*Total $\mathbf{Q}^{1}$ & 26 & $4,062.74$ & 0.00 & $4,010.28$ \\
\hline Temperature + Spill pattern + Total Q + Spill pattern*Total Q & 25 & $4,063.24$ & 0.50 & $4,012.81$ \\
\hline Temperature + Spill pattern + Fish weight & 20 & $4,065.41$ & 2.67 & $4,025.13$ \\
\hline Temperature + Spill pattern & 19 & $4,066.09$ & 3.35 & $4,027.84$ \\
\hline Temperature + Fish weight & 15 & $4,067.41$ & 4.67 & $4,037.25$ \\
\hline Temperature & 14 & $4,067.56$ & 4.82 & $4,039.43$ \\
\hline
\end{tabular}

${ }^{1}$ Addition of year to this model decreased AIC $_{\mathrm{c}}$ by 2.39 . 


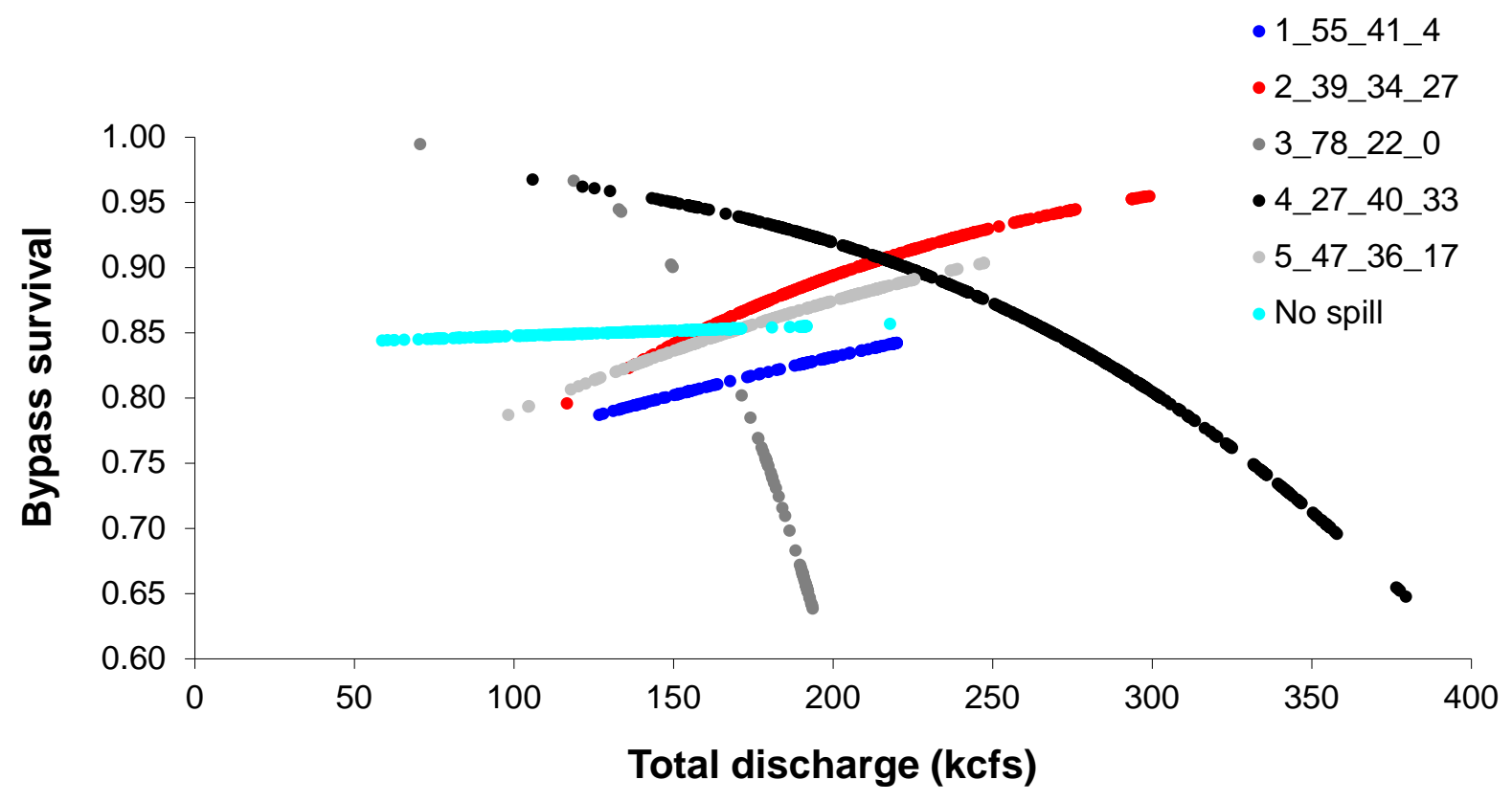

Figure 14. Bypass survival of subyearling Chinook salmon in relation to total discharge, with an interaction between spill pattern and total discharge, for each spill pattern at McNary Dam, 2004-09. Other covariates in the model were held constant at their mean value to examine the relationship to the variable of interest. Legend text identifies the spill pattern number followed by the associated percentage of spill discharge through the south, middle, and north portions of the spillway, respectively. 


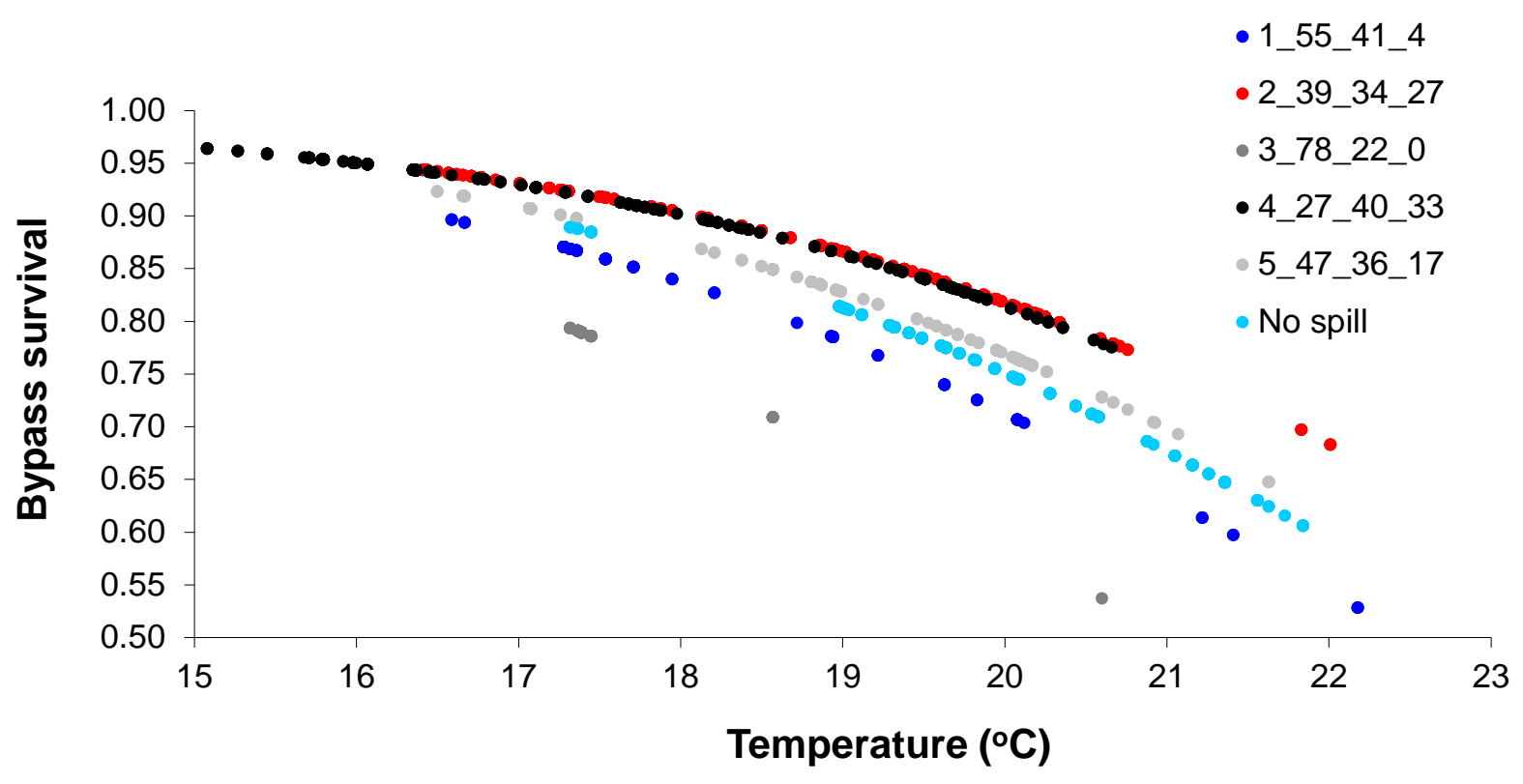

Figure 15. Bypass survival of subyearling Chinook salmon in relation to water temperature at McNary Dam, 200409. Other covariates in the model were held constant at their mean value to examine the relationship to the variable of interest. Legend text identifies the spill pattern number followed by the associated percentage of spill discharge through the south, middle, and north portions of the spillway, respectively. 


\section{Sockeye Salmon}

\section{Survival Analysis}

Initial analyses of $\lambda$ and $p$ models for sockeye salmon passing through the spillway indicated that $\lambda$ was best fit with year and tag burden covariate effects and $p$ was best fit with a year effect (table 19). However, because of low downstream detection probabilities for sockeye salmon in most years, survival probabilities for many models, including spill pattern, using this $p$ model were not estimable. In order to analyze the effect of spill pattern on survival, we chose to use a model of $\lambda$ and $p$ with only the spill pattern effect for the analyses.

The best model for describing survival of sockeye salmon passing through the spillway included passage location, spill discharge, temperature, and tag burden (table 20). Spillway survival was positively related to passage location and temperature, but negatively related to spill discharge and tag burden (table 21). The model that replaced spill discharge with total discharge and percentage of spill also was well supported (1.83 $\Delta \mathrm{AIC}_{c}$, table 20). The addition of year to the top model improved the model substantially, decreasing $\Delta \mathrm{AIC}_{c}$ by 109.61 (table 20). Regardless of spill passage location, spillway survival decreased as spillway discharge or total discharge increased, and survival was highest for fish passing through north spill bays and lowest for fish passing through the middle portion of the spillway (figs. 16 and 17). Spillway survival was more than 98 percent for all spill passage locations at 75 kcfs spillway discharge and decreased to between 81 and 92 percent, depending on spill-passage location (fig. 16). Spillway survival was 96 percent or more for all spill passage locations at about 200 kcfs total discharge, but steadily decreased to between 86 and 94 percent at 425 kcfs (fig. 17).

Table 19. Model selection results for sockeye salmon passing through the spillway based on varying $\lambda$ and $p$ with respect to year, 2004-09.

[The best-fit models are indicated in bold. The Phi $(\varnothing)$ portion of the model was held constant for all models of $\lambda$ and $p$. The best-fit model for $\lambda$ was determined first and then used to assess the best-fit model for $p$. $\varnothing$, the probability of survival from dam passage through a route to the first downstream detection array; $p$, the probability of being detected at the first downstream detection array given the individual survived; $\lambda$, the joint probability of surviving and being detected from the first downstream array to the next downstream array; g, all combinations of the photoperiod, passage location, bay type, spill pattern, and year group covariates; y, year]

\begin{tabular}{llcccc}
\hline \multicolumn{1}{c}{ Model } & $\begin{array}{c}\text { Number of } \\
\text { parameters }\end{array}$ & AIC $_{\boldsymbol{c}}$ & \multicolumn{1}{c}{$\Delta$ AIC $_{\boldsymbol{c}}$} & Deviance \\
\hline $\mathbf{1}$ & $\boldsymbol{\varnothing ( \mathrm { g } )} \boldsymbol{p}(\mathbf{y}) \lambda(\mathbf{y}+\mathbf{t a g}$ burden) & $\mathbf{5 4}$ & $\mathbf{3 , 9 4 5 . 8 9}$ & $\mathbf{0 . 0 0}$ & $\mathbf{3 , 8 3 6 . 5 7}$ \\
2 & $\varnothing(\mathrm{g}) p(\mathrm{y}) \lambda(\mathrm{y})$ & 53 & $3,949.13$ & 3.25 & $3,841.87$ \\
3 & $\varnothing(\mathrm{g}) p(\mathrm{y}) \lambda$ & 50 & $4,015.40$ & 69.52 & $3,914.28$ \\
4 & $\varnothing(\mathrm{g}) p \lambda(\mathrm{y})$ & 50 & $5,721.43$ & $1,775.54$ & $5,620.30$ \\
\hline
\end{tabular}


Table 20. Model selection for fish that passed through the spillway at McNary Dam relating survival (ø) as a function of individual and group covariates using the fixed structure of the best model for $p$ and $\lambda$ parameters for sockeye salmon, 2004-09.

[The best-fit models are indicated in bold]

\begin{tabular}{|c|c|c|c|c|}
\hline Model & $\begin{array}{l}\text { Number of } \\
\text { parameters }\end{array}$ & $\mathrm{AIC}_{c}$ & $\Delta \mathrm{AlC}_{c}$ & Deviance \\
\hline Passage location + Spill discharge + Temperature + Tag burden $^{1}$ & 13 & $5,171.48$ & 0.00 & $5,145.40$ \\
\hline Passage location + Total discharge + Temperature + Percent spill + Tag burden & 14 & $5,173.31$ & 1.83 & $5,145.22$ \\
\hline Passage location + Total discharge + Temperature + Tag burden & 13 & $5,174.16$ & 2.68 & $5,148.08$ \\
\hline Passage location + Percent spill + Temperature + Tag burden & 14 & $5,175.61$ & 4.13 & $5,147.52$ \\
\hline Passage location + Spill discharge + Tag burden & 12 & $5,178.99$ & 7.51 & $5,154.92$ \\
\hline Spill discharge + Temperature + Tag burden & 11 & $5,179.32$ & 7.84 & $5,157.26$ \\
\hline Total discharge + Temperature + Percent spill + Tag burden & 12 & $5,181.19$ & 9.71 & $5,157.12$ \\
\hline
\end{tabular}

${ }^{1}$ Addition of year to this model decreased $\mathrm{AIC}_{\mathrm{c}}$ by 109.606. 
Table 21. Slope ( $\beta$ ) coefficients, standard error, and 95-percent confidence limits of model parameters for sockeye salmon passing through the spillway at McNary Dam, 2004-09.

[CL, confidence limit]

\begin{tabular}{lcccc}
\hline \multicolumn{1}{c}{ Variable } & $\boldsymbol{\beta}$ & $\begin{array}{c}\text { Standard } \\
\text { error }\end{array}$ & Lower CL & Upper CL \\
\hline Intercept (middle passage location) & 1.517 & 1.861 & -2.130 & 5.164 \\
North passage location & 0.755 & 0.303 & 0.162 & 1.349 \\
South passage location & 0.448 & 0.164 & 0.127 & 0.769 \\
Spill discharge & -0.014 & 0.003 & -0.019 & -0.008 \\
Temperature & 0.379 & 0.123 & 0.137 & 0.621 \\
Tag burden & -0.439 & 0.082 & -0.601 & -0.278 \\
\hline
\end{tabular}




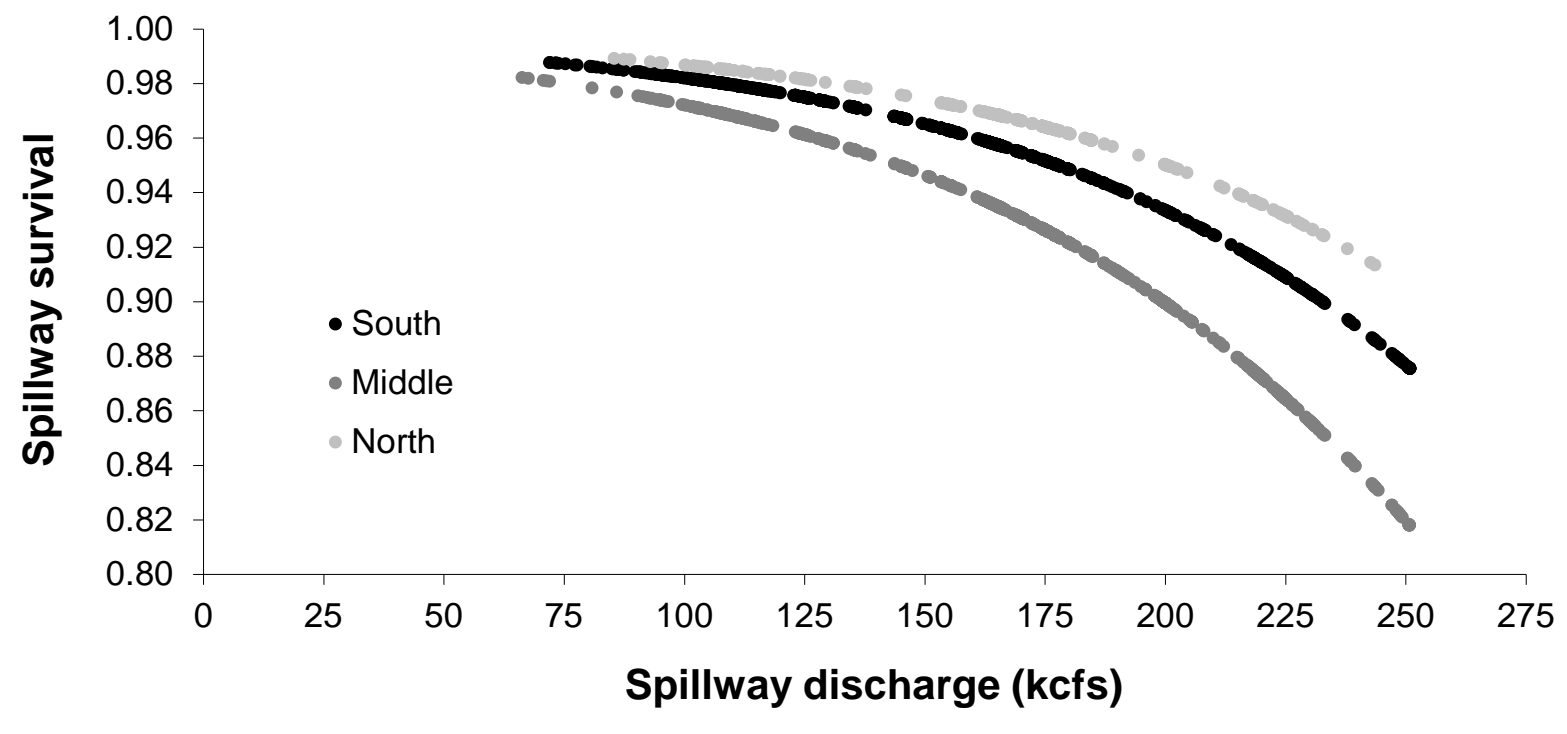

Figure 16. Spillway survival of sockeye salmon in relation to spillway discharge for each spillway passage location at McNary Dam, 2004-09. Other covariates in the model were held constant at their mean value to examine the relationship to the variable of interest. 


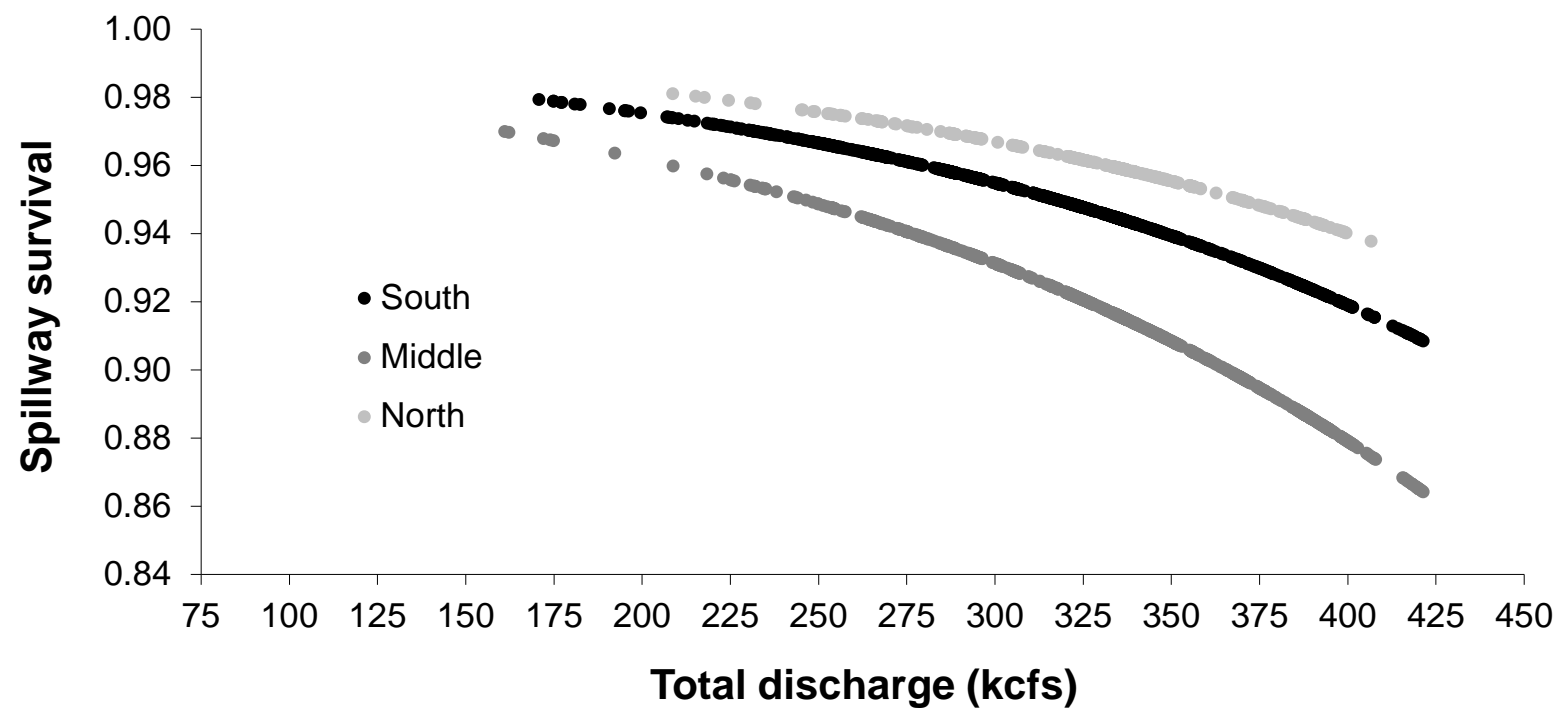

Figure 17. Spillway survival of sockeye salmon in relation to total discharge for each spillway passage location at McNary Dam, 2004-09. Other covariates in the model were held constant at their mean value to examine the relationship to the variable of interest. 


\section{Discussion}

\section{Spillway Survival}

This analysis provided many models that explained variation in spillway survival of juvenile salmonids passing McNary Dam. Models supported by the data included spillway-related variables, as well as other variables. Predominant variables unrelated to spill bay operations that influenced spillway survival were water temperature, tag burden, and total discharge. Water temperature was a factor in nearly all supported models for all species with survival being inversely related to increasing temperatures. Tag burden also was a factor in nearly all supported models for all species except juvenile steelhead, and also was negatively related to survival. Although tag burden was not a supported factor in models for steelhead, fish weight was supported in most models for steelhead. Total discharge was not a factor in the best models for spillway survival for yearling Chinook salmon, but was a factor in many supportive models for juvenile steelhead, subyearling Chinook salmon, and sockeye salmon.

Predominant variables related to spill bay operations that influenced spillway survival were spill pattern, spillway discharge, spill bay discharge, bay type, and spill passage location. The combination of these factors in the models, and the extent to which they influenced survival, varied by species. Both spill bay discharge and bay type were factors in the best three models for yearling Chinook salmon. Spillway survival was positively related to an increase in spill bay discharge. Survival was higher for yearling Chinook salmon passing through conventional spill bays, compared to TSW bays, for all spill bay discharge levels. Although spill pattern was not a factor in models for yearling Chinook salmon, we analyzed spillway survival by spill pattern for comparison with other species and found that spill pattern 1 (predominantly south spill) provided the highest survival, similar to steelhead. The addition of a year factor did not improve any models for yearling Chinook salmon, suggesting that the covariates included in the models adequately captured the factors that cause year-to-year variation in survival.

The best model for steelhead included spillway discharge that was positively related to spillway survival. The next best model (within $1.81 \mathrm{AIC}_{\mathrm{c}}$ ) replaced spillway discharge with spill pattern and total discharge. Similar to yearling Chinook salmon, spillway survival increased as total discharge increased, and survival was highest for spill pattern 1 , which discharged spill predominantly through the south portion of the spillway. The addition of a year factor improved the top three models for steelhead, indicating there are some other variables not included in our analysis that might be influencing year-toyear variation in survival for steelhead (for example, fish condition or disease).

Spill pattern was the most predominant factor related to spill bay operations in supportive models for subyearling Chinook salmon spillway survival, followed by spill bay discharge, spill discharge, and percentage of spill. We found that spillway survival decreased for subyearling Chinook salmon as percentage of spill or spill bay discharge increased. Conversely, spillway survival increased as total discharge increased. Uniform spill patterns (patterns 4 and 5) provided higher survival than spill patterns that discharged most water through southern spill bays (patterns 1-3), and pattern 5 provided the highest survival. This result for summer migrating subyearling Chinook salmon was the opposite of what we found for spring migrants, which had higher survival for southern spill patterns. The addition of a year factor to the best models did not explain any further variability in spillway survival for subyearling Chinook salmon.

The variables related to spill bay operations that were in the best models for sockeye salmon included spillway passage location and spillway discharge. Spillway survival was negatively related to an increase in both spillway discharge and total discharge. Spillway survival was highest for sockeye salmon passing through the north portion of the spillway, followed by the middle and south locations. The addition of a year factor improved the best model for sockeye salmon, indicating there are some 
other variables not included in our analysis that might be influencing year-to-year variation in spillway survival. Because sockeye salmon, unlike the other species, were released 167-358 km upstream of McNary Dam, tag life may have been an issue with this species. Obviously, maximum travel times of tagged study fish should be shorter than the minimum tag life of tags used in the study. We found that maximum travel times of fish detected at the first site downstream of McNary Dam did not exceed the expected tag life for tags used in 2008 and 2009 (17 and 22 days, respectively). However, maximum travel times did exceed tag life for tags used in 2006 and 2007 (14 days). This suggests the likelihood that there were some tagged fish for which tags expired prematurely, indicating the potential for bias in survival estimates for sockeye salmon. It also provides a possible explanation for why year improved the best model for spillway survival.

\section{Bypass Survival}

Compared to models for spillway survival, fewer models were identified by this analysis that explain variation in survival of juvenile salmonids passing through the juvenile bypass system outfall at McNary Dam. Further, few models contained covariates related to spill bay operations. Photoperiod was the only factor in the best and only model that had support for bypass survival of yearling Chinook salmon. No other models were within $2 \mathrm{AIC}_{\mathrm{c}}$ units except for the intercept model $\left(1.12 \Delta \mathrm{AIC}_{c}\right)$. Bypass survival of yearling Chinook salmon was lower during the day, compared to night, which is consistent with results reported by Adams and others (2011). Temperature was a predominant variable in all models describing bypass survival for both juvenile steelhead and subyearling Chinook salmon, similar to models for spillway survival. Spillway discharge and spill pattern were the only covariates related to spill bay operations that were present in supportive models for bypass survival of juvenile steelhead and subyearling Chinook salmon, respectively. Spillway discharge was found only in the second-best model for juvenile steelhead, and spill pattern was a predominant factor for subyearling Chinook salmon bypass survival in the top four models. 


\section{Spillway and Bypass Survival}

The results of these analyses, while they were not designed to yield predictive models, can be used to help develop dam-operation strategies that optimize juvenile salmonid survival. For example, increasing total discharge typically had a positive effect on both spillway and bypass survival for all species except sockeye salmon. Likewise, an increase in spill bay discharge improved spillway survival for yearling Chinook salmon, and an increase in spillway discharge positively affected spillway survival for juvenile steelhead. The strong positive relation between spill and survival indicates that increasing the amount of water through the spillway is one strategy that could be used to improve spillway survival for yearling Chinook salmon and juvenile steelhead. However, increased spill did not improve spillway survival for subyearling Chinook salmon and sockeye salmon. Our results indicate that a uniform spill pattern would provide the highest spillway survival and bypass survival for subyearling Chinook salmon. Conversely, a predominantly south spill pattern provided the highest spillway survival for yearling Chinook salmon and juvenile steelhead. Although spill pattern was not a factor for spillway survival of sockeye salmon, spill bay operations that optimize passage through the north and south spill bays maximized spillway survival for this species. Bypass survival of yearling Chinook salmon could be improved by optimizing conditions to facilitate bypass passage at night, but the method to do so is not apparent from this analysis because photoperiod was the only factor affecting bypass survival based on the best and only supported model. Bypass survival of juvenile steelhead would benefit from lower water temperatures and increased total and spillway discharge. Likewise, subyearling Chinook salmon bypass survival would improve with lower water temperature and increased total discharge with a uniform spill pattern. When total discharge is high (greater than $200 \mathrm{kcfs}$ ), there may be a benefit to having more of the flow in the spillway discharged in the bays closest to the powerhouse (south spill). This spill pattern may inhibit the potential for an eddy that could cause fish passing through the bypass pipe to be pulled back upstream into the tailrace of the powerhouse. When total discharge is low (less than $200 \mathrm{kcfs}$ ) and the amount of water passing through the powerhouse is proportionally higher than water passing the spillway, survival may be improved by having a uniform spill pattern compared to a pattern that passed more water through the southern spill bays. Having more water passing through the southern spill bays when the predominant flow is being discharged through the powerhouse may cause eddies in the north portion of the spillway and could cause a decrease in survival.

These analyses provided a unique opportunity to examine data from multiple years of research to investigate factors influencing spillway and bypass survival at McNary Dam. By first using statistical models to select among variables hypothesized to influence survival, and then quantifying the magnitude of the effects, we were able to examine how changes to dam operations might positively or negatively influence survival. This is critical information that managers need to develop long-term operational plans. Although development of predictive models was beyond the scope of our analysis, the relations we identified could be used to develop simulation models to gauge the effect of management actions on dam survival. 


\section{References Cited}

Adams, N.S., and Counihan, T.D., eds., 2009, Survival and migration behavior of juvenile salmonids at McNary Dam, 2007: U.S. Geological Survey Report to the U.S. Army Corps of Engineers, Walla Walla District, Washington, Contract W68SBV70178419.

Adams, N.S., and Evans, S.D., eds., 2011, Summary of juvenile salmonid passage and survival at McNary Dam-Acoustic survival studies 2006-09: U.S. Geological Survey Open-File Report 20111179, $144 \mathrm{p}$.

Adams, N.S., and Liedtke, T.L., eds., 2009, Juvenile salmonid survival, passage, and egress at McNary Dam during tests of temporary spillway weirs, 2008: U.S. Geological Survey Report to the U. S. Army Corps of Engineers, Walla Walla District, Washington, Contract W68SBV80448890.

Adams, N.S., and Liedtke, T.L., eds., 2010, Juvenile salmonid survival, passage, and egress at McNary Dam during tests of temporary spillway weirs, 2009: U.S. Geological Survey Report to the U.S. Army Corps of Engineers, Walla Walla District, Washington, Contract W68SBV90070150.

Adams, N.S., Plumb, J.M., Hatton, T.W., Jones, E.C., Swyers, N.M., Sholtis, M.D., Reagan, R.E., and Cash, K.M., 2008, Survival and migration behavior of juvenile salmonids at McNary Dam, 2006: U.S. Geological Survey Annual Report to the U. S. Army Corps of Engineers, Walla Walla District, Report No. 2006-W68SBV60478899.

Adams, N.S., Rondorf, D.W, Evans, S.D., Kelly, J.E., and Perry, R.W., 1998, Effects of surgically and gastrically implanted radio transmitters on growth and feeding behavior of juvenile Chinook salmon: Transactions of the American Fisheries Society, v. 127, p. 128-136.

Adams, N.S., Walker, C.E, and Perry, R.W., 2011, A multi-year analysis of passage and survival at McNary Dam, 2004-09: U.S. Geological Survey Open-File Report 2011-1230, 128 p.

Akaike, H., 1973, Information theory and an extension of the maximum likelihood principle, in Petrov, B.N., and Csaki, F., eds., Second International Symposium on Information Theory: Budapest, Hungary, Akademiai Kiado, p. 267-281.

Burnham, K. P., D. R. Anderson, G. C. White, C. Brownie, and K. H. Pollock. 1987. Design and Analysis Methods for Fish Survival Experiments Based on Release-Recapture, American Fisheries Society Monograph 5, Bethesda, Maryland.

Burnham, K.P., and Anderson, D.R., 1998, Model selection and inference-A practical information theoretic approach: New York, Springer-Verlag, 353 p.

Collett, D., 2003, Modeling Binary Data: Boca Raton, Florida, Chapman and Hall/CRC, p. 387.

Collis, K., Roby, D.D., Craig, D.P., Ryan, B.A., and Ledgerwood, R.D., 2001, Colonial waterbird predation on juvenile salmonids tagged with passive integrated transponders in the Columbia River estuary-Vulnerability of different salmonid species, stocks, and rearing types: Transactions of the American Fisheries Society, v. 130, p. 385-396.

Cormack, R.M., 1964, Estimates of survival from the sighting of marked animals: Biometrika, v. 51, p. 429-438.

Jolly, G.M., 1965, Explicit estimates from capture-recapture data with both death and immigrationstochastic model: Biometrika, v. 52, p. 225-247.

Lebreton, J.D., Burnham, K.P., Clobert, J., and Anderson, D.R., 1992, Modeling survival and testing biological hypotheses using marked animals-A unified approach with case studies: Ecological Monographs, v. 62, p. 67-118.

Perry, R.W., Braatz, A.C., Fielding, S.D., Lucchesi, J.N., Plumb, J.M., Adams, N.S., and Rondorf, D.W., 2006, Survival and migration behavior of juvenile salmonids at McNary Dam, 2004: Final Report by the U.S. Geological Survey to the U.S. Army Corps of Engineers, Walla Walla District, Washington, Contract W68SBV40271050. 
Perry, R.W., Braatz, A.C., Novick, M.S., Lucchesi, J.L., Rutz, G.L., Koch, R.C., Schei, J.S., Adams, N.S., and Rondorf, D.W., 2007, Survival and migration behavior of juvenile salmonids at McNary Dam, 2005, Final Report by the U.S. Geological Survey to the U.S. Army Corps of Engineers, Walla Walla District, Contract W68SBV50407617, Walla Walla, Washington.

Mesa, M.G., 1994, Effects of multiple acute stressors on the predator avoidance ability and physiology of juvenile Chinook salmon: Transactions of the American Fisheries Society, v. 123, p. 786-793.

Plumb, J.M., Perry, R.W., Adams, N.S., and Rondorf, D.W., 2006, The effects of river impoundment and hatchery rearing on the migration behavior of juvenile steelhead in the Lower Snake River, Washington: North American Journal of Fisheries Management, v. 26, p. 438-452.

Raymond, H.L., 1968, Migration rates of hatchery Chinook salmon in relation to flows and impoundments in the Columbia and Snake rivers: Transactions of the American Fisheries Society, v. 97, p. 356-359.

Raymond, H.L., 1979, Effects of dams and impoundments on migrations of juvenile Chinook salmon and steelhead from the Snake River, 1966 to 1975: Transactions of the American Fisheries Society, v. 108, p. 505-529.

SAS Institute, Inc., 2008, SAS software, Version 9.2 of the SAS system for Windows: Cary, N.C.SAS Institute, Inc.

Seber, G.A.F., 1965, A note on the multiple recapture census: Biometrika, v. 52, p. 249-259.

Skalski, J.R., Smith, S.G., Iwamoto, R.N., Williams, J.G., and Hoffmann, A., 1998, Use of passive integrated transponder tags to estimate survival of migrant juvenile salmonids in the Snake and Columbia Rivers: Canadian Journal of Fisheries and Aquatic Sciences, v. 55, p. 1,484-1,493.

Steig, T.W., Nealson, P.A., Kumagai, K.K., Rowdon, B.J., Klein, L.S., and McFadden, B.D., 2007, Route-specific passage of juvenile steelhead and sockeye salmon using acoustic tag methodologies at Rocky Reach and Rock Island Dams in 2006: Final report by Hydroacoustic Technology, Inc., for Chelan County Public Utility District No. 1.

Steig, T.W., Nealson, P.A., Kumagai, K.K., Rowdon, B.J., Klein, L.S., and McFadden, B.D., 2008, Route-specific passage of juvenile Chinook and sockeye salmon using acoustic tag methodologies at Rocky Reach and Rock Island Dams in 2007: Final report by Hydroacoustic Technology, Inc., for Chelan County Public Utility District No. 1.

Steig, T.W., Nealson, P.A., Kumagai, K.K., Rowdon, B.J., Selleck, J.R., and McFadden, B.D., 2009, Route specific passage of juvenile Chinook, sockeye and juvenile steelhead salmon using acoustic tag methodologies at Rocky Reach and Rock Island Dams in 2008: Final report by Hydroacoustic Technology, Inc., for Chelan County Public Utility District No. 1.

Steig, T.W., Nealson, P.A., Kumagai, K.K., Rowdon, B.J., Selleck, J.R., and Tunnicliffe, C., 2010, Route specific passage of juvenile Chinook, sockeye and juvenile steelhead salmon using acoustic tag methodologies at Rocky Reach and Rock Island Dams in 2009: Final report by Hydroacoustic Technology, Inc., for Chelan County Public Utility District No. 1.

Sullivan, L.S., Wright, C.D., Rizor, S.E., Timko, M.A., Fitzgerald, C.A., Meagher, M.L., Skalski, J.R., and Townsend, R.L., 2009, Analysis of juvenile Chinook, steelhead and sockeye salmon behavior using acoustic tags at Wanapum and Priest Rapids dams, 2008: Final report by Hydroacoustic Technology, Inc., for Grant County Public Utility District No. 2.

Timko, M.A., Brown, L.S., Wright, C.D., O’Connor, R.R., Fitzgerald, C.A., Meager, M.L., Rizor, S.E., Nealson, P.A., and Johnston, S.V., 2007, Analysis of juvenile Chinook, steelhead, and sockeye salmon behavior using acoustic tags at Wanapum and Priest Rapids Dams, 2006: Final report by Hydroacoustic Technology, Inc., for Grant County Public Utility District No. 2. 
Timko, M.A., Brown, L.S., Wright, C.D., Rizor, S.E., Fitzgerald, C.A., O’Connor, R.R., and Meager, M.L., 2008, Analysis of juvenile Chinook, steelhead and sockeye salmon behavior using acoustic tags at Wanapum and Priest Rapids dams, 2007: Draft report by Hydroacoustic Technology, Inc., for Grant County Public Utility District No. 2.

Timko, M.A., Sullivan, L.S., Wright, C.D., Rizor, S.E., O’Connor, R.R., Skalski, J.R., Townsend, R.L., Fitzgerald, C.A., Meagher, M.M., Kukes, T.J., and Stephenson, J.D., 2010, Behavior and survival analysis of juvenile steelhead and sockeye through the Priest Rapids Hydroelectric Project in 2009: Final report by Blue Leaf Environmental for Grant County Public Utility District No. 2..

Vigg, S., Poe, T.P., Prendergast, L.A., and Hansel, H.C., 1991, Rates of consumption of juvenile salmonids and alternative prey fish by northern squawfish, walleyes, smallmouth bass, and channel catfish in John Day Reservoir, Columbia River: Transactions of the American Fisheries Society, v. 120, p. 421-438.

White, G.C., and Burnham, K.P., 1999, Program MARK: Colorado State University, accessed May 17, 2012 at http://warnercnr.colostate.edu/ gwhite/mark/mark.htm.

Whitney, R.R., Calvin, L.D., Erho, Jr., M.W., and Coutant, C.C., 1997, Downstream passage for salmon at hydroelectric projects in the Columbia River Basin-Development, installation, and evaluation: Portland, Oreg., Northwest Power Planning Council, Report No. 97-15. 


\section{Appendix A: All Candidate Models Examined for Spillway Survival}

Table A1. Model selection for fish that passed through the spillway at McNary Dam relating survival $(\varnothing)$ as a function of individual and group covariates using the fixed structure of the best model for $p$ and $\lambda$ parameters for yearling Chinook salmon, 2004-09.

[The best-fit models are indicated in bold. Q, discharge]

\begin{tabular}{|c|c|c|c|c|}
\hline Model & $\begin{array}{l}\text { Number of } \\
\text { parameters }\end{array}$ & $\mathrm{AIC} c$ & $\Delta \mathrm{AlC}_{c}$ & Deviance \\
\hline Tag burden + Spill bay Q + Bay type + Temperature + Spill bay Q*Bay type & 18 & 8,199.62 & 0.00 & $8,163.53$ \\
\hline Tag burden + Spill bay Q + Bay type + Temperature & 17 & 8,201.00 & 1.38 & 8,166.92 \\
\hline Tag burden + Spill bay Q + Bay type & 16 & $8,201.81$ & 2.18 & $8,169.73$ \\
\hline Tag burden + Total Q + Temperature & 16 & $8,202.53$ & 2.90 & $8,170.46$ \\
\hline Tag burden + Spill bay Q + Temperature & 16 & $8,202.70$ & 3.08 & $8,170.63$ \\
\hline Tag burden + Spill bay Q + Bay type + Temperature + Spill bay Q*Bay type + Year & 23 & $8,203.17$ & 3.54 & $8,157.02$ \\
\hline Tag burden + Total Q + Temperature + Passage location & 18 & 8,203.22 & 3.60 & $8,167.13$ \\
\hline Tag burden + Temperature & 15 & $8,203.45$ & 3.82 & $8,173.38$ \\
\hline Tag burden + Total Q & 15 & $8,203.86$ & 4.24 & $8,173.80$ \\
\hline Tag burden + Total Q + Passage location & 17 & 8,203.99 & 4.37 & $8,169.91$ \\
\hline Tag burden + Spill bay Q + Bay type + Temperature + Year & 22 & $8,204.20$ & 4.58 & $8,160.07$ \\
\hline Tag burden + Temperature + Passage location & 17 & $8,204.42$ & 4.80 & $8,170.34$ \\
\hline Tag burden + Total Q + Spill pattern & 19 & $8,205.03$ & 5.40 & $8,166.93$ \\
\hline Tag burden + Spill Q & 15 & $8,206.33$ & 6.71 & $8,176.27$ \\
\hline Tag burden + Spill Q + Passage location & 17 & $8,206.71$ & 7.09 & $8,172.63$ \\
\hline Tag burden + Total Q + Temperature + Year & 21 & $8,206.87$ & 7.24 & $8,164.74$ \\
\hline Tag burden + Spill pattern + Temperature & 19 & $8,207.03$ & 7.41 & 8,168.93 \\
\hline Tag burden + Spill pattern & 18 & 8,207.95 & 8.32 & 8,171.86 \\
\hline
\end{tabular}


Table A1. Model selection for fish that passed through the spillway at McNary Dam relating survival ( $\varnothing)$ as a function of individual and group covariates using the fixed structure of the best model for $p$ and $\lambda$ parameters for yearling Chinook salmon, 2004-09. - Continued

[Q, discharge]

\begin{tabular}{|c|c|c|c|c|}
\hline Model & $\begin{array}{c}\text { Number of } \\
\text { parameters }\end{array}$ & AIC $c$ & $\Delta \mathrm{AlC}_{c}$ & Deviance \\
\hline Tag burden + Spill bay Q & 15 & $8,208.43$ & 8.81 & $8,178.37$ \\
\hline Tag burden + Spill bay Q + Passage location & 17 & $8,209.43$ & 9.81 & $8,175.35$ \\
\hline Spill pattern + Fish weight & 18 & $8,209.85$ & 10.23 & $8,173.76$ \\
\hline Tag burden + Bay type & 15 & $8,211.71$ & 12.09 & $8,181.65$ \\
\hline Tag burden & 14 & $8,212.33$ & 12.71 & $8,184.28$ \\
\hline Tag burden + Passage location & 16 & $8,212.50$ & 12.88 & $8,180.43$ \\
\hline Temperature & 14 & $8,214.55$ & 14.93 & $8,186.50$ \\
\hline Spill bay Q + Bay type & 15 & $8,215.15$ & 15.52 & $8,185.09$ \\
\hline Passage location + Temperature & 16 & $8,215.37$ & 15.74 & $8,183.30$ \\
\hline Bay type + Fish weight & 15 & $8,215.97$ & 16.35 & $8,185.91$ \\
\hline Spill pattern & 17 & $8,216.99$ & 17.36 & $8,182.91$ \\
\hline Fish weight & 14 & $8,217.27$ & 17.64 & $8,189.21$ \\
\hline Total Q & 14 & $8,218.38$ & 18.75 & $8,190.32$ \\
\hline Total Q + Passage location & 16 & $8,218.60$ & 18.98 & $8,186.53$ \\
\hline Spill bay Q & 14 & $8,218.90$ & 19.27 & $8,190.84$ \\
\hline Spill Q & 14 & $8,219.86$ & 20.24 & $8,191.81$ \\
\hline Spill Q + Passage location & 16 & $8,220.08$ & 20.46 & $8,188.01$ \\
\hline Spill bay Q + Passage location & 16 & $8,220.38$ & 20.76 & $8,188.31$ \\
\hline Intercept only & 13 & $8,220.45$ & 20.83 & $8,194.41$ \\
\hline Bay type & 14 & $8,220.58$ & 20.95 & $8,192.52$ \\
\hline Passage location & 15 & $8,220.89$ & 21.26 & $8,190.82$ \\
\hline
\end{tabular}


Table A2. Model selection for fish that passed through the spillway at McNary Dam relating survival $(\varnothing)$ as a function of individual and group covariates using the fixed structure of the best model for $p$ and $\lambda$ parameters for juvenile steelhead, 2004-09.

[The best-fit models are indicated in bold]

\begin{tabular}{|c|c|c|c|c|}
\hline Model & $\begin{array}{l}\text { Number of } \\
\text { parameters }\end{array}$ & $\mathrm{AIC}_{\mathrm{C}}$ & $\Delta \mathrm{AlC}_{\mathrm{C}}$ & Deviance \\
\hline Temperature + Spill discharge + Fish weight $^{1}$ & 17 & $6,464.37$ & 0.00 & $6,430.27$ \\
\hline Temperature + Total discharge + Spill pattern + Fish weight $^{2}$ & 21 & $6,466.18$ & 1.81 & $6,424.04$ \\
\hline Temperature + Total discharge + Percent spill + Fish weight ${ }^{3}$ & 18 & $6,466.72$ & 2.35 & $6,430.61$ \\
\hline Temperature + Total discharge + Spill pattern + Total discharge*Spill pattern + Fish weight ${ }^{4}$ & 25 & $6,467.26$ & 2.89 & $6,417.05$ \\
\hline Temperature + Total discharge + Fish weight $^{5}$ & 17 & $6,468.82$ & 4.45 & $6,434.73$ \\
\hline Temperature + Spill bay discharge + Spill pattern + Fish weight & 21 & $6,471.93$ & 7.56 & $6,429.79$ \\
\hline Temperature + Spill pattern + Fish weight & 20 & $6,473.18$ & 8.81 & $6,433.05$ \\
\hline Temperature + Spill discharge & 16 & $6,473.82$ & 9.45 & $6,441.73$ \\
\hline Temperature + Spill bay discharge + Bay type + Fish weight & 18 & $6,475.74$ & 11.37 & $6,439.63$ \\
\hline Temperature + Spill bay discharge + Fish weight & 17 & $6,476.29$ & 11.92 & $6,442.19$ \\
\hline Temperature + Fish weight & 16 & $6,477.54$ & 13.17 & $6,445.45$ \\
\hline Temperature + Total discharge & 16 & $6,479.48$ & 15.11 & $6,447.40$ \\
\hline Temperature + Spill pattern & 19 & $6,480.42$ & 16.05 & $6,442.30$ \\
\hline Temperature + Tag burden & 16 & $6,481.75$ & 17.38 & $6,449.66$ \\
\hline Temperature + Percent spill & 16 & $6,482.71$ & 18.34 & $6,450.63$ \\
\hline Temperature + Spill bay discharge & 16 & $6,483.19$ & 18.82 & $6,451.10$ \\
\hline Temperature & 15 & $6,484.47$ & 20.10 & $6,454.39$ \\
\hline
\end{tabular}


Table A2. Model selection for fish that passed through the spillway at McNary Dam relating survival (ø) as a function of individual and group covariates using the fixed structure of the best model for $p$ and $\lambda$ parameters for juvenile steelhead, 2004-09.-Continued

\begin{tabular}{lcrrrr}
\hline & Model & $\begin{array}{c}\text { Number of } \\
\text { parameters }\end{array}$ & AIC $c$ & AAIC $c$ & Deviance \\
\hline Fish weight & 15 & $6,490.43$ & 26.06 & $6,460.36$ \\
Tag burden & 15 & $6,492.39$ & 28.02 & $6,462.31$ \\
Spill pattern + Fish weight & 19 & $6,494.81$ & 30.44 & $6,456.69$ \\
Spill pattern + Tag burden & 19 & $6,495.65$ & 31.28 & $6,457.53$ \\
Intercept only & 14 & $6,496.47$ & 32.10 & $6,468.40$ \\
Spill pattern & 18 & $6,500.63$ & 36.26 & $6,464.52$ \\
\hline
\end{tabular}

${ }^{1}$ Addition of year to this model decreased AIC $\mathrm{C}_{\mathrm{c}}$ by 5.45 .

${ }^{2}$ Addition of year to this model decreased AIC $_{c}$ by 6.88 .

${ }^{3}$ Addition of year to this model decreased $\mathrm{AIC}_{\mathrm{c}}$ by 7.62 .

${ }^{4}$ Addition of year to this model decreased AIC $_{\mathrm{c}}$ by 5.64 .

${ }^{5}$ Addition of year to this model decreased AIC $_{c}$ by 4.40 . 
Table A3. Model selection for fish that passed through the spillway at McNary Dam relating survival (ø) as a function of individual and group covariates using the fixed structure of the best model for $p$ and $\lambda$ parameters for subyearling Chinook salmon, 2004-09.

[The best-fit models are indicated in bold. Temp, temperature; Q, discharge; Passloc, Passage location]

\begin{tabular}{|c|c|c|c|c|}
\hline Model & $\begin{array}{l}\text { Number of } \\
\text { parameters }\end{array}$ & $\mathrm{AIC} c$ & $\Delta \mathrm{AIC}_{\mathrm{C}}$ & Deviance \\
\hline Spill pattern + Tag burden + Temp + Spill bay $Q+$ Spill $Q+$ Percent spill & 20 & $8,406.22$ & 0.00 & 8,366.10 \\
\hline Spill pattern + Tag burden + Temp + Spill bay $Q+$ Total $Q$ & 19 & $8,406.55$ & 0.33 & 8,368.45 \\
\hline Spill pattern + Tag burden + Temp + Spill bay Q + Spill Q + Percent spill + Passloc & 22 & 8,406.59 & 0.37 & 8,362.45 \\
\hline Spill pattern + Tag burden + Temp + Bay type + Total $Q$ & 19 & $8,406.90$ & 0.68 & $8,368.80$ \\
\hline Spill pattern + Fish weight + Temp + Spill bay Q + Total Q & 19 & $8,407.74$ & 1.52 & 8,369.64 \\
\hline Spill pattern + Tag burden + Temp + Spill bay Q + Total Q + Spill pattern*Total $Q$ & 23 & $8,408.18$ & 1.97 & $8,362.03$ \\
\hline Spill pattern + Tag burden + Temp + Total Q & 18 & $8,408.57$ & 2.35 & $8,372.47$ \\
\hline Spill pattern + Tag burden + Temp + Bay type + Total Q + Total Q*Spill pattern & 23 & $8,408.65$ & 2.44 & $8,362.50$ \\
\hline Tag burden + Temp + Bay type + Total Q & 15 & $8,410.22$ & 4.00 & $8,380.15$ \\
\hline Spill pattern + Temp + Spill bay Q + Total Q & 18 & $8,410.46$ & 4.25 & $8,374.37$ \\
\hline Spill pattern +Temp + Spill bay Q + Total Q + Passloc & 20 & $8,410.51$ & 4.29 & $8,370.39$ \\
\hline Spill pattern + Temp + Bay type + Total Q & 18 & $8,410.64$ & 4.42 & $8,374.54$ \\
\hline Spill pattern + Temp + Spill bay Q + Spill Q + Percent spill & 19 & $8,410.67$ & 4.45 & $8,372.56$ \\
\hline Spill pattern + Tag burden + Temp + Spill bay Q + Total Q + Spill pattern*Spill bay Q & 23 & $8,411.15$ & 4.93 & $8,365.00$ \\
\hline Percent spill + Tag burden + Temp + Spill bay Q + Spill Q & 16 & $8,411.27$ & 5.05 & 8,379.19 \\
\hline Spill pattern + Temp + Bay type + Total Q + Passloc & 20 & $8,411.31$ & 5.10 & $8,371.20$ \\
\hline Percent spill + Tag burden + Temp + Spill bay Q + Spill Q + Passloc & 18 & $8,411.64$ & 5.42 & 8,375.54 \\
\hline Tag burden + Temp + Spill bay Q + Total Q + Passloc + Passloc*Spill bay Q & 19 & $8,411.67$ & 5.45 & $8,373.56$ \\
\hline Tag burden + Temp + Spill bay Q + Total Q & 15 & $8,411.74$ & 5.53 & $8,381.68$ \\
\hline Tag burden + Temp + Spill bay Q + Total Q + Passloc & 17 & $8,412.35$ & 6.13 & $8,378.27$ \\
\hline Spill pattern + Temp + Total Q & 17 & $8,412.42$ & 6.21 & $8,378.34$ \\
\hline Percent spill + Tag burden + Temp + Spill bay Q + Spill Q + Passloc + Passloc*Spill bay Q & 20 & $8,412.64$ & 6.43 & $8,372.53$ \\
\hline
\end{tabular}


Table A3. Model selection for fish that passed through the spillway at McNary Dam relating survival (ø) as a function of individual and group covariates using the fixed structure of the best model for $p$ and $\lambda$ parameters for subyearling Chinook salmon, 2004-09.-Continued

[Temp, temperature; Q, discharge; Passloc, Passage location]

\begin{tabular}{|c|c|c|c|c|}
\hline Model & $\begin{array}{l}\text { Number of } \\
\text { parameters }\end{array}$ & $\mathrm{AIC}_{c}$ & $\Delta \mathrm{AIC} c$ & Deviance \\
\hline Temp + Bay type + Total Q & 14 & $8,414.26$ & 8.04 & $8,386.20$ \\
\hline Temp + Spill bay Q + Spill Q + Percent spill & 15 & $8,415.37$ & 9.15 & $8,385.30$ \\
\hline Temp + Bay type + Total Q + Passloc & 16 & $8,415.58$ & 9.36 & $8,383.50$ \\
\hline Temp + Spill bay Q + Total Q + Passloc + Passloc*Spill bay Q & 18 & $8,415.63$ & 9.41 & $8,379.53$ \\
\hline Temp + Spill bay Q + Spill Q + Percent spill + Passloc & 17 & $8,415.65$ & 9.43 & $8,381.56$ \\
\hline Temp + Spill bay Q + Total Q & 14 & $8,416.54$ & 10.32 & $8,388.48$ \\
\hline Temp + Spill bay Q + Total Q + Passloc & 16 & $8,417.06$ & 10.84 & $8,384.98$ \\
\hline Total Q + Temp + Tag burden & 14 & $8,417.66$ & 11.44 & $8,389.60$ \\
\hline Spill pattern + Tag burden + Temp & 17 & $8,420.34$ & 14.12 & $8,386.25$ \\
\hline Tag burden + Temp + Spill bay Q + Spill Q + Passloc + Passloc*Spill bay Q & 19 & $8,421.54$ & 15.33 & $8,383.44$ \\
\hline Spill pattern + Temp + Percent spill & 17 & $8,421.60$ & 15.38 & $8,387.51$ \\
\hline Spill pattern + Temp + Spill bay Q + Spill Q & 18 & $8,421.96$ & 15.74 & $8,385.87$ \\
\hline Temp + Spill Q + Percent spill & 14 & $8,422.11$ & 15.89 & 8,394.05 \\
\hline Temp + Spill Q + Total Q & 14 & $8,422.17$ & 15.96 & $8,394.11$ \\
\hline Temp + Total Q & 13 & $8,422.35$ & 16.13 & $8,396.30$ \\
\hline Spill pattern + Temp + Spill bay Q & 17 & $8,423.03$ & 16.81 & $8,388.94$ \\
\hline Temp + Total Q + Passloc & 15 & $8,423.56$ & 17.34 & $8,393.49$ \\
\hline Spill pattern + Temp & 16 & $8,423.82$ & 17.60 & $8,391.75$ \\
\hline Bay type + Temp + Spill Q & 14 & $8,423.93$ & 17.71 & $8,395.87$ \\
\hline Spill pattern + Spill bay Q + Total Q & 17 & $8,424.25$ & 18.03 & $8,390.16$ \\
\hline Temp + Spill bay Q + Spill Q + Passloc & 16 & $8,424.29$ & 18.07 & $8,392.22$ \\
\hline Temp + Spill bay Q + Spill Q & 14 & $8,424.32$ & 18.10 & 8,396.26 \\
\hline
\end{tabular}


Table A3. Model selection for fish that passed through the spillway at McNary Dam relating survival $(\varnothing)$ as a function of individual and group covariates using the fixed structure of the best model for $p$ and $\lambda$ parameters for subyearling Chinook salmon, 2004-09.-Continued

[Temp, temperature; Q, discharge; Passloc, Passage location]

\begin{tabular}{|c|c|c|c|c|}
\hline Model & $\begin{array}{l}\text { Number of } \\
\text { parameters }\end{array}$ & $\mathrm{AIC}_{\mathrm{c}}$ & $\Delta \mathrm{AlC} c$ & Deviance \\
\hline Spill pattern + Total Q & 16 & $8,426.60$ & 20.38 & $8,394.52$ \\
\hline Bay type + Total Q & 13 & $8,428.61$ & 22.40 & $8,402.56$ \\
\hline Spill bay Q + Spill Q + Percent spill + Passloc & 16 & $8,429.64$ & 23.42 & $8,397.56$ \\
\hline Tag burden + Spill bay Q + Total Q & 14 & $8,429.80$ & 23.59 & $8,401.74$ \\
\hline Spill bay Q + Spill Q + Percent spill & 14 & $8,430.01$ & 23.79 & $8,401.95$ \\
\hline Spill bay Q + Total Q & 13 & $8,430.09$ & 23.87 & $8,404.04$ \\
\hline Temp + Spill Q & 13 & $8,431.26$ & 25.04 & $8,405.21$ \\
\hline Temp + Spill Q + Passloc & 15 & $8,432.95$ & 26.74 & $8,402.89$ \\
\hline Spill pattern + Total Q + Spill pattern*Total Q & 18 & $8,432.99$ & 26.77 & $8,396.89$ \\
\hline Tag burden + Total Q & 13 & $8,435.97$ & 29.75 & $8,409.92$ \\
\hline Total Q & 12 & $8,436.17$ & 29.96 & $8,412.13$ \\
\hline Total Q + Passloc & 14 & $8,436.69$ & 30.47 & $8,408.63$ \\
\hline Spill Q + Percent spill & 13 & $8,437.43$ & 31.21 & $8,411.38$ \\
\hline Spill Q + Percent spill + Passloc & 15 & $8,438.13$ & 31.92 & $8,408.07$ \\
\hline Temp + Spill bay Q + Spill Q + Percent spill + Passloc + Passloc*Spill bay Q & 19 & $8,438.92$ & 32.70 & $8,400.81$ \\
\hline Temp + Bay type + Spill bay Q & 14 & $8,440.66$ & 34.45 & $8,412.61$ \\
\hline Temp + Bay type & 13 & $8,441.03$ & 34.82 & $8,414.98$ \\
\hline Tag burden + Temp + Spill bay Q & 14 & $8,446.16$ & 39.94 & $8,418.10$ \\
\hline Temp + Spill bay Q + Percent spill & 14 & $8,449.43$ & 43.21 & $8,421.37$ \\
\hline Temp + Spill bay Q + Percent spill + Passloc & 16 & $8,450.24$ & 44.03 & $8,418.17$ \\
\hline Temp + Spill bay Q & 13 & $8,450.76$ & 44.54 & $8,424.71$ \\
\hline Tag burden + Temp & 13 & $8,450.85$ & 44.64 & $8,424.80$ \\
\hline
\end{tabular}


Table A3. Model selection for fish that passed through the spillway at McNary Dam relating survival $(\varnothing)$ as a function of individual and group covariates using the fixed structure of the best model for $p$ and $\lambda$ parameters for subyearling Chinook salmon, 2004-09.-Continued

[Temp, temperature; Q, discharge; Passloc, Passage location]

\begin{tabular}{|c|c|c|c|c|}
\hline Model & $\begin{array}{c}\text { No. } \\
\text { parameters }\end{array}$ & $\mathrm{AIC}_{c}$ & $\Delta \mathrm{AlC}_{c}$ & Deviance \\
\hline Temp + Spill bay Q + Passloc & 15 & $8,451.26$ & 45.04 & $8,421.20$ \\
\hline Photoperiod + Temp + Percent spill & 14 & $8,452.83$ & 46.61 & $8,424.77$ \\
\hline Photoperiod + Temp & 13 & $8,453.80$ & 47.58 & $8,427.75$ \\
\hline Temp + Percent spill & 13 & $8,454.55$ & 48.33 & $8,428.50$ \\
\hline Temp & 12 & $8,455.36$ & 49.15 & $8,431.32$ \\
\hline Temp + Passloc & 14 & $8,455.49$ & 49.27 & $8,427.43$ \\
\hline Spill pattern + Spill bay Q + Spill Q & 17 & $8,456.18$ & 49.96 & $8,422.09$ \\
\hline Spill pattern + Percent spill & 16 & $8,456.58$ & 50.36 & $8,424.50$ \\
\hline Spill pattern + Spill Q + Spill pattern * Spill Q & 20 & $8,458.25$ & 52.04 & $8,418.14$ \\
\hline Spill bay Q + Spill Q + Passloc & 15 & $8,458.80$ & 52.59 & $8,428.74$ \\
\hline Spill pattern + Spill Q & 16 & $8,458.82$ & 52.60 & $8,426.75$ \\
\hline Bay type + Spill Q & 13 & $8,459.42$ & 53.21 & $8,433.37$ \\
\hline Spill bay Q + Spill Q & 13 & $8,459.75$ & 53.53 & $8,433.70$ \\
\hline Spill pattern + Percent spill + Spill pattern*Percent spill & 20 & $8,459.80$ & 53.58 & $8,419.68$ \\
\hline Photoperiod + Spill Q & 13 & $8,466.25$ & 60.03 & $8,440.20$ \\
\hline Spill Q & 12 & $8,467.98$ & 61.77 & $8,443.94$ \\
\hline Spill Q + Passloc & 14 & $8,468.87$ & 62.65 & $8,440.81$ \\
\hline Spill Q + Passloc + Passloc*Spill Q & 16 & $8,469.13$ & 62.92 & $8,437.06$ \\
\hline Spill pattern & 15 & $8,470.29$ & 64.07 & $8,440.22$ \\
\hline Bay type + Spill bay Q + Bay type*Spill bay Q & 14 & $8,495.62$ & 89.40 & $8,467.56$ \\
\hline Bay type + Spill bay Q & 13 & $8,504.48$ & 98.27 & $8,478.43$ \\
\hline Spill bay Q + Passloc + Passloc*Spill bay Q & 16 & $8,506.11$ & 99.89 & $8,474.03$ \\
\hline
\end{tabular}


Table A3. Model selection for fish that passed through the spillway at McNary Dam relating survival ( $\varnothing$ ) as a function of individual and group covariates using the fixed structure of the best model for $p$ and $\lambda$ parameters for subyearling Chinook salmon, 2004-09.—Continued

[Q, discharge; Passloc, Passage location]

\begin{tabular}{|c|c|c|c|c|}
\hline Model & $\begin{array}{c}\text { Number of } \\
\text { parameters }\end{array}$ & $\mathrm{AIC} c$ & $\Delta \mathrm{AIC} c$ & Deviance \\
\hline Year & 15 & $8,512.36$ & 106.14 & $8,482.29$ \\
\hline Bay type & 12 & $8,515.97$ & 109.75 & $8,491.93$ \\
\hline Photoperiod + Spill bay Q + Photoperiod*Spill bay Q & 14 & $8,519.69$ & 113.47 & $8,491.63$ \\
\hline Photoperiod + Spill bay Q & 13 & $8,529.93$ & 123.71 & $8,503.87$ \\
\hline Photoperiod & 12 & $8,530.45$ & 124.24 & $8,506.41$ \\
\hline Passloc & 13 & $8,534.75$ & 128.53 & $8,508.70$ \\
\hline Passloc + Percent spill & 14 & $8,536.71$ & 130.50 & $8,508.66$ \\
\hline Spill bay Q & 12 & $8,537.19$ & 130.98 & $8,513.15$ \\
\hline Passloc + Percent spill + Passloc*Percent spill & 16 & $8,537.77$ & 131.55 & $8,505.70$ \\
\hline Intercept & 11 & $8,538.06$ & 131.85 & $8,516.03$ \\
\hline
\end{tabular}


Table A4. Model selection for fish that passed through the spillway at McNary Dam relating survival (ø) as a function of individual and group covariates using the fixed structure of the best model for $p$ and $\lambda$ parameters for sockeye salmon, 2004-09.

[The best-fit models are indicated in bold]

\begin{tabular}{|c|c|c|c|c|}
\hline Model & $\begin{array}{l}\text { Number of } \\
\text { parameters }\end{array}$ & $\mathrm{AIC} c$ & $\Delta \mathrm{AlC} c$ & Deviance \\
\hline Passage location + Spill discharge + Temperature + Tag burden & 13 & $5,171.48$ & 0.00 & $5,145.40$ \\
\hline Passage location + Total discharge + Temperature + Percent spill + Tag burden & 14 & $5,173.31$ & 1.83 & $5,145.22$ \\
\hline Passage location + Total discharge + Temperature + Tag burden & 13 & $5,174.16$ & 2.68 & $5,148.08$ \\
\hline Passage location + Percent spill + Temperature + Tag burden & 14 & $5,175.61$ & 4.13 & $5,147.52$ \\
\hline Passage location + Spill discharge + Tag burden & 12 & $5,178.99$ & 7.51 & $5,154.92$ \\
\hline Spill discharge + Temperature + Tag burden & 11 & $5,179.32$ & 7.84 & $5,157.26$ \\
\hline Total discharge + Temperature + Percent spill + Tag burden & 12 & $5,181.19$ & 9.71 & $5,157.12$ \\
\hline Passage location + Total discharge + Percent spill + Tag burden & 13 & $5,181.59$ & 10.11 & $5,155.51$ \\
\hline Percent spill + Temperature + Tag burden & 11 & $5,181.61$ & 10.13 & $5,159.55$ \\
\hline Total discharge + Temperature + Tag burden & 11 & $5,, 181.85$ & 10.37 & $5,159.79$ \\
\hline Passage location + Percent spill + Tag burden & 12 & $5,182.51$ & 11.03 & $5,158.44$ \\
\hline Passage location + Total discharge + Tag burden & 12 & $5,183.01$ & 11.53 & $5,158.94$ \\
\hline Passage location + Temperature + Spill bay discharge + Tag burden & 13 & $5,184.03$ & 12.56 & $5,157.95$ \\
\hline Spill discharge + Tag burden & 10 & $5,185.95$ & 14.48 & $5,165.91$ \\
\hline Total discharge + Percent spill + Tag burden & 11 & $5,188.68$ & 17.20 & $5,166.62$ \\
\hline Percent spill + Tag burden & 10 & $5,189.62$ & 18.14 & $5,169.57$ \\
\hline Total discharge + Tag burden & 10 & $5,189.70$ & 18.22 & $5,169.65$ \\
\hline Spill pattern + Passage location + Temperature + Tag burden & 14 & $5,191.75$ & 20.28 & $5,163.66$ \\
\hline
\end{tabular}


Table A4. Model selection for fish that passed through the spillway at McNary Dam relating survival (ø) as a function of individual and group covariates using the fixed structure of the best model for $p$ and $\lambda$ parameters for sockeye salmon, 2004-09.-Continued

\begin{tabular}{|c|c|c|c|c|}
\hline Model & $\begin{array}{l}\text { Number of } \\
\text { parameters }\end{array}$ & $\mathrm{AIC} c$ & $\Delta \mathrm{AIC} c$ & Deviance \\
\hline Passage location + Spill bay discharge + Tag burden & 12 & $5,193.14$ & 21.66 & $5,169.07$ \\
\hline Spill pattern + Passage location + Spill bay discharge + Tag burden & 14 & $5,194.81$ & 23.33 & $5,166.72$ \\
\hline Spill pattern ++ Spill bay discharge + Tag burden & 13 & $5,195.62$ & 24.14 & $5,169.54$ \\
\hline Passage location + Spill discharge + Temperature & 12 & $5,196.39$ & 24.91 & $5,172.32$ \\
\hline Passage location + Total discharge + Temperature & 12 & $5,199.21$ & 27.73 & $5,175.14$ \\
\hline Bay type + Temperature + Spill bay discharge + Tag burden & 12 & $5,201.12$ & 29.64 & $5,177.05$ \\
\hline Spill pattern + Temperature + Tag burden & 12 & $5,201.23$ & 29.75 & $5,177.16$ \\
\hline Temperature + Spill bay discharge + Tag burden & 11 & $5,201.78$ & 30.30 & $5,179.72$ \\
\hline Passage location + Temperature + Tag burden & 12 & $5,202.73$ & 31.26 & $5,178.67$ \\
\hline Passage location + Percent spill + Temperature & 12 & $5,204.49$ & 33.01 & $5,180.42$ \\
\hline Spill discharge + Fish weight & 10 & $5,206.26$ & 34.78 & $5,186.21$ \\
\hline Passage location + Spill discharge & 11 & $5,206.26$ & 34.78 & $5,184.20$ \\
\hline Spill discharge + Temperature & 10 & $5,207.53$ & 36.05 & $5,187.48$ \\
\hline Passage location + Total discharge + Percent spill & 12 & $5,207.76$ & 36.28 & $5,183.69$ \\
\hline Spill pattern + Spill discharge + Temperature & 12 & $5,208.94$ & 37.46 & $5,184.87$ \\
\hline Total discharge + Temperature & 10 & $5,209.46$ & 37.99 & $5,189.42$ \\
\hline Total discharge + Fish weight & 10 & $5,209.64$ & 38.16 & $5,189.59$ \\
\hline Spill pattern + Spill bay discharge + Tag burden & 12 & $5,210.97$ & 39.50 & $5,186.91$ \\
\hline
\end{tabular}


Table A4. Model selection for fish that passed through the spillway at McNary Dam relating survival ( $\varnothing)$ as a function of individual and group covariates using the fixed structure of the best model for $p$ and $\lambda$ parameters for sockeye salmon, 2004-09. - Continued

\begin{tabular}{|c|c|c|c|c|}
\hline Model & $\begin{array}{l}\text { Number of } \\
\text { parameters }\end{array}$ & $\mathrm{AIC} c$ & $\Delta \mathrm{AIC} C$ & Deviance \\
\hline Passage location + Total discharge & 11 & $5,211.67$ & 40.19 & $5,189.61$ \\
\hline Spill bay discharge + Tag burden & 10 & $5,212.26$ & 40.78 & $5,192.21$ \\
\hline Temperature + Tag burden & 10 & $5,213.08$ & 41.61 & $5,193.04$ \\
\hline Spill pattern + Passage location + Tag burden & 13 & $5,213.84$ & 42.36 & $5,187.76$ \\
\hline Spill pattern + Passage location + Total discharge & 13 & $5,215.50$ & 44.02 & $5,189.42$ \\
\hline Spill pattern + Passage location + Spill bay discharge + Temperature & 13 & $5,216.44$ & 44.97 & $5,190.36$ \\
\hline Spill discharge + Spill bay discharge & 10 & $5,216.70$ & 45.22 & $5,196.65$ \\
\hline Passage location + Percent spill & 11 & $5,216.78$ & 45.30 & $5,194.72$ \\
\hline Percent spill + Temperature & 10 & $5,216.83$ & 45.35 & $5,196.78$ \\
\hline Spill discharge & 9 & $5,217.61$ & 46.13 & $5,199.57$ \\
\hline Passage location + Tag burden & 11 & $5,218.02$ & 46.55 & $5,195.97$ \\
\hline Total discharge + Percent spill & 10 & $5,219.02$ & 47.54 & $5,198.97$ \\
\hline Spill pattern + Tag burden & 11 & $5,221.93$ & 50.45 & $5,199.87$ \\
\hline Total discharge & 9 & $5,222.02$ & 50.55 & $5,203.99$ \\
\hline Tag burden & 9 & $5,227.31$ & 55.84 & $5,209.27$ \\
\hline Percent spill & 9 & $5,229.32$ & 57.84 & $5,211.28$ \\
\hline Spill pattern + Passage location + Temperature & 13 & $5,240.28$ & 68.80 & $5,214.20$ \\
\hline Spill pattern + Passage location + Spill bay discharge & 13 & $5,244.10$ & 72.62 & $5,218.02$ \\
\hline
\end{tabular}


Table A4. Model selection for fish that passed through the spillway at McNary Dam relating survival ( $\varnothing)$ as a function of individual and group covariates using the fixed structure of the best model for $p$ and $\lambda$ parameters for sockeye salmon, 2004-09. - Continued

\begin{tabular}{|c|c|c|c|c|}
\hline Model & $\begin{array}{l}\text { Number of } \\
\text { parameters }\end{array}$ & $\mathrm{AIC} c$ & $\Delta \mathrm{AIC} c$ & Deviance \\
\hline Passage location + Spill bay discharge & 11 & $5,245.67$ & 74.19 & $5,223.61$ \\
\hline Spill pattern + Temperature & 11 & $5,253.62$ & 82.14 & $5,231.56$ \\
\hline Bay type + Temperature + Spill bay discharge & 11 & $5,258.57$ & 87.09 & $5,236.51$ \\
\hline Temperature + Spill bay discharge & 10 & $5,261.55$ & 90.08 & $5,241.51$ \\
\hline Passage location + Temperature & 11 & $5,268.44$ & 96.96 & $5,246.38$ \\
\hline Spill pattern + Bay type + Spill bay discharge & 12 & $5,278.35$ & 106.87 & $5,254.28$ \\
\hline Fish weight & 9 & $5,278.43$ & 106.95 & $5,260.39$ \\
\hline Spill pattern + Spill bay discharge & 11 & $5,280.20$ & 108.73 & $5,258.15$ \\
\hline Bay type + Spill bay discharge & 10 & $5,284.39$ & 112.91 & $5,264.34$ \\
\hline Bay type + Temperature & 10 & $5,288.46$ & 116.98 & $5,268.41$ \\
\hline Temperature & 9 & $5,288.62$ & 117.14 & $5,270.58$ \\
\hline Spill bay discharge & 9 & $5,289.73$ & 118.25 & $5,271.69$ \\
\hline Spill pattern + Passage location & 12 & $5,292.11$ & 120.63 & $5,268.04$ \\
\hline Passage location & 10 & $5,306.96$ & 135.48 & $5,286.91$ \\
\hline Spill pattern & 10 & $5,310.94$ & 139.46 & $5,290.89$ \\
\hline Bay type & 9 & $5,328.93$ & 157.46 & $5,310.89$ \\
\hline Intercept & 8 & $5,329.44$ & 157.96 & $5,313.41$ \\
\hline
\end{tabular}




\section{Appendix B: All Candidate Models Examined for Bypass Survival}

Table B1. Model selection for fish that passed through the juvenile bypass system outfall at McNary Dam relating survival ( $\varnothing)$ as a function of individual and group covariates using the fixed structure of the best model for $p$ and $\lambda$ parameters for yearling Chinook salmon, $2004-09$.

[The best-fit models are indicated in bold]

\begin{tabular}{|c|c|c|c|c|}
\hline Model & $\begin{array}{l}\text { Number of } \\
\text { parameters }\end{array}$ & $\mathrm{AIC}_{c}$ & $\Delta \mathrm{AIC}_{c}$ & Deviance \\
\hline Photoperiod & 14 & $5,553.48$ & 0.00 & $5,525.39$ \\
\hline Intercept & 13 & $5,554.60$ & 1.12 & $5,528.52$ \\
\hline Photoperiod + Spill pattern & 19 & $5,558.99$ & 5.51 & $5,520.84$ \\
\hline Spill pattern & 18 & $5,559.69$ & 6.21 & $5,523.55$ \\
\hline
\end{tabular}


Table B2. Model selection for fish that passed through the juvenile bypass system outfall at McNary Dam relating survival (ø) as a function of individual and group covariates using the fixed structure of the best model for $p$ and $\lambda$ parameters for juvenile steelhead, 2004-09.

[The best-fit models are indicated in bold]

\begin{tabular}{|c|c|c|c|c|}
\hline Model & $\begin{array}{l}\text { Number of } \\
\text { parameters }\end{array}$ & $\mathrm{AIC}_{c}$ & $\Delta \mathrm{AlC}_{c}$ & Deviance \\
\hline Temperature + Total discharge & 16 & $2,570.27$ & 0.00 & $2,538.04$ \\
\hline Temperature + Spill discharge & 16 & $2,571.48$ & 1.21 & 2,539.25 \\
\hline Temperature + Spill pattern + Total discharge & 21 & $2,573.29$ & 3.02 & $2,530.90$ \\
\hline Temperature + Spill pattern & 20 & $2,575.11$ & 4.84 & $2,534.75$ \\
\hline Temperature + Percent spill & 16 & $2,576.55$ & 6.28 & $2,544.32$ \\
\hline Temperature & 15 & $2,577.33$ & 7.06 & $2,547.13$ \\
\hline Spill discharge & 15 & $2,577.35$ & 7.08 & $2,547.15$ \\
\hline Spill pattern & 19 & $2,578.16$ & 7.89 & $2,539.84$ \\
\hline Spill pattern + Total discharge & 20 & $2,578.49$ & 8.22 & $2,538.14$ \\
\hline Total discharge & 15 & $2,578.69$ & 8.42 & $2,548.49$ \\
\hline Percent spill & 15 & $2,580.22$ & 9.95 & $2,550.02$ \\
\hline Tag burden & 15 & $2,581.26$ & 10.99 & $2,551.05$ \\
\hline Intercept & 14 & $2,581.33$ & 11.06 & $2,553.16$ \\
\hline
\end{tabular}


Table B3. Model selection for fish that passed through the juvenile bypass system outfall at McNary Dam relating survival (ø) as a function of individual and group covariates using the fixed structure of the best model for $p$ and $\lambda$ parameters for subyearling Chinook salmon, 2004-09.

[The best-fit models are indicated in bold. Q, discharge]

\begin{tabular}{|c|c|c|c|c|}
\hline Model & $\begin{array}{l}\text { Number of } \\
\text { parameters }\end{array}$ & $\mathrm{AIC}_{c}$ & $\Delta \mathrm{AlC}_{c}$ & Deviance \\
\hline Temperature + Spill pattern + Fish weight + Total Q + Spill pattern*Total $\mathbf{Q}^{1}$ & 26 & $4,062.74$ & 0.00 & $4,010.28$ \\
\hline Temperature + Spill pattern + Total Q + Spill pattern*Total Q & 25 & $4,063.24$ & 0.50 & $4,012.81$ \\
\hline Temperature + Spill pattern + Fish weight & 20 & $4,065.41$ & 2.67 & $4,025.13$ \\
\hline Temperature + Spill pattern & 19 & $4,066.09$ & 3.35 & $4,027.84$ \\
\hline Temperature + Fish weight & 15 & $4,067.41$ & 4.67 & $4,037.25$ \\
\hline Temperature & 14 & $4,067.56$ & 4.82 & $4,039.43$ \\
\hline Total Q & 14 & $4,087.62$ & 24.88 & $4,059.48$ \\
\hline Spill pattern + Total Q + Spill pattern*Total Q & 24 & $4,090.14$ & 27.40 & $4,041.75$ \\
\hline Spill Pattern + Total Q & 19 & $4,091.10$ & 28.36 & $4,052.85$ \\
\hline Spill pattern & 18 & $4,097.98$ & 35.24 & $4,061.76$ \\
\hline Percent spill & 14 & $4,105.97$ & 43.23 & $4,077.83$ \\
\hline Turbine discharge & 14 & $4,118.08$ & 55.34 & $4,089.94$ \\
\hline Intercept & 13 & $4,119.27$ & 56.53 & $4,093.15$ \\
\hline
\end{tabular}

${ }^{1}$ Addition of year to this model decreased $\mathrm{AIC}_{\mathrm{c}}$ by 2.39 . 
This page left intentionally blank 
Publishing support provided by the U.S. Geological Survey

Publishing Network, Tacoma Publishing Service Center

For more information concerning the research in this report, contact the Director, Western Fisheries Research Center

U.S. Geological Survey

6505 NE 65th Street

Seattle, WA 98115

http://wfrc.usgs.gov/ 


\section{㞭}

竞

疍 